\title{
DOE/NV/11718-985
}

\section{ECOLOGICAL MONITORING AND COMPLIANCE PROGRAM FISCAL/CALENDAR YEAR 2004 REPORT}

\section{March 2005}

\section{Prepared by}

Bechtel Nevada Ecological Services

P.O. Box 98521 1. L Las Vegas, NV 89193-8521 


\section{DISCLAIMER STATEMENT}

Reference herein to any specific commercial product, process, or service by trade name, trademark, manufacturer, or otherwise, does not necessarily constitute or imply its endorsement, recommendation, or favoring by the U.S. Government or any agency thereof or its contractors or subcontractors.

\section{AVAILABILITY STATEMENT}

Available for sale to the public from:

U.S. Department of Commerce

National Technical Information Service

5285 Port Royal Road

Springfield, VA 22161-0002

Telephone: 800-553-6847

Fax: 703-605-6900

E-mail: orders@ntis.gov

Online ordering: http://www.ntis.gov/ordering.htm

Available electronically at http://www.osti.gov/bridge

Available for a processing fee to the U.S. Department of Energy and its contractors, in paper, from:

U.S. Department of Energy

Office of Scientific and Technical Information

P.O. Box 62

Oak Ridge, TN 37831-0062

Telephone: 865-576-8401

Fax: 865-576-5728

E-Mail: reports@adonis.osti.gov 


\title{
ECOLOGICAL MONITORING AND COMPLIANCE PROGRAM FISCAL/CALENDAR YEAR 2004 REPORT
}

March 2005

\author{
WORK PERFORMED UNDER \\ CONTRACT NO. DE-AC08-96NV11718 \\ Prepared for the \\ U.S. Department of Energy \\ National Nuclear Security Administration \\ Nevada Site Office \\ Environment, Safety and Health Division \\ P.O. Box 98518 \\ Las Vegas, NV 89193-8518
}

Prepared by

\section{Bechtel Nevada}

Ecological Services

P.O. Box 98521

Las Vegas, NV 89193-8521 
THIS PAGE IS INTENTIONALLY LEFT BLANK 


\section{CONTENTS}

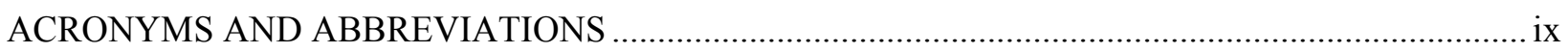

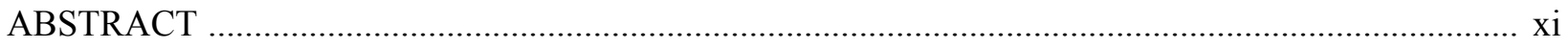

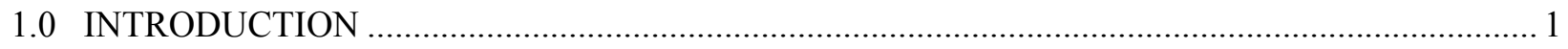

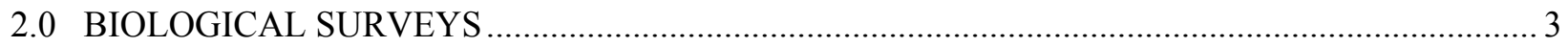

2.1 Sites Surveyed and Sensitive and Protected/Regulated Species Observed ........................... 3

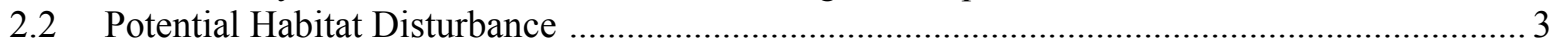

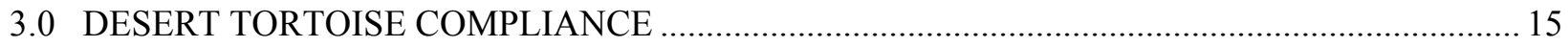

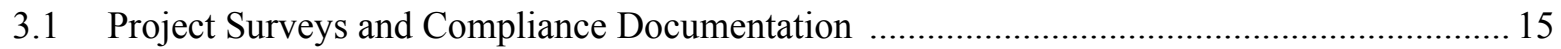

3.2 Habitat Revegetation Plan for Loss of Tortoise Habitat ..................................................... 18

3.3 Coordination With Other Wildlife Agencies/Biologists ...................................................... 19

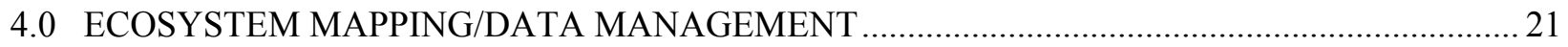

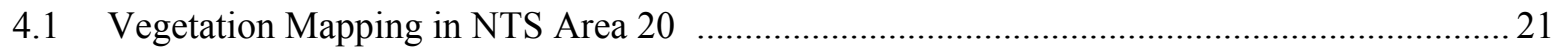

4.2 Sampling of Selected ELUs for Canopy Cover Data ....................................................... 21

4.3 Vegetation Survey for Determining Wildland Fire Hazards .............................................. 23

4.4 Coordination With Ecosystem Management Agencies and Scientists ................................. 26

5.0 SENSITIVE SPECIES AND HABITAT MONITORING ….................................................... 27

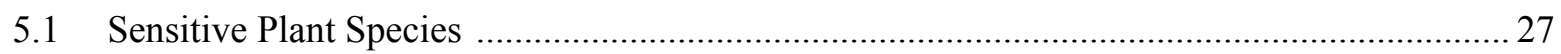

5.1.1 Revised List of Sensitive Plant Species of the NTS ............................................ 27

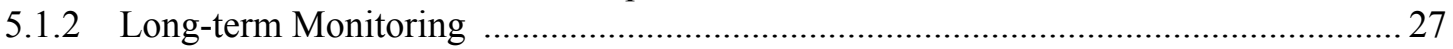

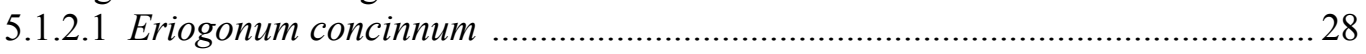

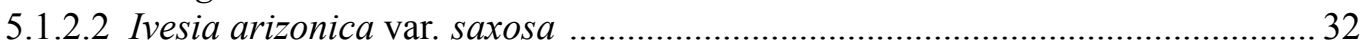

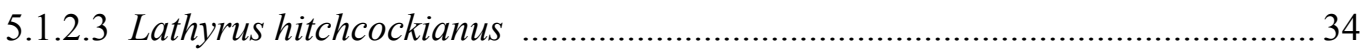

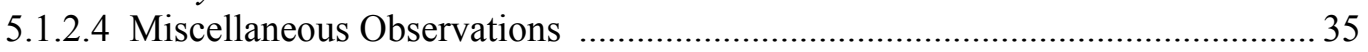

5.1.3 Coordination With Natural Resource Agency Botanists ........................................ 36

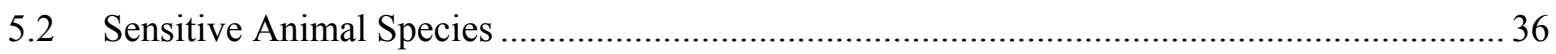

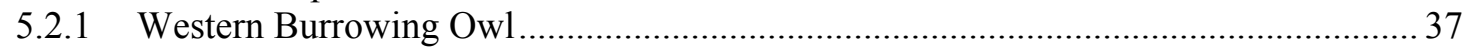

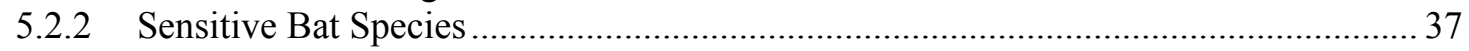

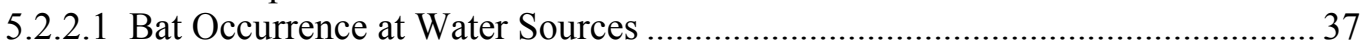

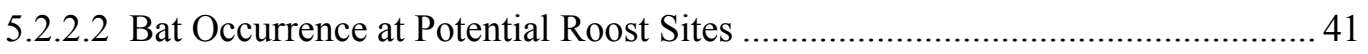

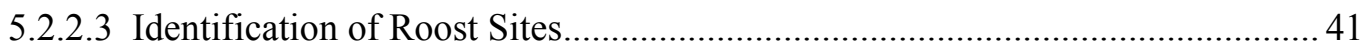

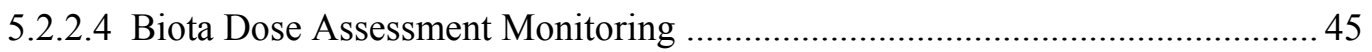

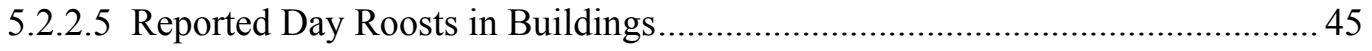

5.2.2.6 Passive Acoustic Monitoring System ............................................................... 45

5.2.2.7 Coordination With Other Wildlife Agencies/Biologists .................................... 48

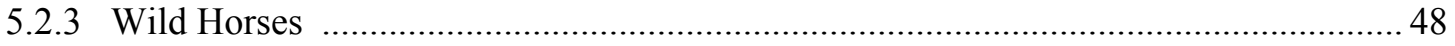

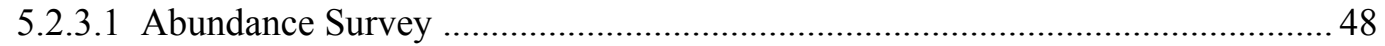

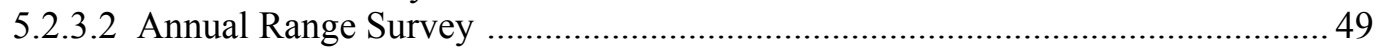

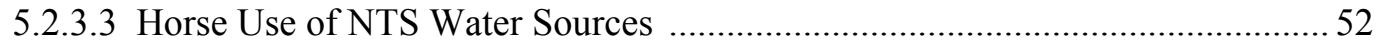




\section{CONTENTS}

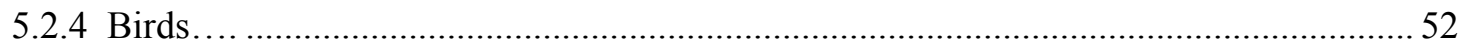

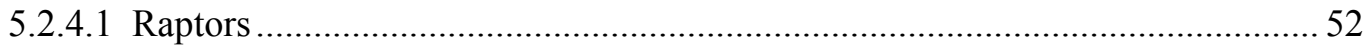

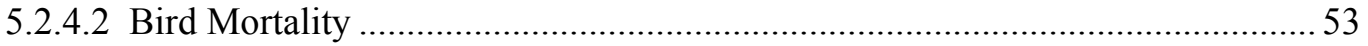

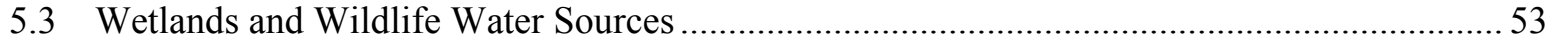

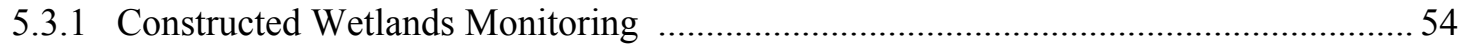

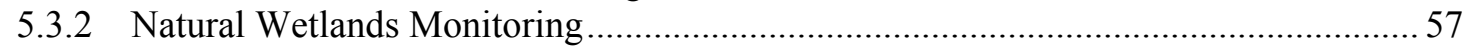

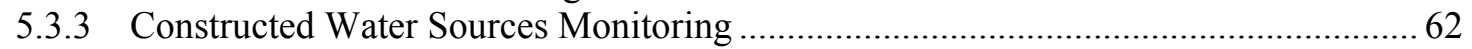

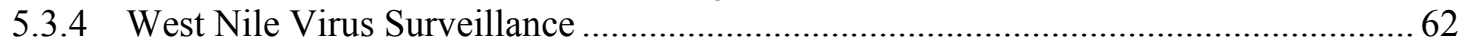

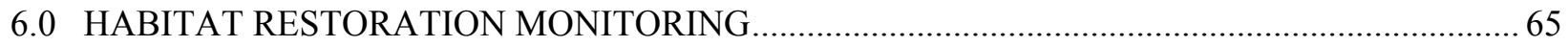

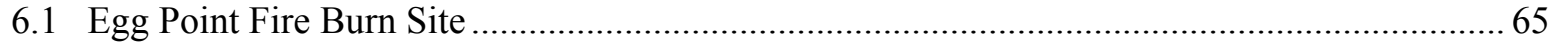

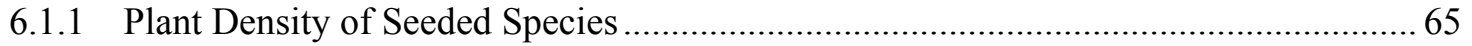

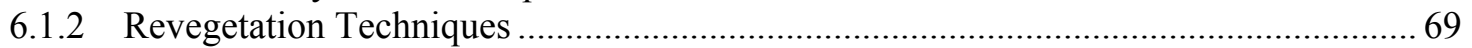

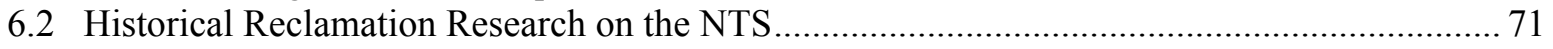

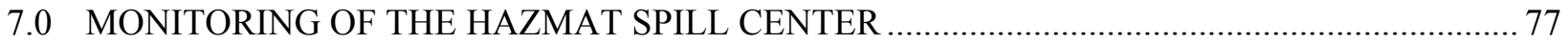

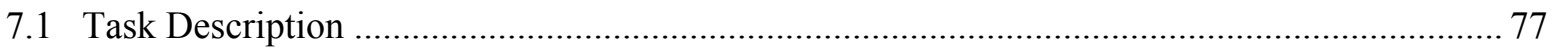

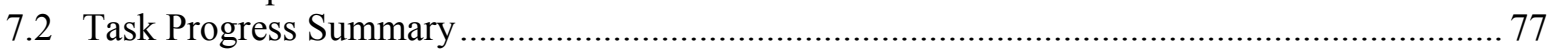

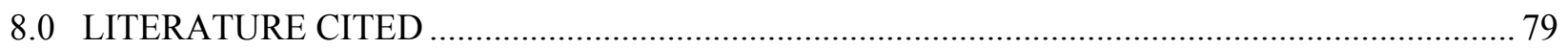

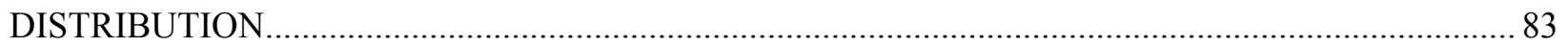

\section{List of Tables}

Table 2-1. List of sensitive and protected/regulated species known to occur on or adjacent to the NTS.... 4

Table 2-2. Summary of biological surveys conducted on the NTS during FY/CY 2003 ........................ 9

Table 2-3. Total area (ha) proposed for disturbance within important habitats in FY/CY 2004

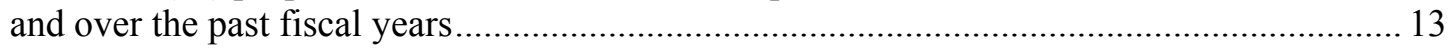

Table 3-1. Summary of tortoise compliance activities conducted by BN biologists

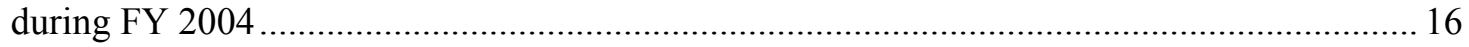

Table 3-2. Parameters and threshold values for desert tortoise monitoring on the NTS ........................ 18

Table 5-1. Characteristics of Eriogonum concinnum habitat on the NTS ............................................ 31

Table 5-2. Characteristics of Ivesia arizonica var. saxosa habitat on the NTS ...................................... 33

Table 5-3. Characteristics of Lathryus hitchcockianus habitat on or near the NTS .................................34 
Table 5-4. Number of bats captured by sex and reproductive condition and number of electronic files of bat calls at water sources monitored in FY/CY 2004.

Table 5-5. Number of bats captured by sex and reproductive condition and number of electronic files of bat calls at potential roost sites monitored in FY/CY 2004

Table 5-6. Bat use designations for all potential roost sites monitored during FY/CY 2004.

Table 5-7. Number of horse individuals observed on the NTS by age class, gender, and year since 1995 .

Table 5-8. Records of migratory bird mortality on the NTS FY/CY 2004. .53

Table 5-9. Description of constructed wetlands on Frenchman Lake characterized in FY/CY 2004........ 56

Table 5-10. Hydrology data from natural water sources on the NTS collected during FY/CY 2004........ 58

Table 5-11. Wildlife observed at selected NTS natural water sources during FY/CY 2004. 60

Table 6-1. Perennial plant densities on the upper and lower slopes of the Egg Point Fire restoration site..

Table 6-2. Perennial plant densities on areas hand-seeded and mechanically-seeded on the Egg Point Fire restoration site..... .72

Table 6-3. Historical revegetation sites located in 2004 to be sampled in future years. .74

Table 6-4. Historical revegetation sites not located in 2004 or found to have been disturbed and not to be sampled in future years .75

\section{List of Figures}

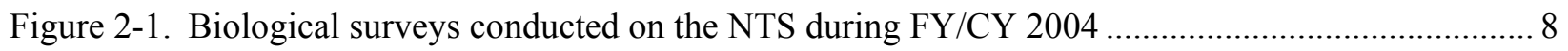

Figure 2-2. Biological surveys conducted in important habitats of the NTS during FY/CY 2004 ............ 14

Figure 3-1. Biological surveys conducted in desert tortoise habitat on the NTS in FY/CY 2004 ............ 18

Figure 4-1. Portions of NTS Area 20 where vegetation was mapped in FY/CY 2004 ........................ 21

Figure 4-2. Wildland fire hazard assessment sites on the NTS by hazard class in FY/CY 2004 ...........24

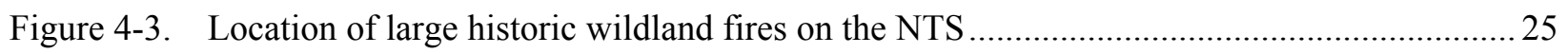

Figure 5-1. Eriogonum concinnum growing in tuffaceous soils near Silent Canyon in Area 19 of the NTS 
Figure 5-2. Sensitive plant populations monitored on or near the NTS during FY/CY 2004................ 30

Figure 5-3. Typical habitat of E. concinnum south of Pinyon Butte .................................................. 31

Figure 5-4. Ivesia arizonica var. saxosa growing in cracks of boulders in Columbine Canyon ............... 32

Figure 5-5. Loose rocky habitat for Lathryus hitchcockianus near Pinyon Pass just west of

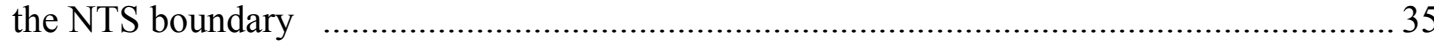

Figure 5-6. Sites monitored for bat activity during FY/CY 2004 .................................................... 38

Figure 5-7. Trends in the age structure of the horse population from 1995 to FY/CY 2004 ..................50

Figure 5-8. Estimated age structure of live horses on the NTS ....................................................... 50

Figure 5-9. Feral horse sightings and horse sign observed on the NTS during FY/CY 2004 ...............51

Figure 5-10. Location of constructed wetlands surveyed in FY/CY 2004 on Frenchman Lake................ 55

Figure 5-11. An example of one of the newly surveyed wetlands on Frenchman Lake ......................... 57

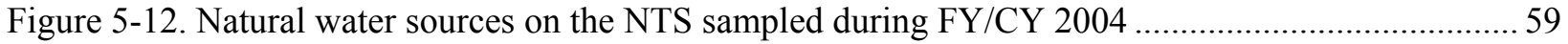

Figure 5-13. Constructed water sources monitored for wildlife use and mortality on the NTS during FY/CY 2004

Figure 6-1. Plant density by lifeform and year on the upper slopes of the Egg Point Fire burn site

Figure 6-2. Young seedlings of Penstemon eatonii, Artemisia nova and Coleogyne ramosissima were common on the upper slopes of the Egg Point Fire burn site

Figure 6-3. Plant density by lifeform and year on the lower slopes of the Egg Point Fire burn site

Figure 6-4. Hand seeding and raking in the seed on the upper slopes of the Egg Point Fire burn site...... 70

Figure 6-5. An all-terrain vehicle with a mechanical seeder attached to the front and drag chains on the back was used to seed the lower slopes and bottom areas of the Egg Point Fire burn site

Figure 6-6. Plant densities on hand-seeded versus mechanically seeded sites .71

Figure 6-7. Location of historical revegetation sites on the NTS .73 


\section{ACRONYMS AND ABBREVIATIONS}

Ac

$\mathrm{BN}$

CAU

$\mathrm{cm}$

CWA

CY

DoD

$\mathrm{DOE} / \mathrm{NV}$

DOQQ

EGIS

ELU

EMAC

ER

ESA

ESHD

$\mathrm{ft}$

FMF

FWS

FY

GIS

GPS

Ha

HSC

in

$\mathrm{km}$

$\mathrm{km}^{2}$

$\mathrm{m}$

$\mathrm{m}^{2}$

mi

$\mathrm{mm}$

Acre

Bechtel Nevada

Corrective Action Unit

Centimeter

Clean Water Act

Calendar Year

U.S. Department of Defense

U.S. Department of Energy, Nevada Operations Office

Digital Orthophoto Quarter Quadrangle

Ecological Geographic Information System

Ecological Landform Unit

Ecological Monitoring and Compliance

Environmental Restoration

Endangered Species Act

Environment, Safety and Health Division

Feet

Frenchman Flat

U.S. Fish and Wildlife Service

Fiscal Year

Geographic Information System

Global Positioning System

Hectare

Hazardous Materials Spill Center

Inch

Kilometer

Square kilometers

Meter

Square meters

Mile

Millimeter 
NAD27

NAD83

NNHP

NNPS

NNSA/NSO

NTS

Opinion

RMP

SWANCC

USACE

USGS

UTM

WNV

yd
North American Datum of 1927

North American Datum of 1983

Nevada Natural Heritage Program

Nevada Native Plant Society

U.S. Department of Energy, National Nuclear Security Administration

Nevada Site Office

Nevada Test Site

U.S. Fish and Wildlife Service Biological Opinion

Resource Management Plan

Solid Waste Agency of Northern Cook County, U.S. Supreme Court No. 99-1178

U.S. Army Corps of Engineers

U.S. Geological Survey

Universal Transverse Mercator

West Nile Virus

Yard

\section{Plant Species Abbreviations}

ACHY

ATCA

ATPO

CORA

ERNA

EPNE

HYSA

KRLA

LATR

LYAN

PRFA

YUBA
Achnatherum hymenoides

Atriplex canescens

Atriplex polycarpa

Coleogyne ramosissima

Ericameria nauseosus

Ephedra nevadensis

Hymenoclea salsola

Krascheninnikovia lanta

Larrea tridentata

Lycium andersonii

Prunus fasciculata

Yucca baccata
Indian ricegrass

fourwing saltbush

cattle saltbush

blackbrush

rubber rabbitbrush

Nevada jointfir

white burrobrush

winterfat

creosote bush

Anderson's wolfberry

desert almond

banana yucca 


\section{ABSTRACT}

The Ecological Monitoring and Compliance program (EMAC), funded through the U.S. Department of Energy, National Nuclear Security Administration Nevada Site Office (NNSA/NSO), monitors the ecosystem of the Nevada Test Site (NTS) and ensures compliance with laws and regulations pertaining to NTS biota. This report summarizes the program's activities conducted by Bechtel Nevada (BN) during the Fiscal Year 2004 and the additional months of October, November, and December 2004, reflecting a change in the monitoring period to a calendar year rather than a fiscal year as reported in the past. This change in the monitoring period was made to better accommodate information required for the NTS Environmental Report, which reports on a calendar year rather than a fiscal year. Program activities included: (1) biological surveys at proposed construction sites, (2) desert tortoise compliance, (3) ecosystem mapping and data management, (4) sensitive species and unique habitat monitoring, (5) habitat restoration monitoring, and (6) biological monitoring at the Hazardous Materials Spill Center (HSC).

Sensitive species of the NTS include 40 plants, 1 mollusk, 1 reptile, over 250 birds, and 23 mammals protected/regulated, managed, or considered sensitive as per state or federal regulations and natural resource agencies and organizations. The threatened desert tortoise is the only species on the NTS protected under the Endangered Species Act. Biological surveys for the presence of sensitive species and important biological resources on which they depend were conducted for 36 projects. A total of 206.74 hectares (ha) (510.86 acres [ac]) and 37 buildings scheduled for demolition were surveyed. Survey findings included: 1 population of Cymopterus ripleyi var. saniculoides; 3 potential tortoise burrows; 5 potential burrowing owl burrows; 27 predator burrows; many Joshua trees and cacti; and 6 bird nests, 1 barn owl, and 1 bat within buildings scheduled for demolition.

Fourteen of the 36 projects were in desert tortoise habitat. NNSA/NSO must comply with the terms and conditions of a permit (called a Biological Opinion) from the U.S. Fish and Wildlife Service (FWS) when conducting work in tortoise habitat. Only $0.20 \mathrm{ha}(0.505 \mathrm{ac})$ of tortoise habitat were disturbed by FY 2004 projects. To date, 87.21 ha $(215.5 \mathrm{ac})$ acres of tortoise habitat have been disturbed on the NTS. No tortoises were found in or displaced from project areas. Two desert tortoises were accidentally killed along paved roads. A draft desert tortoise habitat revegetation plan was submitted this year to the FWS for their approval.

Ecosystem mapping and data management task of EMAC focused on three efforts in FY 2004: (1) updating the vegetation map in Area 20 where new lands were acquired in the northwestern corner of the NTS (a result of NTS boundary changes in October 1999), (2) sampling 68 Ecological Landform Units (ELUs) to obtain estimates of canopy cover of vegetation on ELUs not previously sampled for cover, and (3) vegetation surveys along major NTS corridors to determine wildland fire hazards associated with biomass produced from precipitation received during the spring of 2004. In FY 2004, 221 sites were surveyed for wildland fire hazards. Highest hazards were located in Fortymile Canyon. There has been an average of 6.5 wildland fires per year on the NTS over the past decade with an average of about 396 ha $(980 \mathrm{ac})$ per fire. Areas that were previously burned had increased hazards because of invasive annual grasses that contribute a nearly continuous carpet of fine-textured fuels. Areas reseeded to native perennial species had reduced long-term hazards from wildland fires. Most of the previous burns occurred at mid-elevations in blackbrush vegetation types. Detailed results of the wildland fire hazard survey are described in Hansen and Ostler (2004). 
The annual review of the list of sensitive plants of the NTS was conducted. One vascular plant species was added to the list and four non-vascular plant species were deleted. None of the sensitive plant species known to occur on the NTS are listed by the FWS as endangered or threatened or by the State of Nevada as critically endangered. Currently there are 18 vascular plant species and one non-vascular plant species that are listed as sensitive plant taxa by the Nevada Heritage Program (NNHP) and are known to occur or could potentially occur on the NTS. Three species were monitored in 2004 (Eriogonum concinnum [Darin's buckwheat], Ivesia arizonica var. saxosa [whitefeather ivesia] and Lathyrus hitchcockianus [Hitchcock's peavine]). No apparent threats to the species were noted at any of the sites. Surveys were also made this year of a reported population of Astragalus funereus (black woollypod). It was determined not to occur at this site as had been previously reported. Limited surveys for Eriogonum heermannii var. clokeyi (clokey's buckwheat) were made along Mercury Ridge just north and west of Mercury to become familiar with the habitat of this variety.

Field monitoring of sensitive animals and important habitats of the NTS focused on bats, horses, natural and man-made water sources, and mosquitoes for West Nile Virus (WNV). The list of sensitive bat species was changed to only include high- and moderate-ranked species in the Bat Species Risk Assessment in the Nevada Bat Conservation Plan. Sixty sites were monitored for bat use; 18 were water sources, 41 were potential roost sites, and one site was a ridgeline near a shaft. A total of 120 bats representing 7 sensitive and 2 non-sensitive species were captured, and 3,366 electronic files representing 9 sensitive and 3 non-sensitive species were analyzed. Three maternity roosts were found in mine adits. All three contained Townsend's big-eared bats and two also contained fringed myotis. Six day roosts and 12 night roosts/foraging sites used by multiple species were also identified.

Thirty-seven horses excluding foals were recorded this year during the horse population census compared to 35 seen last year. The horse population showed a small increase in number over last year. Only eight adult males ( $>2$ yrs) were observed among the 33 adult horses counted this year. The herd consists of about 5 horse bands, varying in size from about 5 to 11 individuals in each band. About 30 horses spend their summers west of the Eleana Range, while a much smaller group (7-8 horses) summers in the Eleana Range closer to Yucca Flat. Horses remain highly dependant on Camp 17 and Captain Jack spring for water during summer.

Monitoring of the western burrowing owl was not conducted this year. However, one new burrow site with two burrow openings was found opportunistically in Yucca Flat just south of Sedan Crater. This makes a total of 120 known western burrowing owl locations (30 owl sightings and 90 burrow sites) on the NTS.

No incidents of raptor mortality were reported in FY 2004. Birds were abundant on the NTS in FY 2004, and opportunistic records of birds were recorded throughout the year. There were 19 migratory bird deaths recorded, namely from common species such as Mourning Dove, Chukar, Gambel's Quail, Common Raven, and other passerine species. Uncommon sightings of raptors including a Peregrine Falcon and a Bald Eagle, and of two Phainopeplas were recorded.

Thirty wetlands and 50 man-made water sources were monitored for physical parameters and wildlife use. Signs of horse grazing, trampling of vegetation and presence of horse trails at four natural wetlands was observed, similar to previous years. Over 950 birds representing 40 species of birds were recorded at wetlands this year. Increased numbers of species observed over last year were in part due to increased monitoring effort and improvement of observation techniques. Only two instances of animal mortality (mammals) were recorded in plastic lined sumps this year. 
Eight sites were sampled for mosquitoes to determine if WNV occurs on the NTS. Three mosquitoes captured at Yucca Lake Sewage Lagoons tested negative for the presence of WNV. Mosquitoes captured at Camp 17 Pond, Well C1 Pond, and Well 5B Pond have been submitted for identification and testing. Further monitoring will be conducted next spring through fall.

NTS sites which have been revegetated with native seeds and transplants to control soil erosion, reduce the time-cycle of wildland fires, and reduce the invasion of non-native weed species, are periodically monitored under EMAC. The revegetation success of such sites are documented in order to learn from past methods and to develop better techniques for site restoration. At the Egg Point Fire burn site, line transects were sampled and the density of seeded species was 1.88 plants $/ \mathrm{m}^{2}$ (plants per square meter) on upper slopes and 0.87 plants $/ \mathrm{m}^{2}$ on lower slopes.

Over the past several decades various reclamation research trials have been conducted on the NTS to evaluate different reclamation techniques or to test the performance of certain plant species in this environment. Twenty-eight such trial sites were evaluated this year to determine which sites still existed and if sampling the site would provide information on the success of reclamation techniques or plant performance. Fifteen of the sites were located and will be monitored in future years as time and funding allow. Chemical release test plans for five activities at the HSC on Frenchman Lake playa were reviewed. Seasonal sampling of downwind and upwind transects near the spill center was conducted to document baseline conditions of biota. 
THIS PAGE INTENTIONALLY LEFT BLANK 


\subsection{INTRODUCTION}

In accordance to DOE Order 450.1 "Environmental Protection Program", the Environment, Safety, and Health Division (ESHD) of the U.S. Department of Energy, National Nuclear Security Administration Nevada Site Operations Office (NNSA/NSO) requires ecological monitoring and biological compliance support for activities and programs conducted at the Nevada Test Site (NTS). Bechtel Nevada (BN) Ecological Services has implemented the Ecological Monitoring and Compliance program (EMAC) to provide this support. EMAC is designed to ensure compliance with applicable laws and regulations, delineate and define NTS ecosystems, and provide ecological information that can be used to predict and evaluate the potential impacts of proposed projects and programs on those ecosystems.

This report summarizes the program's activities conducted by BN during the Fiscal Year (FY) 2004 and the additional months of October, November, and December of Calendar Year (CY) 2004. This reflects a change in the monitoring period from a fiscal year (past years) reporting to a calendar year (current and future years) reporting. This change in the monitoring period was made to better provide information required for the Nevada Test Site Environmental Report which is based on a calendar year rather than a fiscal year. Monitoring tasked during FY/CY 2004 included six program areas: (1) Biological Surveys, (2) Desert Tortoise Compliance, (3) Ecosystem Mapping/Data Management, (4) Sensitive Species and Habitat Monitoring, (5) Habitat Restoration Monitoring, and (6) HAZMAT Spill Center Monitoring. The following sections of this report describe work performed under these six areas. 
THIS PAGE IS INTENTIONALLY LEFT BLANK 


\subsection{BIOLOGICAL SURVEYS}

Biological surveys are performed at proposed project sites where land disturbance will occur. The goal is to minimize adverse effects of land disturbance on sensitive and protected/regulated plant and animal species (Table 2-1), their associated habitat, and important biological resources. Sensitive species are defined as species that are at risk of extinction or serious decline or whose long-term viability has been identified as a concern. They include species on the Nevada Natural Heritage Program's (NNHP) sensitive plant and animal lists and bat species ranked as moderate or high in the Nevada Bat Conservation Plan Bat Species Risk Assessment. Protected/regulated species are those that are protected or regulated by federal or state law. Many species are both sensitive and protected/regulated (Table 2-1). Important biological resources include such things as cover sites, nest or burrow sites, roost sites, or water sources important to sensitive species. Survey reports are written to document species and resources found and to provide mitigation recommendations.

\subsection{Sites Surveyed and Sensitive and Protected/Regulated Species Observed}

Biological surveys for 42 projects were conducted on or near the NTS (Figure 2-1, Table 2-2). For some of the projects, multiple sites were surveyed (Figure 2-1). A total of 256.2 hectares (ha) (633.0 acres [ac]) was surveyed for the projects (Table 2-2). Twenty three of the projects had sites within the range of the threatened desert tortoise (Gopherus agassizii). Sensitive and protected/regulated species and important biological resources found included: 1 population of Cymopterus ripleyi var. saniculoides; 4 inactive tortoise burrows, 2 kit fox burrows, 2 burrowing owl burrows, 30 predator burrows, mature Joshua trees and cholla cacti; and also 15 bird nests ( 3 active), 1 barn owl, and 1 bat within buildings scheduled for demolition (Table 2-2). BN provided a written summary report of all survey findings and mitigation recommendations, where applicable (Table 2-2). All flagged burrows were avoided during construction activities. All building demolitions were conducted when buildings were confirmed to be empty of bats, active nests, and fledgling or adult birds.

\subsection{Potential Habitat Disturbance}

Surveys are conducted at old industrial or nuclear weapons testing sites whenever vegetation has reinvaded a site or it is suspected that a sensitive or protected/regulated species may be found. For example, tortoises may move through revegetated earthen sumps and may be concealed under vegetation during activities where heavy equipment is used. Preactivity surveys are conducted at such revegetated sites to ensure that they are not in harm's way. Also, burrowing owls frequently inhabit burrows and culverts at disturbed sites, so preactivity surveys are conducted to ensure that adults, eggs, and nestlings in burrows are not harmed.

Eighteen of the projects for which surveys were conducted were entirely on sites previously disturbed (e.g., building sites, industrial waste sites, existing well pads, road shoulders) (Table 2-2). Twenty-four projects were located either partially or entirely in areas that had not been previously disturbed. These projects have the potential to disturb a total of 102.28 ha $(252.74 \mathrm{ac})$. Most of these acres were associated with the Yucca Lake Runway (Project No. 04-08 and 04-19) and the expansion of the gravel pit in Area 6 (Project No. 04-23) (Table 2-2).

Eleven of the projects that will cause new disturbances occurred in areas designated as important habitat (Table 2-3, Figure 2-2). During vegetation mapping of the NTS, Ecological Landform Units (ELUs) were evaluated and some were identified as Pristine (having few human-made disturbances), Unique (containing uncommon biological resources such as a natural wetland), Sensitive (containing vegetation 
associations which recover very slowly from direct disturbance), and Diverse (having high plant species diversity) (DOE/NV, 1998). A single ELU could be classified as more than one type of important habitat. Figure 2-2 shows the distribution of these important habitats which were ranked so that pristine habitat overlays unique, which then overlays sensitive, which then overlays diverse habitat.

Table 2-1. List of sensitive and protected/regulated species known to occur on or adjacent to the NTS.

\begin{tabular}{|c|c|c|}
\hline SENSITIVE PLANT SPECIES & Common Names & Status $^{\mathrm{a}}$ \\
\hline \multicolumn{3}{|l|}{ Flowering Plant Species } \\
\hline Astragalus beatleyae & Beatley's milkvetch & $\mathrm{S}, \mathrm{A}$ \\
\hline Astragalus funereus & Black woollypod & $\mathrm{S}, \mathrm{A}$ \\
\hline Astragalus oopherus var. clokeyanus & Clokey's egg milkvetch & $\mathrm{S}, \mathrm{A}$ \\
\hline Eriogonum concinnum & Darin's buckwheat & $\mathrm{S}, \mathrm{A}$ \\
\hline Eriogonum heermannii var. clokeyi & Clokey's buckwheat & $\mathrm{S}, \mathrm{A}$ \\
\hline Ivesia arizonica var. saxosa & Whitefeather ivesia & $\mathrm{S}, \mathrm{A}$ \\
\hline Lathyrus hitchcockianus & Hitchcock's peavine & $\mathrm{S}, \mathrm{A}$ \\
\hline Phacelia beatleyae & Beatley's phacelia & $\mathrm{S}, \mathrm{A}$ \\
\hline Arctomecon merriamii & White bearpoppy & $\mathrm{S}, \mathrm{IA}$ \\
\hline Camissonia megalantha & Cane Spring suncup & S, IA \\
\hline Cymopterus ripleyi var. saniculoides & Ripley's springparsley & $\mathrm{S}, \mathrm{IA}$ \\
\hline Frasera pahutensis & Pahute green gentian or Modoc elkweed & $\mathrm{S}, \mathrm{IA}$ \\
\hline Galium hilendiae ssp. kingstonense & Kingston Mountain bedstraw & S, IA \\
\hline Hulsea vestita $\mathrm{ssp}$. inyoensis & Inyo hulsea & $\mathrm{S}, \mathrm{IA}$ \\
\hline Penstemon pahutensis & Pahute penstemon & S, IA \\
\hline Phacelia mustelina & Weasel phacelia & $\mathrm{S}, \mathrm{IA}$ \\
\hline Phacelia parishii & Parish's phacelia & $\mathrm{S}, \mathrm{IA}$ \\
\hline Sclerocactus polyancistrus & Hermit cactus & $\mathrm{CY}, \mathrm{S}, \mathrm{IA}$ \\
\hline \multicolumn{3}{|l|}{ Moss Species } \\
\hline Entosthodon planoconvexus & Planoconvex enthosthodon & $\mathrm{S}, \mathrm{E}$ \\
\hline \multicolumn{3}{|l|}{ PROTECTED/REGULATED PLANT SPECIES } \\
\hline Cactaceae & Cacti (16 species) & $\mathrm{CY}$ \\
\hline Agavaceae & Yucca (3 species) & $\mathrm{CY}$ \\
\hline Pinus monophylla/Juniperus osteosperma & Pinyon/Juniper & CY \\
\hline
\end{tabular}


Table 2-1 Continued

\begin{tabular}{|c|c|c|}
\hline SENSITIVE ANIMAL SPECIES & Common Name & Status $^{\mathrm{a}}$ \\
\hline \multicolumn{3}{|l|}{ Mollusk Species } \\
\hline Pyrgulopsis turbatrix & Southeast Nevada springsnail & $\mathrm{S}, \mathrm{A}$ \\
\hline \multicolumn{3}{|l|}{ Reptile Species } \\
\hline Eumeces gilberti rubricaudatus & Western red-tailed skink & $\mathrm{S}, \mathrm{E}$ \\
\hline Gopherus agassizii & Desert tortoise & LT, S, NP, IA \\
\hline \multicolumn{3}{|l|}{ Bird Species } \\
\hline Accipiter gentilis & Northern goshawk & $\mathrm{S}, \mathrm{NP}, \mathrm{IA}$ \\
\hline Athene cunicularia hypugea & Western burrowing owl & $\mathrm{S}, \mathrm{NP}, \mathrm{A}$ \\
\hline Buteo regalis & Ferruginous hawk & $\mathrm{S}, \mathrm{NP}, \mathrm{IA}$ \\
\hline B. swainsoni & Swainson's hawk & $\mathrm{S}, \mathrm{NP}, \mathrm{A}$ \\
\hline Chlidonias niger & Black tern & $\mathrm{S}, \mathrm{NP}, \mathrm{IA}$ \\
\hline Coccyzus americanus & Western yellow-billed cuckoo & S, IA \\
\hline Falco peregrinus anatum & American peregrine falcon & $<\mathrm{LE}, \mathrm{S}, \mathrm{NP}, \mathrm{IA}$ \\
\hline Gavia immer & Common loon & S, IA \\
\hline Haliaeetus leucocephalus & Bald eagle & LT-PD, EA, S, NP, IA \\
\hline Ixobrychus exillis hesperis & Western least bittern & $\mathrm{S}, \mathrm{NP}, \mathrm{IA}$ \\
\hline Phainopepla nitens & Phainopepla & $\mathrm{S}, \mathrm{NP}, \mathrm{IA}$ \\
\hline Plegadis chihi & White-faced ibis & $\mathrm{S}, \mathrm{NP}, \mathrm{IA}$ \\
\hline \multicolumn{3}{|l|}{ Mammal Species } \\
\hline Antrozous pallidus & Pallid bat & $\mathrm{M}, \mathrm{A}$ \\
\hline Corynorhinus townsendii pallescens & Townsend's big-eared bat & $\mathrm{H}, \mathrm{A}$ \\
\hline Euderma maculatum & Spotted bat & $\mathrm{M}, \mathrm{NP}, \mathrm{A}$ \\
\hline Lasionycteris noctivagans & Silver-haired bat & $\mathrm{M}, \mathrm{A}$ \\
\hline Lasiurus blossevillii & Western red bat & $\mathrm{H}, \mathrm{A}$ \\
\hline
\end{tabular}




\begin{tabular}{lll} 
Table 2-1 Continued & Common Name & Status $^{\mathbf{a}}$ \\
\hline \hline Lasiurus cinereus & Hoary bat & $\mathrm{M}, \mathrm{A}$ \\
Myotis californicus & California myotis & $\mathrm{M}, \mathrm{A}$ \\
Myotis ciliolabrum & Small-footed myotis & $\mathrm{M}, \mathrm{A}$ \\
Myotis evotis & Long-eared myotis & $\mathrm{M}, \mathrm{A}$ \\
Myotis thysanodes & Fringed myotis & $\mathrm{H}, \mathrm{A}$ \\
Myotis yumanensis & Yuma myotis & $\mathrm{M}, \mathrm{A}$ \\
Pipistrellus hesperus & Western pipistrelle & $\mathrm{M}, \mathrm{A}$ \\
& & \\
\hline \hline
\end{tabular}

PROTECTED/REGULATED ANIMAL SPECIES

\section{Bird Species ${ }^{\mathrm{b}}$}

\begin{tabular}{llc}
\hline Alectoris chukar & Chukar & $\mathrm{G}$ \\
Aquila chrysaetos & Golden Eagle & EA, NP \\
Callipepla gambelii & Gambel's Quail & $\mathrm{G}$ \\
Charadrius montanus & Mountain Plover & PT
\end{tabular}

\section{Mammal Species}

\begin{tabular}{lll}
\hline Antilocapra americana & Pronghorn antelope & $\mathrm{G}$ \\
Equus asinus & Burro & H\&B \\
Equus caballus & Horse & H\&B \\
Felis concolor & Mountain lion & $\mathrm{G}$ \\
Lynx rufus & Bobcat & $\mathrm{F}$ \\
Ovis canadensis nelsoni & Desert bighorn sheep & $\mathrm{G}$ \\
Odocoileus hemionus & Mule deer & $\mathrm{G}$ \\
Sylvilagus audubonii & Audubon's cottontail & $\mathrm{G}$ \\
Sylvilagus nuttallii & Nuttall's cottontail & $\mathrm{G}$ \\
Urocyon cinereoargenteus & Gray fox & $\mathrm{F}$ \\
Vulpes velox macrotis & Kit fox & $\mathrm{F}$ \\
\hline \hline $\begin{array}{l}\text { Status Codes: } \\
\text { Endangered Species Act, U.S. Fish and Wildlife Service }\end{array}$ & \\
\hline $\begin{array}{l}\text { LT - Listed Threatened } \\
\text { PD - Proposed for listing as Threatened }\end{array}$ & & \\
$<$ LE - Former listed endangered species & &
\end{tabular}




\section{Table 2-1 Continued - Footnotes}

U.S. Department of Interior

H\&B - Protected under Wild Free Roaming Horses and Burros Act

EA - Protected under Bald and Golden Eagle Act

State of Nevada-Animals

S - Nevada Natural Heritage Program-Sensitive Animal Taxa

NP - Species protected under NRS 501

$\mathrm{G}$ - Regulated as game species

F - Regulated as fur-bearer species

State of Nevada-Plants

S - Nevada Natural Heritage Program-Sensitive Plant Taxa

CY - Protected as a cactus, yucca, or Christmas tree

Long-term Monitoring Status for Nevada Test Site (NTS) (see Section 5.0 of this report)

A - Active

IA - Inactive

E - Evaluate

Nevada Bat Conservation Plan - Bat Species Risk Assessment

$\mathrm{H}$ - High

M - Moderate

b All bird species on the NTS are protected by the Migratory Bird Treaty Act except for Chukar, Gambel's quail, English house sparrow, Rock dove, and European starling. 


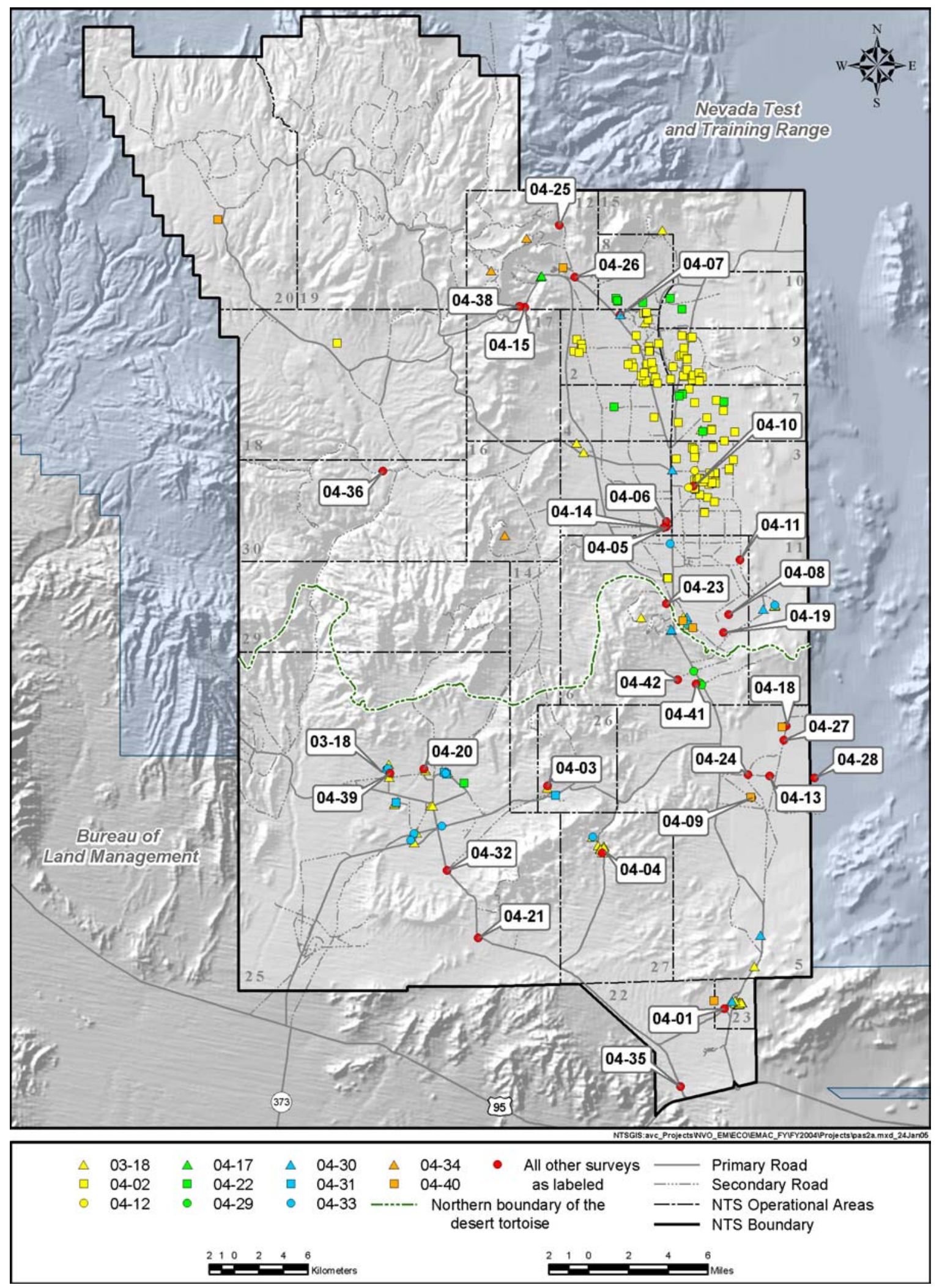

Figure 2-1. Biological surveys conducted on the NTS during FY/CY 2004. 
Table 2-2. Summary of biological surveys conducted on the NTS during FY/CY 2004.

\begin{tabular}{|c|c|c|c|c|c|}
\hline $\begin{array}{l}\text { Project } \\
\text { No. }\end{array}$ & Project & $\begin{array}{l}\text { Important } \\
\text { Species/ Resources } \\
\text { Found }\end{array}$ & $\begin{array}{c}\text { Area } \\
\text { Surveyed } \\
\text { ha (acres) }\end{array}$ & $\begin{array}{c}\text { Proposed Project } \\
\text { Area in } \\
\text { Undisturbed } \\
\text { Habitat in ha (acres) }\end{array}$ & $\begin{array}{c}\text { Mitigation } \\
\text { Recommendations }\end{array}$ \\
\hline $03-18^{\mathrm{a}}$ & Building demolitions (24 buildings) & $\begin{array}{l}6 \text { empty passerine bird nests, } \\
2 \text { passerine bird nests with eggs, } \\
1 \text { nest with } 4 \text { nestlings }\end{array}$ & 0 & 0 & $\begin{array}{l}\text { Postpone demolition until eggs } \\
\text { have hatched and nestlings have } \\
\text { fledged. (Empty nests were } \\
\text { removed). }\end{array}$ \\
\hline 04-01 & $\begin{array}{l}\text { Barbed wire cleanup on Jackass Flats Road } \\
\text { (1 site) }\end{array}$ & Active predator burrow & $\begin{array}{r}1.50 \\
(3.71)\end{array}$ & $0.14(0.34)$ & Avoid flagged predator burrow \\
\hline 04-02 & Borehole Management (108 sites) & $\begin{array}{l}\text { Potential burrowing owl burrows } \\
\text { (culverts) at } 2 \text { sites, regrowth of native } \\
\text { vegetation at } 4 \text { sites }\end{array}$ & $\begin{array}{l}31.61 \\
(78.11)\end{array}$ & 0 & $\begin{array}{l}\text { Avoid disturbing human-made } \\
\text { culverts and native vegetation } \\
\text { regrowth }\end{array}$ \\
\hline 04-03 & Horn Silver Mine $\left(\mathrm{CAU}^{\mathrm{b}}\right.$ 527) (1 site) & None & $0.97(2.40)$ & $0.47(1.17)$ & None \\
\hline 04-04 & $\begin{array}{l}\text { Area 25, 26, and } 27 \text { Septic Systems (CAU 271) } \\
\text { (1 site) }\end{array}$ & None & $\begin{array}{c}0.08 \\
(0.20)\end{array}$ & 0 & Do not drive in adjacent wash \\
\hline 04-05 & U1a Leachfield (1 site) & 5 predator burrows, Joshua tree & $\begin{array}{c}1.15 \\
(2.84)\end{array}$ & 0 & $\begin{array}{l}\text { Avoid flagged predator burrows and } \\
\text { Joshua tree }\end{array}$ \\
\hline 04-06 & U1h Leachfield (1 site) & None & $0.39(0.96)$ & 0 & None \\
\hline 04-07 & Cleanup of Area 2 Bit Cutters Yard (1 site) & 1 predator burrow, cholla cacti & $\begin{array}{c}5.67 \\
(13.89)\end{array}$ & 0 & $\begin{array}{l}\text { Avoid flagged predator burrow and } \\
\text { cholla cacti }\end{array}$ \\
\hline 04-08 & Yucca Lake Runway Project (1 site) & None & $\begin{array}{l}26.00 \\
(64.25)\end{array}$ & $8.54(21.10)$ & None \\
\hline 04-09 & Landfills (CAU 5) (1 site) & None & $0.29(0.72)$ & $0.03(0.07)$ & None \\
\hline $04-10$ & Area 3 Release Site (CAU 536) (1 site) & None & $0.35(0.86)$ & 0 & None \\
\hline $04-11$ & ER-6-1 Poleline Installation (1 site) & Joshua trees & $\begin{array}{c}4.16 \\
(10.29)\end{array}$ & $0.65(1.61)$ & Avoid Joshua trees \\
\hline
\end{tabular}


Table 2-2. (Continued)

\begin{tabular}{|c|c|c|c|c|c|}
\hline $\begin{array}{l}\text { Project } \\
\text { Number }\end{array}$ & Project & $\begin{array}{l}\text { Important } \\
\text { Species/ Resources } \\
\text { Found }\end{array}$ & $\begin{array}{l}\text { Area } \\
\text { Surveyed } \\
\text { in ha } \\
\text { (acres) }\end{array}$ & $\begin{array}{c}\text { Proposed Project } \\
\text { Area in } \\
\text { Undisturbed } \\
\text { Habitat in ha } \\
\text { (acres) }\end{array}$ & $\begin{array}{c}\text { Mitigation } \\
\text { Recommendations }\end{array}$ \\
\hline 04-12 & $\begin{array}{l}\text { Areas } 1 \text { and } 3 \text { Release Sites and Injection Wells } \\
\text { (CAU 322) (2 sites) }\end{array}$ & None & $\begin{array}{c}0.49 \\
(1.21)\end{array}$ & 0 & None \\
\hline 04-13 & 5-07 Road Repair (1 site) & None & $\begin{array}{c}1.50 \\
(3.71)\end{array}$ & $0.10(0.25)$ & None \\
\hline 04-14 & Waterline from Well 3 to U1gh (1 site) & $\begin{array}{l}\text { Cymopterus ripleyi var. } \\
\text { saniculoides plants, inactive } \\
\text { predator burrows }\end{array}$ & $\begin{array}{c}4.00 \\
(9.83)\end{array}$ & $1.38(3.41)$ & $\begin{array}{l}\text { Avoid flagged areas where } C \text {. ripleyi } \\
\text { var. saniculoides plants occur and } \\
\text { predator burrows }\end{array}$ \\
\hline $04-15$ & Stockade Wash Road Gravel Pit (1 site) & None & $\begin{array}{c}0.30 \\
(0.74)\end{array}$ & $0.30(0.74)$ & None \\
\hline $04-16^{\mathrm{c}}$ & $\begin{array}{l}\text { CNTA Hydrologic Monitoring Wells (CAU 443) } \\
\text { ( } 2 \text { sites) }\end{array}$ & $\begin{array}{l}\text { Cholla cacti within both } \\
\text { proposed well pad sites }\end{array}$ & $\begin{array}{c}4.25 \\
(10.5)\end{array}$ & $4.25(10.5)$ & $\begin{array}{l}\text { Avoid cholla cactus or salvage and } \\
\text { replant them following pad } \\
\text { construction }\end{array}$ \\
\hline 04-17 & $\begin{array}{l}\text { Cleanup of Rainier Mesa Substation (1 site, } 1 \\
\text { building) }\end{array}$ & None & $\begin{array}{l}1.20 \\
(2.96)\end{array}$ & 0 & None \\
\hline 04-18 & $\begin{array}{l}\text { Soil Stockpile and Parking Lot Construction for } \\
\text { Disposal Cells } 14 \text { and } 15 \text { ( } 2 \text { sites })\end{array}$ & 4 predator burrows & $\begin{array}{c}13.90 \\
(34.34)\end{array}$ & $11.10(27.43)$ & Avoid flagged burrows \\
\hline 04-19 & Yucca Lake Air Field Improvements (1 site) & $\begin{array}{l}12 \text { active predator burrows, } \\
\text { several yuccas and cacti }\end{array}$ & $\begin{array}{c}28.30 \\
(69.93)\end{array}$ & $26.90(66.47)$ & $\begin{array}{l}\text { Avoid flagged predator burrows, } \\
\text { yucca, and cacti }\end{array}$ \\
\hline $04-20$ & $\begin{array}{l}\text { Area } 25 \text { Contaminated Materials (CAU 529) } \\
\text { (4 sites) }\end{array}$ & None & $\begin{array}{c}1.20 \\
(2.96)\end{array}$ & $0.23(0.57)$ & None \\
\hline $04-21$ & Jackass Flats Road Cleanup (1 site) & 1 inactive tortoise burrow & $\begin{array}{c}0.43 \\
(1.06)\end{array}$ & $0.09(0.22)$ & Avoid possible tortoise burrow \\
\hline 04-22 & Mud Pits and Waste Dump (CAU 357) (11 sites) & $\begin{array}{l}2 \text { kit fox burrows, } 2 \text { predator } \\
\text { burrows }\end{array}$ & $\begin{array}{c}2.13 \\
(5.27)\end{array}$ & 0 & $\begin{array}{l}\text { Avoid kit fox burrows and predator } \\
\text { burrows }\end{array}$ \\
\hline
\end{tabular}


Table 2-2. (Continued)

\begin{tabular}{|c|c|c|c|c|c|}
\hline $\begin{array}{l}\text { Project } \\
\text { Number }\end{array}$ & Project & $\begin{array}{l}\text { Important } \\
\text { Species/ Resources } \\
\text { Found }\end{array}$ & $\begin{array}{l}\text { Area } \\
\text { Surveyed } \\
\text { in ha } \\
\text { (acres) }\end{array}$ & $\begin{array}{c}\text { Proposed Project } \\
\text { Area in } \\
\text { Undisturbed } \\
\text { Habitat in ha } \\
\text { (acres) }\end{array}$ & $\begin{array}{c}\text { Mitigation } \\
\text { Recommendations }\end{array}$ \\
\hline $04-23$ & Area 6 Gravel Pit (1 site) & $\begin{array}{l}1 \text { predator burrow, several } \\
\text { Joshua trees and cacti }\end{array}$ & $\begin{array}{c}38.92 \\
(96.17)\end{array}$ & $36.97(91.35)$ & $\begin{array}{l}\text { Avoid predator burrow, Joshua trees, } \\
\text { and cacti }\end{array}$ \\
\hline $04-24$ & 5-07 Road Cleanup (1 site) & None & $\begin{array}{c}1.12 \\
(0.05)\end{array}$ & 0 & None \\
\hline $04-25$ & P Tunnel Cleanup (1 site) & Yuccas, cacti & $\begin{array}{c}4.48 \\
(11.07)\end{array}$ & $2.34(5.78)$ & Avoid yuccas and cacti \\
\hline $04-26$ & 12-01 Road Cleanup (1 site) & None & $\begin{array}{c}0.01 \\
(0.03)\end{array}$ & 0 & None \\
\hline $04-27$ & $\begin{array}{l}\text { Office/Parking Space Additions at RWMC } \\
\text { (1 site) }\end{array}$ & None & $\begin{array}{l}3.20 \\
(7.91)\end{array}$ & $1.90(4.67)$ & None \\
\hline $04-28$ & Hazmat Buried Object Detection (1 site) & None & $0.6(1.51)$ & $0.61(1.51)$ & None \\
\hline $04-29$ & $\begin{array}{l}\text { National Center for Combating Terrorism (NCCT) } \\
\text { Area } 6 \text { Infrastructure Improvements - }(2 \text { sites })\end{array}$ & $\begin{array}{l}2 \text { inactive tortoise burrows } \\
1 \text { predator burrow, several } \\
\text { Joshua trees }\end{array}$ & $\begin{array}{l}18.90 \\
(21.99)\end{array}$ & $1.64(4.06)$ & Avoid flagged predator burrow \\
\hline $04-30$ & $\begin{array}{l}\text { Decon Pads and Septic Systems (CAU 224) } \\
\text { (9 sites) }\end{array}$ & None & $\begin{array}{c}7.01 \\
(17.32)\end{array}$ & $1.00(2.47)$ & None \\
\hline $04-31$ & CAU 300 (4 sites) & None & $\begin{array}{c}0.74 \\
(1.82)\end{array}$ & 0 & None \\
\hline $04-32$ & Jackass Flats Road Grading & None & $\begin{array}{c}0.20 \\
(0.49)\end{array}$ & 0 & None \\
\hline $04-33$ & Building Demolition (12 buildings) & $\begin{array}{l}6 \text { empty nests, } 1 \text { barn owl, } \\
1 \text { bat }\end{array}$ & 0 & 0 & $\begin{array}{l}\text { Demolish buildings before February } \\
2005 \text { to avoid reuse of nests in the } \\
\text { spring }\end{array}$ \\
\hline $04-34$ & Rainer Mesa/Shoshone Mtn. Drill Sites & None & $\begin{array}{c}11.79 \\
(29.13)\end{array}$ & $2.52(6.23)$ & None \\
\hline
\end{tabular}


Table 2-2. (Continued)

\begin{tabular}{|c|c|c|c|c|c|}
\hline $\begin{array}{l}\text { Project } \\
\text { Number }\end{array}$ & Project & $\begin{array}{c}\text { Important } \\
\text { Species/ Resources } \\
\text { Found }\end{array}$ & $\begin{array}{c}\text { Area } \\
\text { Surveyed } \\
\text { in ha } \\
\text { (acres) }\end{array}$ & $\begin{array}{c}\text { Proposed Project } \\
\text { Area in } \\
\text { Undisturbed } \\
\text { Habitat in ha } \\
\text { (acres) }\end{array}$ & $\begin{array}{c}\text { Mitigation } \\
\text { Recommendations }\end{array}$ \\
\hline $04-35$ & NRDS Road Repair & None & $\begin{array}{c}1.04 \\
(2.57)\end{array}$ & 0 & None \\
\hline $04-36$ & Cat Canyon Road/Pad & 2 predator burrows & $\begin{array}{c}1.40 \\
(3.46)\end{array}$ & $\begin{array}{c}0.35 \\
(0.86)\end{array}$ & Avoid flagged burrow \\
\hline $04-38$ & CAU 552 G Tunnel Tailings & 1 predator burrow & $\begin{array}{l}1.07 \\
(2.6)\end{array}$ & 0 & Avoid flagged burrow \\
\hline 04-39 & CAU 165 Engine Test Stand & None & $\begin{array}{c}1 \\
(2.54)\end{array}$ & $\begin{array}{c}0.19 \\
(0.47)\end{array}$ & None \\
\hline $04-40$ & CAU 5 Landfills (6 sites) & None & $\begin{array}{c}22.36 \\
(55.25)\end{array}$ & 0 & None \\
\hline $04-41$ & DHS Geotech boreholes (NCCT) & $\begin{array}{l}1 \text { inactive desert tortoise } \\
\text { burrow }\end{array}$ & $\begin{array}{c}3.68 \\
(9.09)\end{array}$ & $\begin{array}{c}0.15 \\
(0.37)\end{array}$ & Avoid flagged tortoise burrow \\
\hline $04-42$ & DAF Range Meter Signs & Yucca and Cacti & $\begin{array}{c}8.79 \\
(21.72)\end{array}$ & $\begin{array}{c}0.43 \\
(1.06)\end{array}$ & $\begin{array}{l}\text { Use existing roads and avoid yuccas } \\
\text { and cacti }\end{array}$ \\
\hline & & $\begin{array}{c}\text { Totals in ha } \\
\text { (ac) }\end{array}$ & $\begin{array}{c}256.18 \\
(633.03)\end{array}$ & $\begin{array}{c}102.28 \\
(252.74)\end{array}$ & \\
\hline
\end{tabular}

${ }^{\mathrm{a}}$ Building locations not shown on Figure 2-1; ${ }^{\mathrm{b}} \mathrm{CAU}=$ Corrective Action Unit; ${ }^{\mathrm{c}}$ Site was not on the NTS. 
The expected area to be disturbed in important habitat due to FY/CY 2004 projects is 46.29 (Table 2-3). Since FY 1999, a tally of all acreage proposed for disturbance within important habitats has been kept (Table 2-3). This tally may be used in the future to estimate the area and rate of establishment of invasive species into these habitats. Land-disturbing activities are known to cause the spread of invasive species such as Bromus rubens (red brome) into areas of the NTS where they have not previously occurred. Such non-native weeds can degrade important habitats by decreasing plant biodiversity and increasing the risk and spread of wildfires. The monitoring and control of invasive plants on federal lands is encouraged under Executive Order 13112, Invasive Species.

Table 2-3. Total area (in hectares) proposed for disturbance within important habitats in FY/CY 2004 and over the past six fiscal years.

\begin{tabular}{|c|c|c|c|c|c|}
\hline $\begin{array}{l}\text { Project } \\
\text { No. }\end{array}$ & Project Name & $\begin{array}{l}\text { Pristine } \\
\text { Habitat }\end{array}$ & $\begin{array}{l}\text { Unique } \\
\text { Habitat }\end{array}$ & $\begin{array}{c}\text { Sensitive } \\
\text { Habitat }\end{array}$ & Diverse Habitat \\
\hline $04-01$ & Jackass Flat Road Cleanup & 0 & 0 & 0 & 0.14 \\
\hline $04-03$ & Horn Silver Mine & 0.48 & 0 & 0 & 0 \\
\hline $04-06$ & U1h Leachfield & 0 & 0 & 0.22 & 0 \\
\hline $04-13$ & 5-07 Road Repair & 0 & 0 & 0.08 & 0 \\
\hline $04-15$ & Stockade Wash Road Gravel Pit & 0 & 0.30 & 0 & 0 \\
\hline $04-23$ & Area 6 Gravel Pit & 0 & 0 & 36.97 & 0 \\
\hline $04-25$ & P Tunnel Cleanup & 0 & 0 & 1.44 & 0 \\
\hline $04-29$ & $\begin{array}{l}\text { (NCCT) Area } 6 \text { Infrastructure Improvements - } \\
\text { Access and Power Line Roads }\end{array}$ & 0 & 0 & 4.59 & 0 \\
\hline $04-34$ & ER Wells & 0.93 & 0 & 0.84 & 0 \\
\hline $04-41$ & Bore holes (NCCT) & 0 & 0 & 0.15 & 0 \\
\hline \multirow[t]{3}{*}{$04-42$} & DAF Range Signs & $\underline{0}$ & $\underline{0.18}$ & $\underline{0}$ & $\underline{0}$ \\
\hline & Total ha FY/CY 2004 & 1.41 & 0.48 & 44.29 & 0.14 \\
\hline & Grand Total ha 1999 - 2004 & 9.08 & 8.51 & 129.75 & 78.59 \\
\hline
\end{tabular}




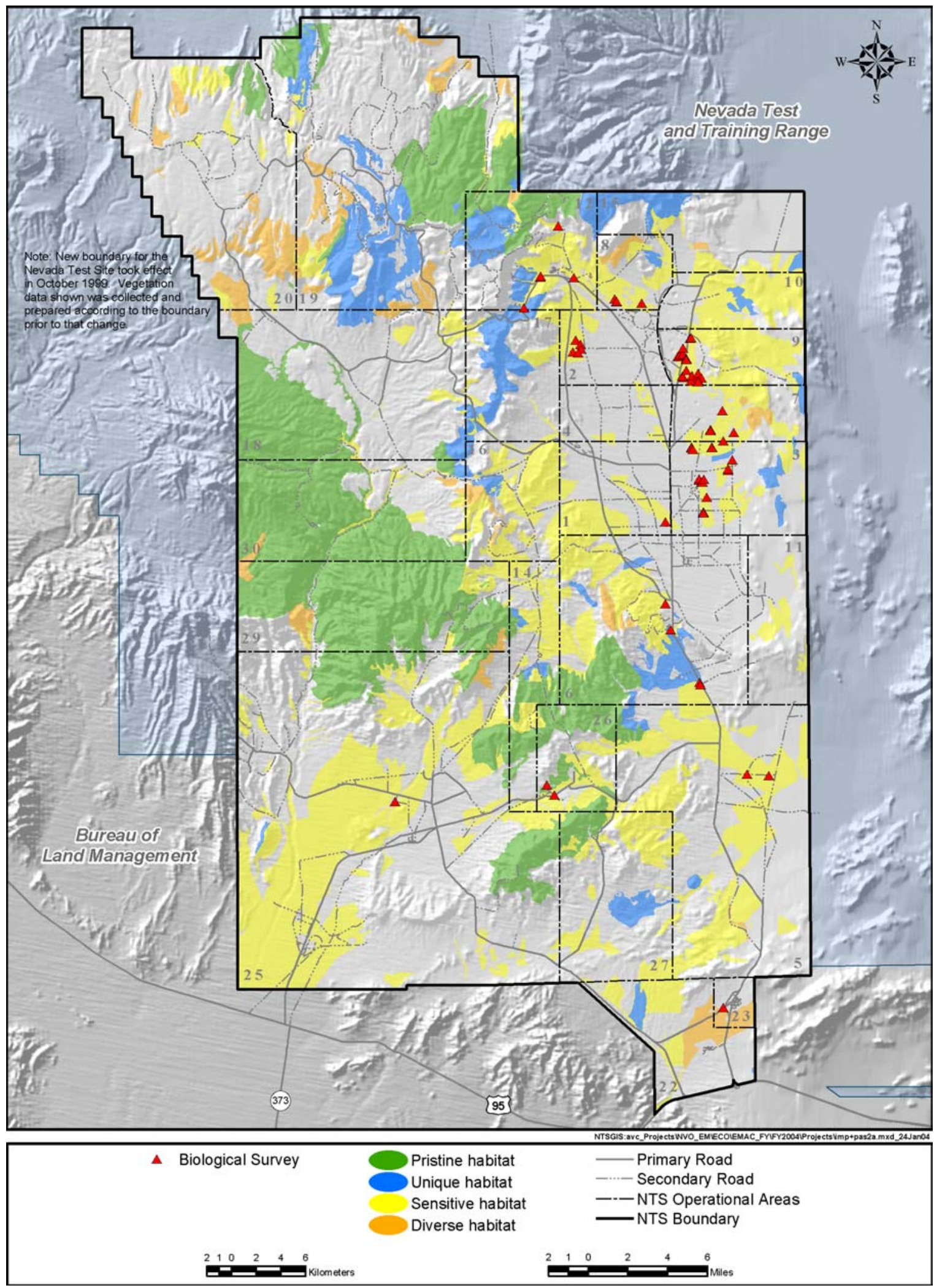

Figure 2-2. Biological surveys conducted in important habitats of the NTS during FY/CY 2004. 


\subsection{DESERT TORTOISE COMPLIANCE}

The desert tortoise occurs within the southern one-third of the NTS. This species is listed as threatened under the Endangered Species Act (ESA). In December 1995, NNSA/NSO completed consultation with the U.S. Fish and Wildlife Service (FWS) concerning the effects of NNSA/NSO activities, as described in the Final Environmental Impact Statement for the Nevada Test Site and Off-Site Locations in the State of Nevada (DOE/NV, 1996), on the desert tortoise. A final Biological Opinion (Opinion) (FWS, 1996) was received from the FWS in August 1996. The Opinion concluded that the proposed activities on the NTS were not likely to jeopardize the continued existence of the Mojave population of the species and that no critical habitat would be destroyed or adversely modified. All terms and conditions listed in the Opinion must be followed when activities are conducted within the range of the desert tortoise on the NTS.

The Desert Tortoise Compliance task of EMAC was developed to implement the terms and conditions of the Opinion, to document compliance actions taken by NNSA/NSO, and to assist NNSA/NSO in FWS consultations. The terms and conditions that were implemented by BN staff biologists in FY/CY 2004 included (a) conducting clearance surveys at project sites within one to seven days from the start of project construction, (b) ensuring that environmental monitors are on-site during heavy equipment operation, and (c) preparing an annual compliance report submitted to the FWS.

\subsection{Project Surveys and Compliance Documentation}

Biologists conducted biological and desert tortoise clearance surveys prior to ground-disturbing activities for 23 proposed projects (40 sites) within the range of desert tortoise on the NTS (Table 3-1, Figure 3-1). All but two of the project sites (Project No. 04-23 and 04-29), were in, or immediately adjacent to, existing facilities and disturbances. These 23 projects do not include the locations of buildings surveyed for bird nests and bat roosts (Project 03-18) which happened to be in the Mercury or CP complex within the geographic range of the desert tortoise. No viable tortoise habitat was found at these building sites and their locations are not shown in Figure 2-1.

Four inactive tortoise burrows were found during tortoise clearance surveys (Table 3-2). Two of the inactive tortoise burrows (Project No. 04-29) were examined with a fiberoptic scope, determined to be empty, and crushed within 24 hours from the start of construction. The other inactive tortoise burrows (Projects No. 04-21 \& 04-41) were flagged and avoided during cleanup activities. Project 04-23 disturbed 4.42 ha $(10.91 \mathrm{ac})$ of undisturbed land (Table 3-2). This project is located in southern Yucca Flat along the northern border of the geographic range of the desert tortoise. Project 04-29 disturbed 4.59 ha $(11.35 \mathrm{ac})$ of undisturbed habitat in northern Frenchman flats along the Mercury Highway. BN Ecological Services ensured that on-site construction monitoring was conducted by a designated environmental monitor at all sites where clearance surveys were performed.

Post-activity surveys to quantify the acreage of tortoise habitat actually disturbed were conducted for seven projects during this reporting period (Table 3-1). Post-activity surveys were not conducted if the projects were within the tortoise exclusion zone or if viable tortoise habitat was not found within the project area boundaries (due to previous disturbance) during the clearance survey and if the environmental monitor documented that the project stayed within its proposed boundaries. This year, a total of 9.23 ha $(22.81 \mathrm{ac})$ of disturbed tortoise habitat were documented (Table 3-1). 
Table 3-1. Summary of tortoise compliance activities conducted by BN biologists during FY/CY 2004

\begin{tabular}{|c|c|c|c|}
\hline $\begin{array}{l}\text { Project } \\
\text { Number }\end{array}$ & Project & Compliance Activities & $\begin{array}{c}\text { Tortoise Habitat } \\
\text { Disturbed } \\
\text { ha ( acres) } \\
\end{array}$ \\
\hline 04-01 & Barbed Wire Cleanup on Jackass Flats Road & $\begin{array}{l}100 \text { percent-coverage clearance survey, } \\
\text { post-activity survey }\end{array}$ & $0.002(0.005)$ \\
\hline 04-03 & Horn Silver Mine (CAU 527) & $\begin{array}{l}100 \text { percent-coverage clearance survey, } \\
\text { post-activity survey }\end{array}$ & $0.2(0.5)$ \\
\hline 04-04 & $\begin{array}{l}\text { Area 25, 26, and } 27 \text { Septic Systems } \\
\text { (Area } 27 \text { Leachfield, CAS 27-05-02) }\end{array}$ & $\begin{array}{l}100 \text { percent-coverage clearance survey, } \\
\text { no post-activity survey necessary* }\end{array}$ & $0(0)$ \\
\hline 04-09 & $\begin{array}{l}\text { Landfills (CAU 5) } \\
\text { (Sanitary Landfill, CAS 05-15-01) }\end{array}$ & 100 percent-coverage clearance survey & $0(0)$ \\
\hline $04-20$ & $\begin{array}{l}\text { Area } 25 \text { Contaminated Materials (CAU 529) } \\
\text { (Site E, Parcel C, Locations G \& A) }\end{array}$ & 100 percent-coverage clearance survey & $0.02(0.04)$ \\
\hline $04-21$ & Jackass Flats Road Cleanup & 100 percent-coverage clearance survey & $0(0)$ \\
\hline $04-23$ & Area 6 Gravel Pit & 100 percent-coverage survey & $4.42(10.91)$ \\
\hline $04-29$ & $\begin{array}{l}\text { NCCT Area } 6 \text { Infrastructure Improvements } \\
\text { (Access Road and Powerline Road) }\end{array}$ & 100 percent-coverage clearance survey & $4.59(11.35)$ \\
\hline $04-30$ & $\begin{array}{l}\text { Decon Pads and Septic Systems (CAU 224) } \\
\text { (5 sites) }\end{array}$ & $\begin{array}{l}100 \text { percent coverage clearance survey, } \\
\text { no post-activity survey necessary* }\end{array}$ & $0(0)$ \\
\hline 04-31 & CAU 300 (4 sites) & $\begin{array}{l}100 \text { percent- coverage clearance survey, } \\
\text { no post-activity survey necessary* }\end{array}$ & $0(0)$ \\
\hline $04-32$ & Jackass Flats Road Grading & $\begin{array}{l}100 \text { percent- coverage clearance survey, } \\
\text { no post-activity survey necessary* }\end{array}$ & $0(0)$ \\
\hline $04-35$ & NRDS Road Grading & $\begin{array}{l}100 \text { percent- coverage clearance survey, } \\
\text { no post-activity survey necessary* }\end{array}$ & $0(0)$ \\
\hline 04-39 & CAU 165 Engine Test Stand & $\begin{array}{l}100 \text { percent - coverage clearance survey } \\
\text { Post-activity survey necessary }\end{array}$ & TBD \\
\hline $04-40$ & CAU 5 Landfills (3 sites) & $\begin{array}{l}100 \text { percent - coverage clearance survey } \\
\text { no post-activity survey necessary* }\end{array}$ & $0(0)$ \\
\hline $04-41$ & DHS Geotech Boreholes (NCCT) & $\begin{array}{l}100 \text { percent coverage clearance survey } \\
\text { Post-activity survey necessary }\end{array}$ & TBD \\
\hline \multirow[t]{2}{*}{$04-42$} & DAF Range Markers Signs & $\begin{array}{l}100 \text { percent coverage clearance survey } \\
\text { Post-activity survey necessary }\end{array}$ & TBD \\
\hline & & Total & $9.232 \quad(22.805)$ \\
\hline
\end{tabular}

* Post-activity survey was unnecessary because project was located within previously-disturbed tortoise habitat $* * \mathrm{TBD}=$ To be determined 


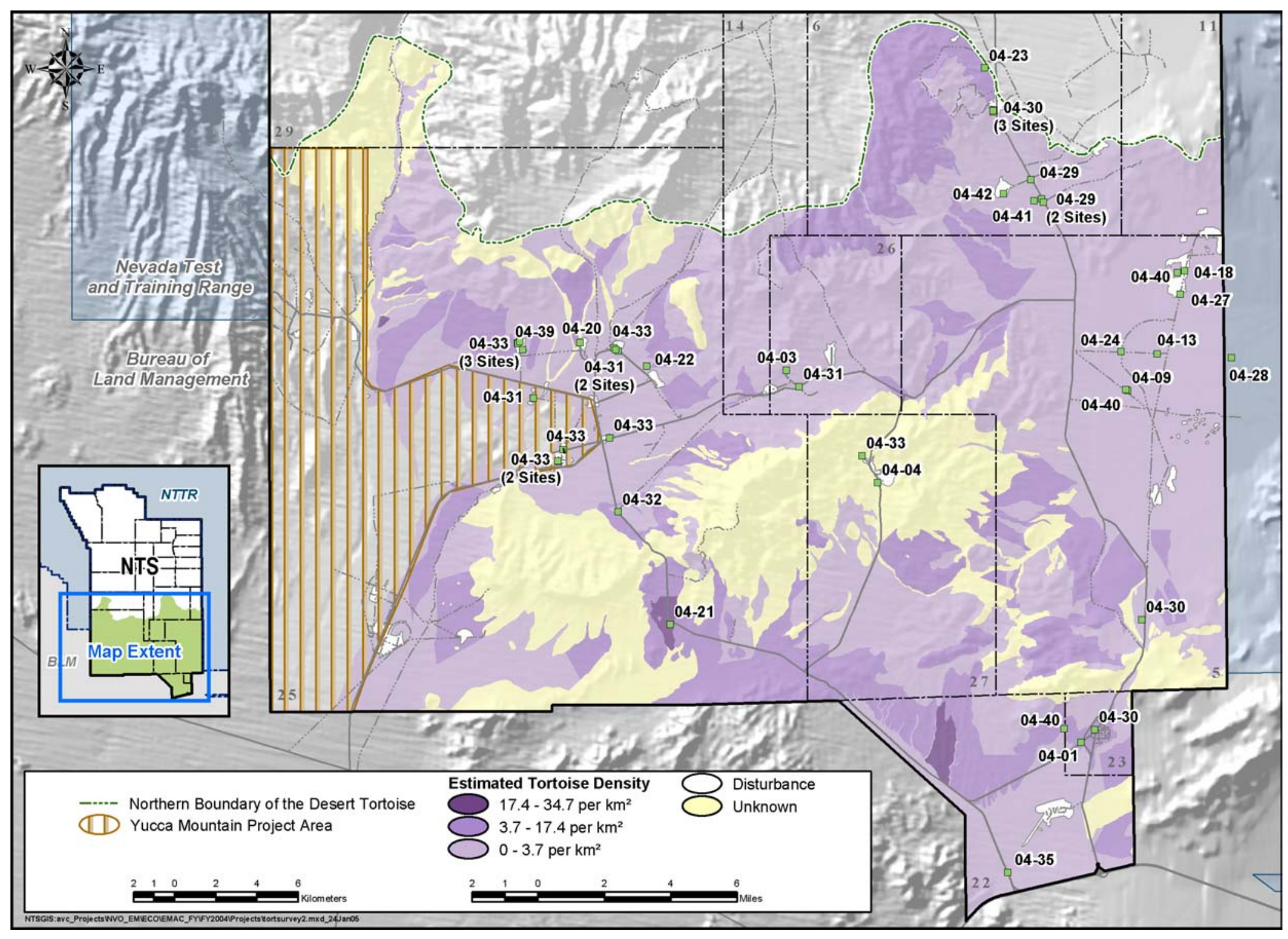

Figure 3-1. Biological surveys conducted in desert tortoise habitat on the NTS in FY/CY 2004. 
In January, BN submitted to ESHD the annual report that summarized tortoise compliance activities conducted on the NTS from January 1 through December 31, 2004. This report, required under the Opinion, contains (a) the location and size of land disturbances that occurred within the range of the desert tortoise during the reporting period; (b) the number of desert tortoises injured, killed, or removed from project sites; (c) a map showing the location of all tortoises sighted on or near roads on the NTS; and (d) a summary of construction mitigation and monitoring efforts.

Compliance with the Opinion will ensure that the two goals of the NNSA/NSO's Resource Management Plan (DOE/NV, 1998) are being met; namely, that the desert tortoise is protected on the NTS and that the cumulative impacts on this species are minimized. In the Opinion, the FWS has determined that the "incidental take" of tortoises on the NTS and the cumulative acreage of tortoise habitat disturbed on the NTS are parameters to be measured and monitored annually. During this fiscal year, the threshold levels established by the FWS for these parameters were not exceeded (Table 3-2). No desert tortoises were accidentally injured or killed, nor were any captured or displaced from project sites. Three desert tortoises were killed along roadways within the NTS.

Table 3-2. Parameters and threshold values for desert tortoise monitoring on the NTS

\begin{tabular}{|c|c|c|c|}
\hline Monitored Parameter & $\begin{array}{l}\text { Threshold } \\
\text { Value }\end{array}$ & Adaptive Management Action & $\begin{array}{l}\text { FY/CY } 2004 \\
\text { Value of } \\
\text { Monitored } \\
\text { Parameter }\end{array}$ \\
\hline $\begin{array}{l}\text { Number of tortoises accidentally injured or killed as a } \\
\text { result of NTS activities per year }\end{array}$ & 3 & $\begin{array}{l}\text { Reinitiate consultation with } \\
\text { FWS }\end{array}$ & 0 \\
\hline $\begin{array}{l}\text { Number of tortoises captured and displaced from NTS } \\
\text { project sites per year }\end{array}$ & 10 & $\begin{array}{l}\text { Reinitiate consultation with } \\
\text { FWS }\end{array}$ & 0 \\
\hline $\begin{array}{l}\text { Number of tortoises taken in form of injury or mortality } \\
\text { on paved roads on the NTS by vehicles other than those } \\
\text { in use during a project }\end{array}$ & Unlimited & $\begin{array}{l}\text { Supplemental employee } \\
\text { education and bulletins }\end{array}$ & 3 \\
\hline $\begin{array}{l}\text { Number of total hectares (ac) of desert tortoise habitat } \\
\text { disturbed during NTS project construction since } 1992\end{array}$ & $1,220(3,015)$ & $\begin{array}{l}\text { Reinitiate consultation with } \\
\text { FWS }\end{array}$ & $97.13 \quad(240.01)$ \\
\hline
\end{tabular}

\subsection{Habitat Revegetation Plan For Loss of Tortoise Habitat}

Mitigation for the loss of tortoise habitat is required under the terms and conditions of the Opinion. The Opinion requires NNSA/NSO to perform either of two mitigation options: 1) pre-pay Clark County \$262 per each hectare ( $\$ 648$ for each acre) of habitat disturbed, or 2) revegetate disturbed habitat following specified criteria. Since 1992, NNSA/NSO has been using the balance of $\$ 81,000$ that NNSA/NSO deposited into a Clark County fund to pre-pay for the future disturbance of 250 acres of tortoise habitat on the NTS. As of December 31, 2004, this fund has used \$77,763 to compensate for 240.01 acres.

\footnotetext{
${ }^{1}$ To "take" a threatened or endangered species, as defined by the ESA, is to harass, harm, pursue, hunt, shoot, wound, kill, trap, capture or collect, or attempt to engage in any such conduct.
} 
Since only $\$ 3,237$ (less than 10 acres) is available for future compensation, it is necessary to develop future strategies for funding and/or implementing habitat mitigation so that work in tortoise habitat may continue without interruption in the future.

BN biologists prepared a plan to revegetate tortoise habitat whenever it is reasonable and prudent to fund. The plan proposes that the pre-paid Clark County fund continue to be used for selected sites, for example, sites that will not be released from project use in the near future and therefore cannot be revegetated, and those abandoned sites in very poor habitat where revegetation is expected to be costly or unsuccessful. NNSA/NSO submitted this habitat revegetation plan to the FWS. This plan was approved by FWS on October 5, 2004.

\subsection{Coordination With Other Wildlife Agencies/Biologists}

In mid-October 2003, a BN biologist accompanied a team of volunteer biologists, led by Phil Medica of the Southern Nevada Field Office of the FWS to Rock Valley in Area 25. Three 21-acre circular enclosures in Rock Valley were constructed during 1962-1963 to study the effects of chronic, low-level ionizing radiation on the desert flora and fauna. Over the past decades, at least 24 tortoises have been found, individually marked, and periodically measured. In 2002 there were approximately 18 adult tortoises remaining in the enclosures.

During the October 2003 Rock Valley survey, biologists located three live tortoises and found the remains of six tortoises of known age. Only one of the three live tortoises was found aboveground and was weighed and measured. The remains of the six tortoises were salvaged. Based on inter-canine distance measurements from tortoise shell remains and the manner in which five of the tortoises were consumed, a large predator such as a mountain lion (Felis concolor) is suspected of killing the tortoises.

During November, BN biologists set up remote camera systems (two 35-millimeter [mm] cameras and one video camera) at five different locations outside of the enclosed study plots in Rock Valley. Styrofoam desert tortoise forms baited with fish fillets were placed in view of the cameras to attract predators. No mountain lions were detected by the camera systems. The only predator detected was kit fox (Vulpes macrotis). 
THIS PAGE INTENTIONALLY LEFT BLANK 


\subsection{ECOSYSTEM MAPPING/DATA MANAGEMENT}

In FY 1996, Ecological Services began to map wildlife habitat and plant communities of the NTS. Data about selected biotic and abiotic habitat features were collected within field mapping units called Ecological Landform Units (ELUs). ELUs are landforms (Peterson, 1981) with similar vegetation, soil types, slope, and hydrology. Boundaries of the ELUs were defined using aerial photographs, satellite imagery, and field confirmation. ELUs are considered to be the most feasible mapping unit by which sensitive plant and animal habitats can be described. In December 2000, a topical report describing the classification of habitat types was published and distributed (Ostler et al., 2000). Ten vegetation alliances and 20 associations were recognized as occurring on the NTS.

In FY/CY 2004 efforts continued to update and improve this habitat data. Efforts were focused on the following tasks in support of ecosystem mapping and data management of all NTS geospatial ecological data:

- Vegetation Mapping in NTS Area 20

- Sampling of Selected ELUs for Canopy Cover Data

- Vegetation Survey for Determining Wildland Fire Hazards

- Coordination With Ecosystem Management Agencies and Scientists

\subsection{Vegetation Mapping in NTS Area 20}

In FY 1999 the NTS site boundaries were changed and additional land was added to the NTS, particularly in Administrative Area 20, in the northwest corner surrounding the Schooner event site. Vegetation on this land had not been previously sampled nor mapped. In FY/CY 2004 approximately 10 additional ELUs were sampled and vegetation boundaries were determined for this new area as shown in Figure 4-1. A draft GIS map of this quadrangle was completed in FY/CY 2004 and is expected to be finalized in CY 2005 as part of the wildlife habitat mapping begun in FY 2003.

\subsection{Sampling of Selected ELUs for Canopy Cover Data}

ELUs that were sampled in 1996 did not contain information about shrub canopy cover, and because 1996 was a drought year few annual plant species grew, resulting in a lack of information about canopy cover and annual species. Data collected after 1996 documented shrub canopy cover and had better representation of annual plant species. Photographs taken during 1996 were also substandard. They were made from transparency slides and the color quality of the slide film shifted dramatically through the season and during the five years since they were taken. For these reasons, a need was recognized to secure additional photos and data about vegetation on ELUs sampled during 1996 (about 500 sites).

Beginning in 1999, selected ELUs have been revisited as the opportunity presents itself, often during the conduct of other EMAC field activities, to obtain better photographs and vegetation data. During 2004, 68 ELUs were revisited to collect additional photographs and information. The new photos and data were added and linked to the existing Ecological Geographic Information System (EGIS) database. Canopy cover data were also used to update the vegetation fuels wildland fire hazard assessment for the NTS conducted in FY/CY 2004. 


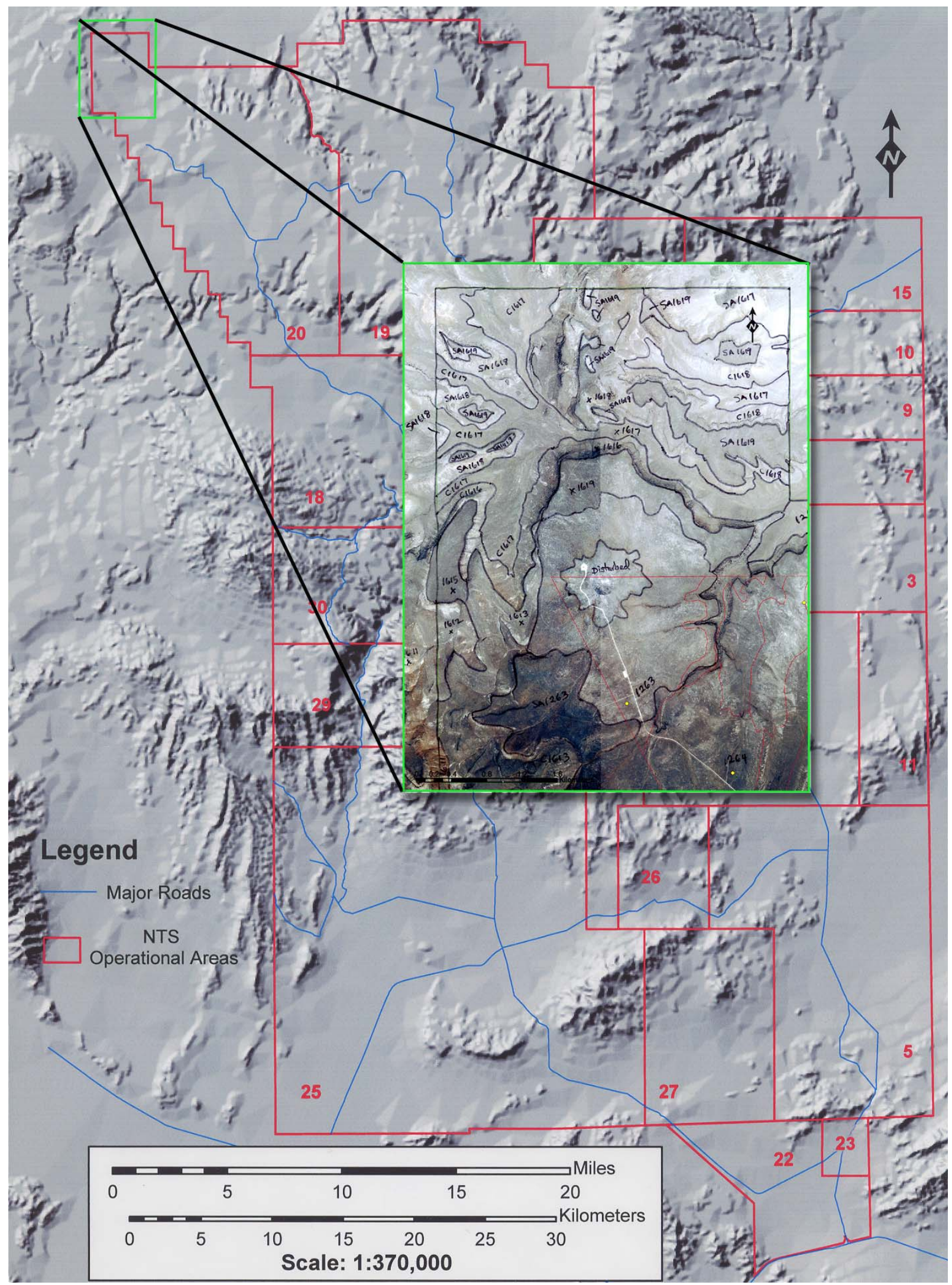

Figure 4-1. Portions of NTS Area 20 where vegetation was mapped in FY/CY 2004. 


\subsection{Vegetation Survey for Determining Wildland Fire Hazards}

Wildland fires have burned thousands of acres on the NTS and have required considerable financial resources for fire suppression and mitigation. For example, a large fire in 2002, the Egg Point Fire, cost well over \$1 million to replace burned power poles and other resources and cost more than $\$ 200,000$ to stabilize and revegetate the area. These fires do not occur randomly across the NTS but occur more often in particular vegetation types that have sufficient fuels (woody and fine-textured fuels) that are conducive to ignition and spread of wildland fires. Once a site burns it is much more likely to burn again because of the invasive annual plants that quickly colonize these areas unless the areas are revegetated with perennial native species. Mapping of historic burns, fire-sensitive vegetation types, and annual fuel loads using GIS can provide valuable tools to control wildfires on the NTS such as strategically locating fire fighting equipment or restricting activities in sensitive areas during the fire season when hazards are particularly high.

On January 15, 2003 DOE Order 450.1 "Environmental Protection Program" was approved. This new order replaced DOE Order 5400.1 and added specific requirements for the protection of site resources from wildland and operational fires. In response to the new order efforts were made in FY/CY 2004 to characterize vegetation resources and climatic components of the environment that might contribute to wildland fires on the NTS. New information about fuels was collected by road surveys in the spring of 2004 to approximate the hazards resulting from new growth of vegetation on the NTS. This growth was largely influenced by precipitation received during the months of January through April of 2004. The field survey assessed 211 sites along major NTS corridors for the abundance of native perennial and annual species and invasive weeds. The abundance of fine-textured (grasses and herbs) and coarsetextured (woody) biomass was visually estimated on numerical scales ranging from one to five.

The results of the survey are reported by Hansen and Ostler (2004). The report was designed to help update the Wildland Fire Management Plan and to communicate potential wildland fire hazards that change annually in response to fluctuating climatic conditions. In the report, distribution of biomass is shown in Geographic Information System maps by NTS operational area. For example, Figure 4-2 shows the locations of survey sites sampling during FY/CY 2004 and the combined fuel hazards indices when fine fuels and woody fuels are combined with equal weighting. The report also includes GIS maps showing physical (elevation, slope, and aspect) and climatic (meteorological recording stations, precipitation, and lightning flashes) features of the landscape. Precipitation on the NTS from January through April 2004 was only about 0.4 percent above average. Future weather for the NTS fire season (June through September) was projected to be about normal precipitation with increased temperatures, a 40 to 50 percent chance of being above-average (temperature). Long-term forecasts (10-30 years) suggested hotter and drier conditions in southern Nevada.

There has been an average of 6.5 wildland fires per year on the NTS over the past decade with an average of about 396 ha (980 ac) per fire. A map showing the location (Figure 4-3) and description of historic fires was presented (Hansen and Ostler, 2004). The three most commonly observed invasive annual plants to colonize burned areas are Arabian schizmus (Schizmus arabicus at low elevations), red brome (Bromus rubens at lower to moderate elevations), and cheat grass (Bromus tectorum at moderate to higher elevations). Colonization by invasive species increases the likelihood of future wildland fires because they provide abundant fine fuels that are more closely spaced than native vegetation. Blackbrush (Coleogyne rammosissima) vegetation types appear to be the most vulnerable plant communities to fire followed by pinyon-juniper/sagebrush vegetation types. Wildland fires are costly to control and to mitigate once they occur. Revegetation of burned areas is very slow without reseeding or transplanting with native species and other rehabilitation efforts. Untreated areas become much more vulnerable to future fires once invasive species, rather than native species, colonize a burned area. 


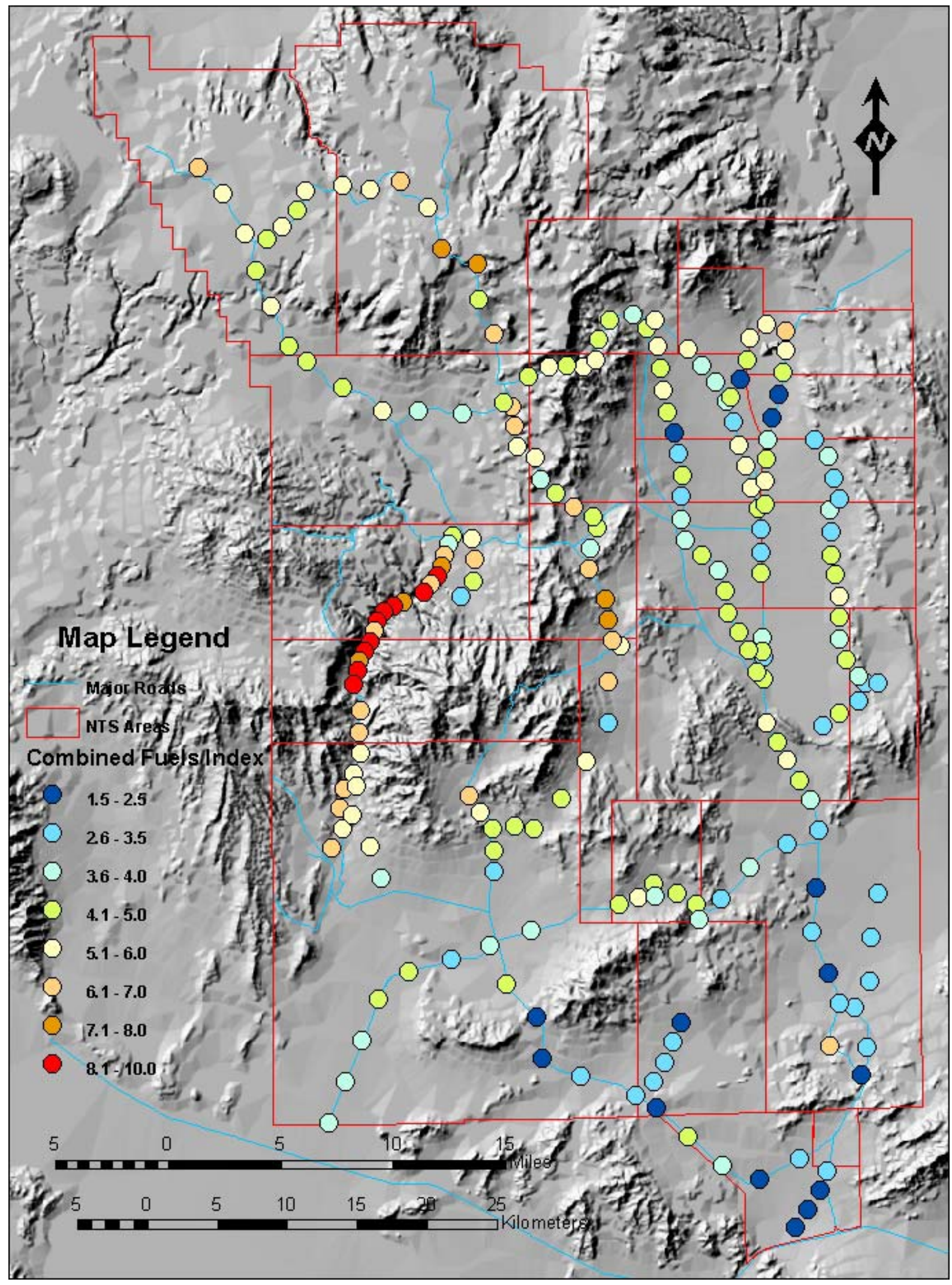

Figure 4-2. Wildland fire hazard assessment sites on the NTS by hazard class in FY/CY 2004. 


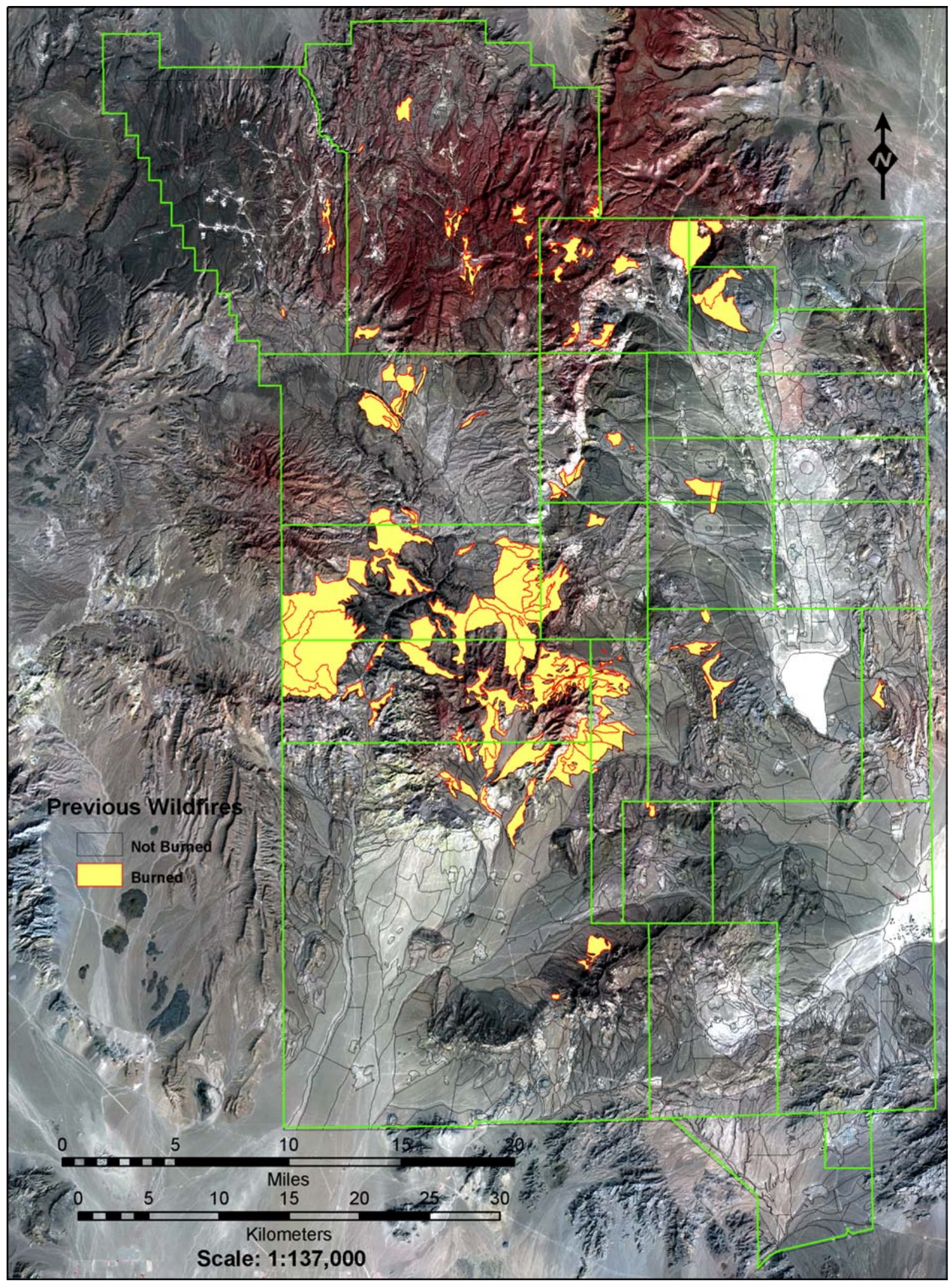

Figure 4-3. Location of large historic wildland fires on the NTS. 
Recommendations were made by Hansen and Ostler (2004) to increase education of NTS workers and users about the risks and hazards of wildland fires, especially during years of above-average spring precipitation when annual, fine-textured biomass is abundant. Adequate equipment and proper training is needed to ensure that workers, firefighters, and managers are prepared to prevent and control wildland fires in a cost-effective and environmentally sound manner, one that does not jeopardize the mission and function of the NTS. The annual assessment of wildland fire hazards on the NTS is scheduled to be implemented each spring in the near future with results being reported directly to the DOE and BN Fire Marshal.

\subsection{Coordination With Ecosystem Management Agencies and Scientists}

BN biologists interfaced with other ecosystem management agencies and scientists in 2004 and the following activities:

- Accompanied scientists from Neptune and Company, Inc., of Los Alamos, New Mexico to their NTS sampling locations and provided procedural oversight of their field research. Their research involves characterizing the potential biointrusion of ants and termites into buried waste.

- Presented a technical paper at the combined conferences of the Soil Conservation Society, Agronomy Society, and Crop Science Society in Denver, Colorado in November 2003 describing a new technique developed by BN scientists for evaluating vegetation impacts from off-road vehicles in the Mojave Desert (Hansen and Ostler, 2004).

- Provided a review for the USGS of their publication on the historic habitat plots established by Janice Beatley on the NTS in the 1970s. The document is entitled "Perennial Vegetation Data from Permanent Plots on the Nevada Test Site, Nye County, Nevada," Open-File Report 03-336.

- Interfaced with biologists at White Sands Missile Range in New Mexico coordinating information about wildland fires on DoD and DOE sites. Also attended the Tenth Biennial 2004 USDA Forest Service Remote Sensing Applications Conference in Salt Lake City, Utah which focused on remote sensing technologies for resource management and wildland fires.

- Attended the 2004 Department of Defense Conservation Conference in Savannah, Georgia and presented a poster on previous BN work on Mojave Desert reclamation and vegetation assessment. 


\subsection{SENSITIVE SPECIES AND HABITAT MONITORING}

There are 19 plants and 27 animals which occur on the NTS that are considered sensitive because they occur on the Nevada Natural Heritage Program sensitive species list or have a high or moderate risk rating in the Nevada Bat Conservation Plan Bat Species Risk Assessment. These include the desert tortoise which is listed as a threatened species under the ESA. EMAC tasks related to the desert tortoise are addressed in Section 3.0 of this report. The goal of monitoring sensitive species is to ensure the continued presence of all sensitive plants and animals on the NTS by protecting them from significant impacts due to NNSA/NSO actions. A secondary goal is to gather sufficient information on these species' distribution and abundance on the NTS to determine their status and if further protection or management under state or federal law is necessary. Natural and human-made water sources on the NTS are rare and unique habitats which are also routinely monitored to assess their status and use by wildlife.

\subsection{Sensitive Plant Species}

In 1998, DOE/NV prepared a Resource Management Plan (RMP) with the objective to protect and conserve sensitive plant species found on the NTS and to minimize cumulative impacts to those species as a result of DOE activities (DOE/NV, 1998). Pursuant to that document, BN published and distributed an Adaptive Management Plan for Sensitive Plant Species on the Nevada Test Site (BN, 2001). This document presents the procedures designed to ensure that the RMP goals are met by identifying parameters to be measured during long-term monitoring and outlining management actions that may be taken if significant threats to sensitive species are detected.

\subsubsection{Revised List of Sensitive Plant Species for the NTS}

The Adaptive Management Plan recommends the identification of those plant species found on the NTS that may require protection because of such factors as rarity, susceptibility to disturbance, or importance. Other agencies are also consulted in determining which species should be protected. Under the NNHP, the Nevada Department of Conservation and Natural Resources maintains a detailed list of rare vascular and non-vascular plants, which includes plants protected by federal agencies, the Division of Forestry of the State of Nevada, and the Nevada Native Plant society. Any species included on the NNHP list of sensitive plant taxa and are known or suspected to occur on the NTS are included in the list of sensitive plant species for the NTS (see Table 2-1, shown previously).

The list of sensitive plant species for the NTS was reviewed this year. One vascular plant species was added to the list and four non-vascular plant species were deleted. None of the sensitive plant species known to occur on the NTS are listed by the FWS as endangered or threatened or by the State of Nevada as critically endangered. Currently there are 18 vascular plant species and one non-vascular plant species that are listed as sensitive plant taxa by the NNHP (see Table 2-1, shown previously) and are known to occur or could potentially occur on the NTS.

\subsubsection{Long-term Monitoring}

Long-term monitoring of sensitive plant species is part of the Adaptive Management Plan. The goal of long-term monitoring is to acquire an accurate delineation of populations of sensitive plant species on the NTS and to periodically assess their status for conservation and management purposes. Sensitive plant species are subjected to one of three levels of monitoring; (1) those species that are actively monitored, (2) those not monitored, or (3) those species to be evaluated. Species actively monitored are those known to occur on the NTS, are on the NNHP list of sensitive plant species, and have limited distribution either on the NTS or its entire range. Species not monitored are termed "inactive" (see Table 2-1, shown 
previously) and are thus not included in the long-term monitoring plan for NTS plant species. They include species that are known to occur on the NTS and for which there is sufficient information to suggest that their distribution is widespread enough on the NTS, in Nevada, or over their entire population range that protective actions are not needed. Their presence at proposed project sites is still documented during biological surveys. Species to be "evaluated" (see Table 2-1, shown previously) are those for which there is insufficient information to determine if they occur on the NTS or if they do occur whether their distribution or abundance warrants protection and monitoring.

The list of sensitive plant species on the NTS (see Table 2-1, shown previously) includes eight species to be actively monitored, two to be evaluated, and ten that will not be monitored. Two of the eight species that will be monitored are annual forbs, five are perennial forbs, and one is a perennial shrub. The single species to be evaluated is a bryophyte (moss). The list of sensitive plant species on the NTS reflects two changes from 2003. Sclerocactus polyancistrus was added to the list based on herbarium records. It will not be among the species to be actively monitored but will be considered during plant surveys prior to ground disturbing activities on the NTS. Based on plant descriptions and distributions four moss species will no longer be included on the sensitive plant list. The species were known to occur in Clark County but the potential for them to be found on the NTS is unknown.

Field monitoring to assess population status is to be conducted for each "active" species at least once every five years. A minimum of two species are selected each year and a representative number of populations are monitored. For most of the sensitive species population locations and habitat descriptions have been recorded during previous field studies (Blomquist, et al., 1992, Blomquist et al., 1995). Other data will be collected during field monitoring to ascertain the current status of the species and may include density of plants, signs of herbivory, disease, or evidence of direct or indirect disturbance to its habitat.

Three species were selected to be monitored this year: Eriogonum concinnum (Darin's buckwheat), an annual forb; Ivesia arizonica var. saxosa (Whitefeather ivesia) and Lathyrus hitchcockianus (Hitchcock's peavine), both perennial forbs.

\subsubsection{Eriogonum concinnum}

E. concinnum is an annual herb with erect stems reaching 76 centimeter $(\mathrm{cm})(30$ inches [in]) high. It has relatively large bright green basal leaves and small greenish white flowers (Figure 5-1). The plant typically flowers during the summer months of June and July making it the best time for field surveys. Surveys were conducted for this species in 2002 and 2003 but only plant skeletons were found, suggesting the presence of a species of Eriogonum, but confirmation of the presence of E. concinnum was not possible.

The goals of this year's efforts for this species were to first confirm the presence at the known population sites, identify any potential threats to the species, estimate the number of plants present at each of the sites, and as time permitted during the survey window, conduct surveys of potential habitat. Meandering survey transects were walked through typical habitat. No permanent transects were established, as is done for perennial species that are monitored, because of the more disjoint distribution of annual plants. Habitat locations were recorded and the number of plants at each location was estimated. No plant density data has been reported for any of the known locations for this species in previous years. Habitat characteristics were recorded including slope, aspect, associated species and potential threats to the species if any were evident. 


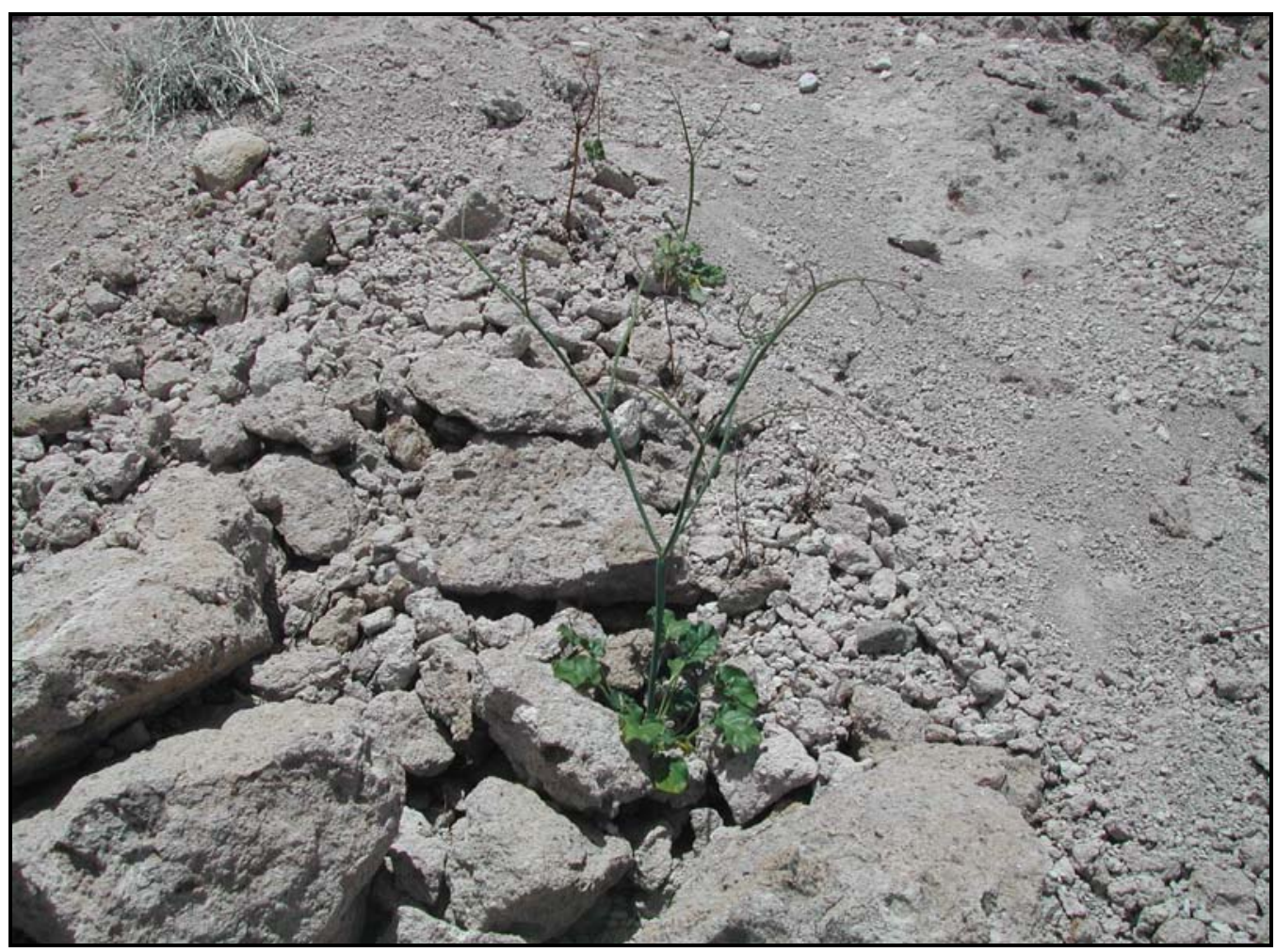

Figure 5-1. Eriogonum concinnum growing in tuffaceous soils near Silent Canyon in Area 19 of the NTS.

(Photo by D. Anderson, September 15, 2004).

Eriogonum concinnum has been reported from several locations on the NTS (Figure 5-2). It is found in the base of rocky slopes of light colored volcanic soils west of Buckboard Mesa road in Area 18, south of Pinyon Butte, west of the Sugar Loaves along Pahute Mesa Road, and northeast of Silent Canyon in Area 19. There is a reported collection of E. concinnum near Reitmann Seep in Area 7, but no living plants have been located at this site during the last three years. E. concinnum is also found on road cuts in light volcanic soils along Buckboard Mesa and Pahute Mesa roads in Areas 19 and 20.

Eight known locations of E. concinnum were surveyed in 2004. At previous collection sites near Reitmann Seep and at the Holmes Road - Stockade Wash Road junction, no plants were found this year as has been the experience the last three years. One reported site in Area 19 was inaccessible due to a washed out road. At the six other locations numerous plants were found. The largest population was at the site along Buckboard Mesa Road. This site was surveyed in 2003 but no plants were found. This year over 1,500 plants were counted (Table 5-1). The same was true for the site north of Pinyon Butte (Figure 5-3). In 2003 the entire area was surveyed but no plants were found. This year nearly 1,000 plants were encountered. Hundreds of plants were found at the other sites. At the one new site on the western slope of Rattlesnake Ridge, plants were found at the base of the cliffs for nearly a mile. No density counts were made at the other new site south of the Silent Canyon near the junction of Pahute Mesa Road and the 19-03 Road. The data collected this year will serve as a baseline for future monitoring because this is the first attempt at quantifying the size of the different populations on the NTS. 


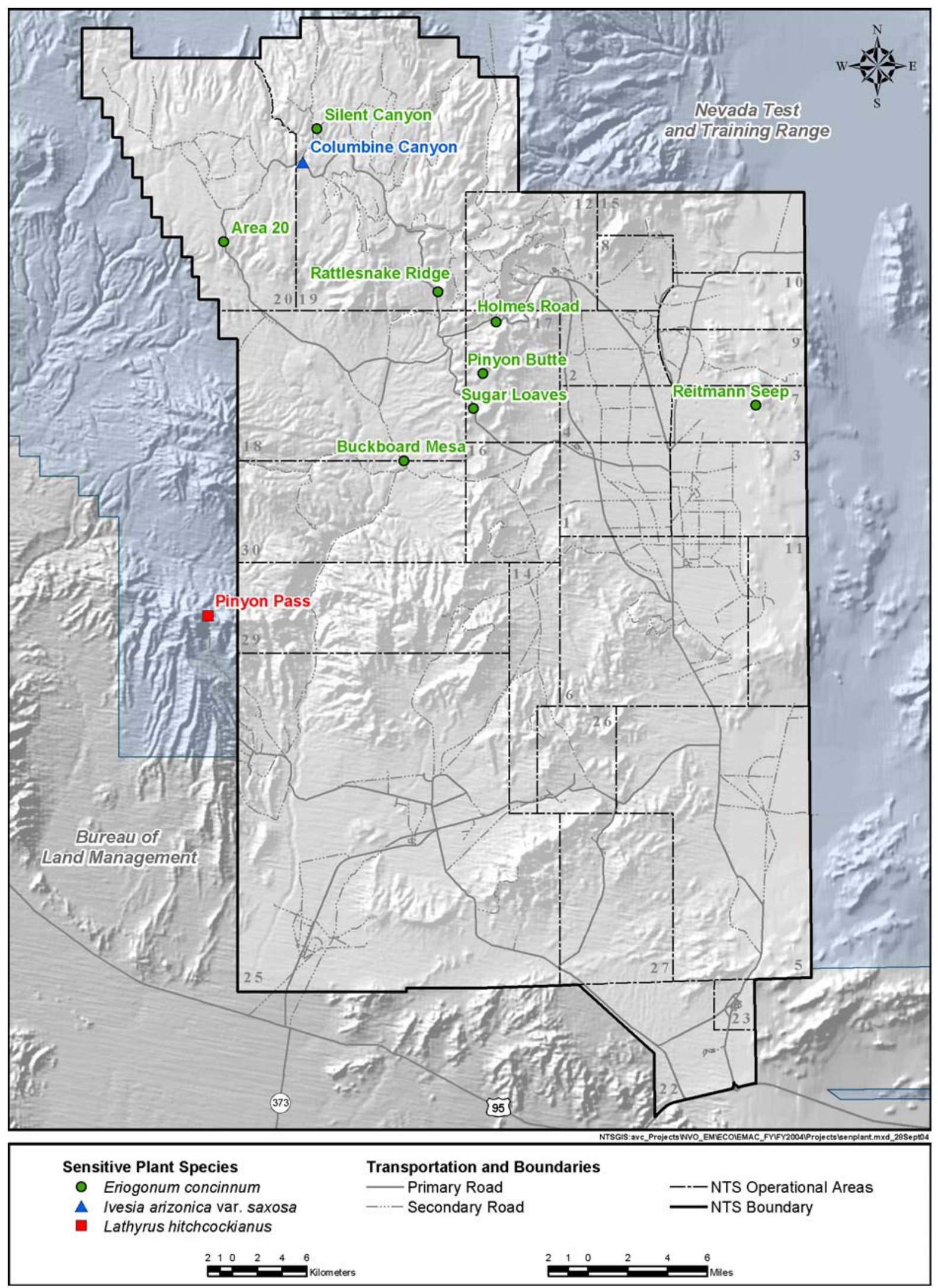

Figure 5-2. Sensitive plant populations monitored on or near the NTS during FY/CY 2004. 
Table 5-1 Characteristics of Eriogonum concinnum habitat on the NTS.

\begin{tabular}{|c|c|c|c|c|c|c|}
\hline \hline $\begin{array}{c}\text { Habitat } \\
\text { Feature }\end{array}$ & $\begin{array}{c}\text { Buckboard } \\
\text { Mesa }\end{array}$ & Area 20 & Silent Canyon & $\begin{array}{c}\text { Rattlesnake } \\
\text { Ridge }\end{array}$ & $\begin{array}{c}\text { Sugar } \\
\text { Pinyon Butte }\end{array}$ \\
\hline Elevation & $\begin{array}{c}1,478 \mathrm{~m} \\
(4,850 \mathrm{ft})\end{array}$ & $\begin{array}{c}1,829-1,859 \mathrm{~m} \\
(6,000-6,100 \mathrm{ft})\end{array}$ & $\begin{array}{c}1,981-1,996 \mathrm{~m} \\
(6,500-6,550 \mathrm{ft})\end{array}$ & $\begin{array}{c}1,859-1,865 \mathrm{~m} \\
(6,100-6,120 \mathrm{ft})\end{array}$ & $\begin{array}{c}1,823-1,859 \mathrm{~m} \\
(5,980-6,100 \mathrm{ft})\end{array}$ & $\begin{array}{c}1,753 \mathrm{~m} \\
(5,750 \mathrm{ft})\end{array}$ \\
\hline $\begin{array}{c}\text { Vegetation } \\
\text { Association }\end{array}$ & $\begin{array}{c}\text { Saltbush } \\
\text { Soils }\end{array}$ & Sagebrush & $\begin{array}{c}\text { Pinyon Pine/ } \\
\text { Sagebrush }\end{array}$ & Sagebrush & Sagebrush & Sagebrush \\
\hline $\begin{array}{c}\text { Slope } \\
\text { (percent) }\end{array}$ & $1-10$ & Rocky, light & Volcanic tuff & Volcanic tuff & White volcanic \\
talus & $\begin{array}{c}\text { Rocky, } \\
\text { light } \\
\text { volcanic } \\
\text { tuff }\end{array}$ \\
\hline $\begin{array}{c}\text { Plant } \\
\text { Abundance }\end{array}$ & 1,640 & $35+$ & $10-35$ & $1-10$ & $10-35$ \\
\hline \hline
\end{tabular}

${ }^{1}$ Classification as per Ostler et al., 2000.

${ }^{2}$ Number of individuals estimated during site visits

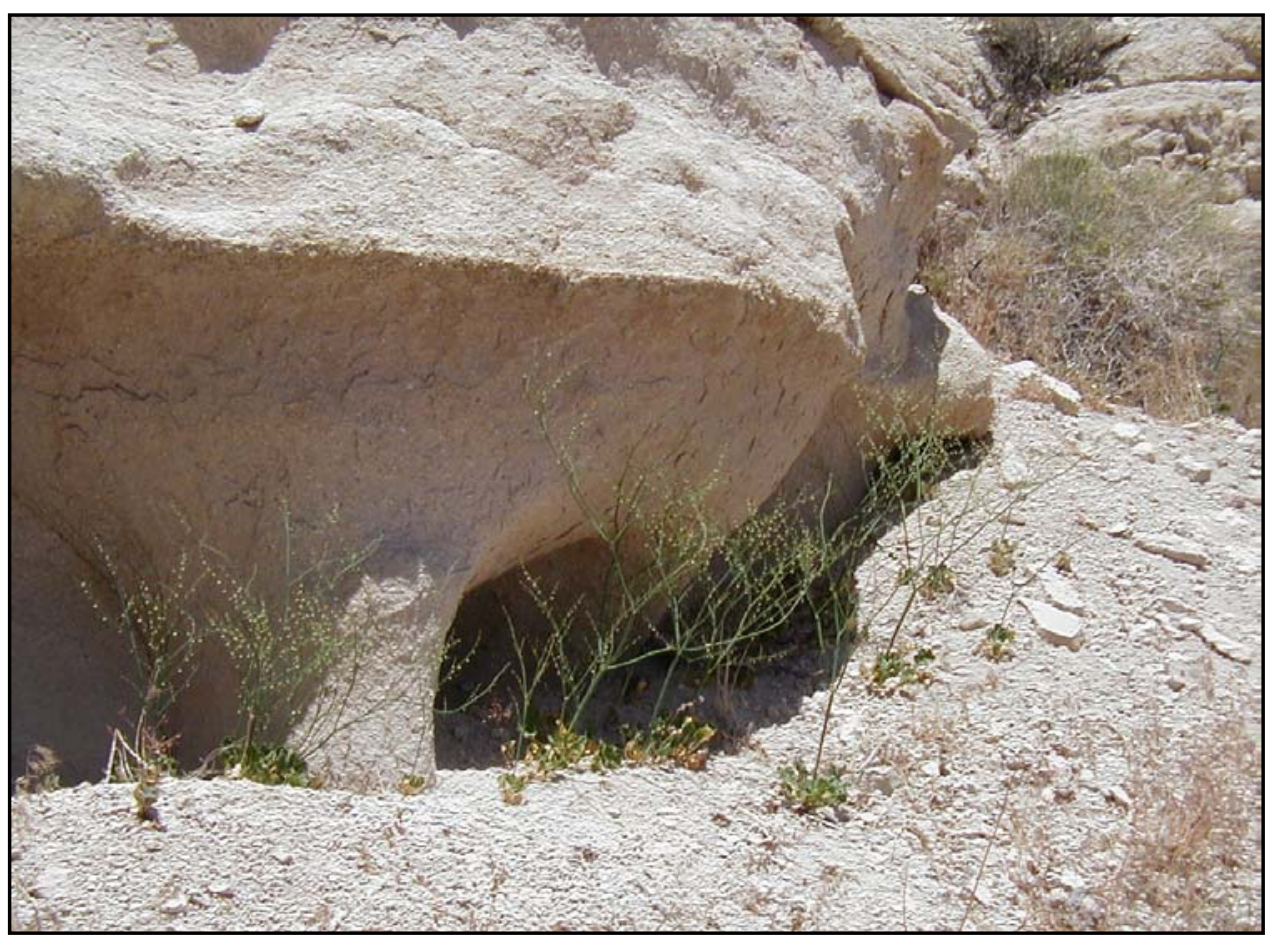

Figure 5.3. Typical habitat of Eriogonum concinnum south of Pinyon Butte. (Photo by D. Anderson, September 15, 2004). 
No apparent threats to the species were noted at any of the sites. The site in Area 20 is located on a steep road cut, but even with the sloughing soils on this road cut, E. concinnum seems to survive. Like several other sensitive plant species, there has not been an effort to document the full distribution of

E. concinnum on the NTS. Two new sites were added to the overall distribution of the species this year and potential habitat for this species is found over much of the NTS. Although commonly found on the NTS this species is rarely found elsewhere. There is a reported location south of the NTS but all other collections are from the NTS. Monitoring will continue for this species and new sites will be recorded as they are found.

\subsubsection{Ivesia arizonica var. saxosa}

Ivesia arizonica var. saxosa is a perennial herb growing in clumps in crevices of cliffs and cracks in boulders (Figure 5-4). Plant clumps are 10-20 $\mathrm{cm}$ (4-8 in) in diameter. It flowers and sets seed in late spring to summer, making June and July the optimum time for field surveys. I. arizonica var. saxosa has small white flowers differentiating it from I. arizonica var. arizonica which has yellow flowers.

I. arizonica var. saxosa is known from two locations on the NTS. One is in Columbine Canyon which is a side canyon of the southern extension of Silent Canyon, west and south of Pahute Mesa Road in Area 19. It has also been reported from Shoshone Mountain in Area 29. The elevation at Columbine Canyon is 1,981 meters $(\mathrm{m})(6,500$ feet $[\mathrm{ft}])$.

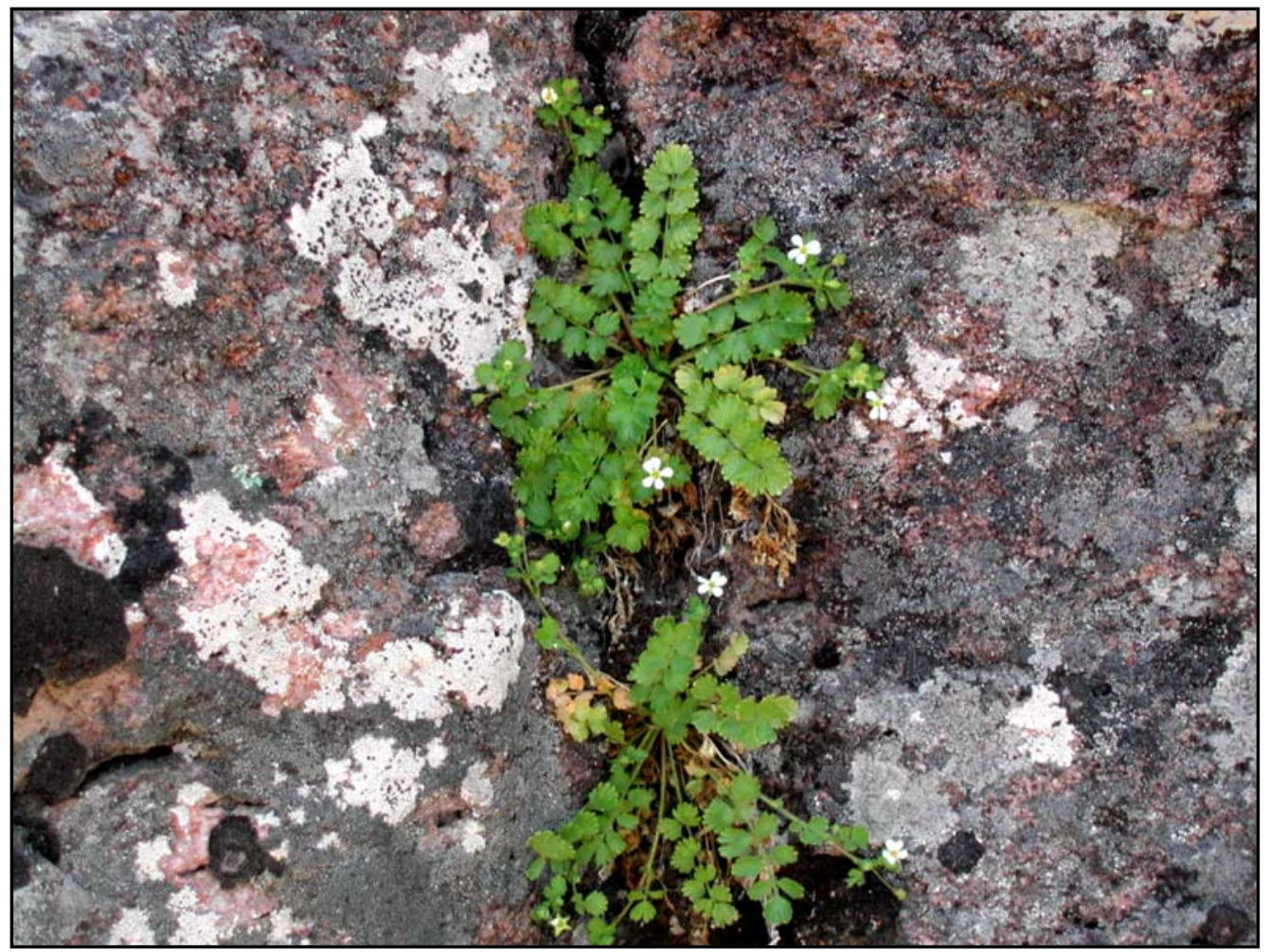

Figure 5-4. Ivesia arizonica var. saxosa growing in cracks of boulders in Columbine Canyon. (Photo by D. Anderson, September 15, 2004). 
The goals of this year's efforts for this species were to first confirm the presence of the species at the known population sites, identify any potential threats to the species, estimate the number of plants present at each of the sites, and as time permitted during the survey window, conduct surveys of potential habitat. Meandering transects were walked through typical habitat. No permanent transects were established. Coordinates were recorded and the number of plants at each location was estimated. No plant density data have been reported for this species in previous years. Habitat characteristics were recorded including slope, aspect, associated species and potential threats to the species, if any were evident.

Surveys were conducted at the Columbine Canyon location and in potential habitat in lower (northern) Lamb's Canyon. No surveys were conducted in the vicinity of Shoshone Mountain. Surveys at Lamb Canyon and Columbine Canyon were conducted in late June. Approximately 150 plants were found at Columbine Canyon (Table 5-2) growing in the cracks of large boulders common along the edges of the canyon (see Figure 5-4). The majority of the plants were found on north-facing walls of the canyon. At the time of the surveys plants were in flower. Potential habitat for this species was observed along the walls of Lamb's Canyon during previous EMAC activities. Surveys were conducted in the northern end of Lamb's Canyon for this species, but the only species encountered was I. arizonica var. arizonica.

Table 5.2 Characteristics of Ivesia arizonica var. saxosa habitat on the NTS.

\begin{tabular}{|c|c|}
\hline \hline Habitat Feature & Columbine Canyon \\
\hline Elevation & $\begin{array}{c}1,966-1,981 \mathrm{~m} \\
(6,450-6,500 \mathrm{ft})\end{array}$ \\
\hline Vegetation Association ${ }^{1}$ & Pinyon Pine/ Sagebrush \\
\hline Soils & Boulders \\
\hline Slope & $35 \%+$ \\
\hline \multicolumn{2}{|c|}{${ }^{+}$} \\
\hline${ }^{1}$ Classification as per Ostler et al., 2000. \\
${ }^{2}$ Number of individuals estimated during site visit
\end{tabular}

Monitoring efforts in future years will focus on areas of potential habitat and the establishment of permanent monitoring transects. There has not been a comprehensive survey on the NTS for I. arizonica var. saxosa, so its distribution is unknown. Potential habitat for this species as been identified at several locations on the NTS. These areas and known population locations in the Shoshone Mountains, will be the focus of future monitoring efforts. Once its distribution on the NTS is better defined, permanent transects will be established at known locations as part of the long-term monitoring program for this species. 


\subsubsection{Lathyrus hitchcockianus}

Lathyrus hitchcockianus is a perennial forb with bluish-green foliage and lax, climbing stems. Stems may reach 30-36 cm (12-14 in) with a terminal, often splitting tendril. The flowers are pea-like in appearance and are rose-lavender to lilac-purple. The plants are in flower in the spring making April and May the best times for surveys. L. hitchcockianus is known from the Pinyon Pass area less than 1.6 kilometer $(\mathrm{km})(1.0$ miles [mi]) west of the NTS western boundary in Area 25.

The goals of this year's efforts for this species were to confirm the presence of the species at the Pinyon Pass location, estimate the number of plants present at the site, and become familiar with its habitat. A meandering transect was walked through the known population location. No permanent transects were established. Coordinates were recorded and the number of plants was estimated. Habitat characteristics were recorded as were potential threats to the species, if any were evident. It was important to become familiar with the habitat and to determine if such habitat occurs on the NTS. If potential habitat can be identified, these areas would then become the focus of future monitoring efforts. Also once biologists are aware of the habitat requirements of this species, they can identify potential habitat during other EMAC activities.

A survey was conducted in the Pinyon Pass area on May 25, 2004. Two different groups of plants were found within $91 \mathrm{~m}$ (100 yards [yd]) of each other. There were approximately 20-30 plants at one site and about 200 plants at the other (Table 5-3). Only a few flowers were evident. Plants were growing on rocky side-slopes and in the bottom of rocky drainage channels (Figure 5-5) on south-facing slopes.

Table 5-3 Characteristics of Lathryus hitchcockianus habitat near the NTS.

\begin{tabular}{|c|c|}
\hline \hline Habitat Feature & Pinyon Pass \\
\hline Elevation & $\begin{array}{c}1,692-1,707 \mathrm{~m} \\
(5,550-5,600 \mathrm{ft})\end{array}$ \\
\hline Vegetation Association $^{1}$ & $\begin{array}{c}\text { Burned, previously Pinyon } \\
\text { Pine/ Sagebrush }\end{array}$ \\
\hline Soils & Rocky, clay \\
\hline Slope & $10 \%$ \\
\hline Plant Abundance & $220-230$ \\
\hline \hline
\end{tabular}

${ }^{1}$ Classification per Ostler et al., 2000.

${ }^{2}$ Number of individuals estimated during site visits 


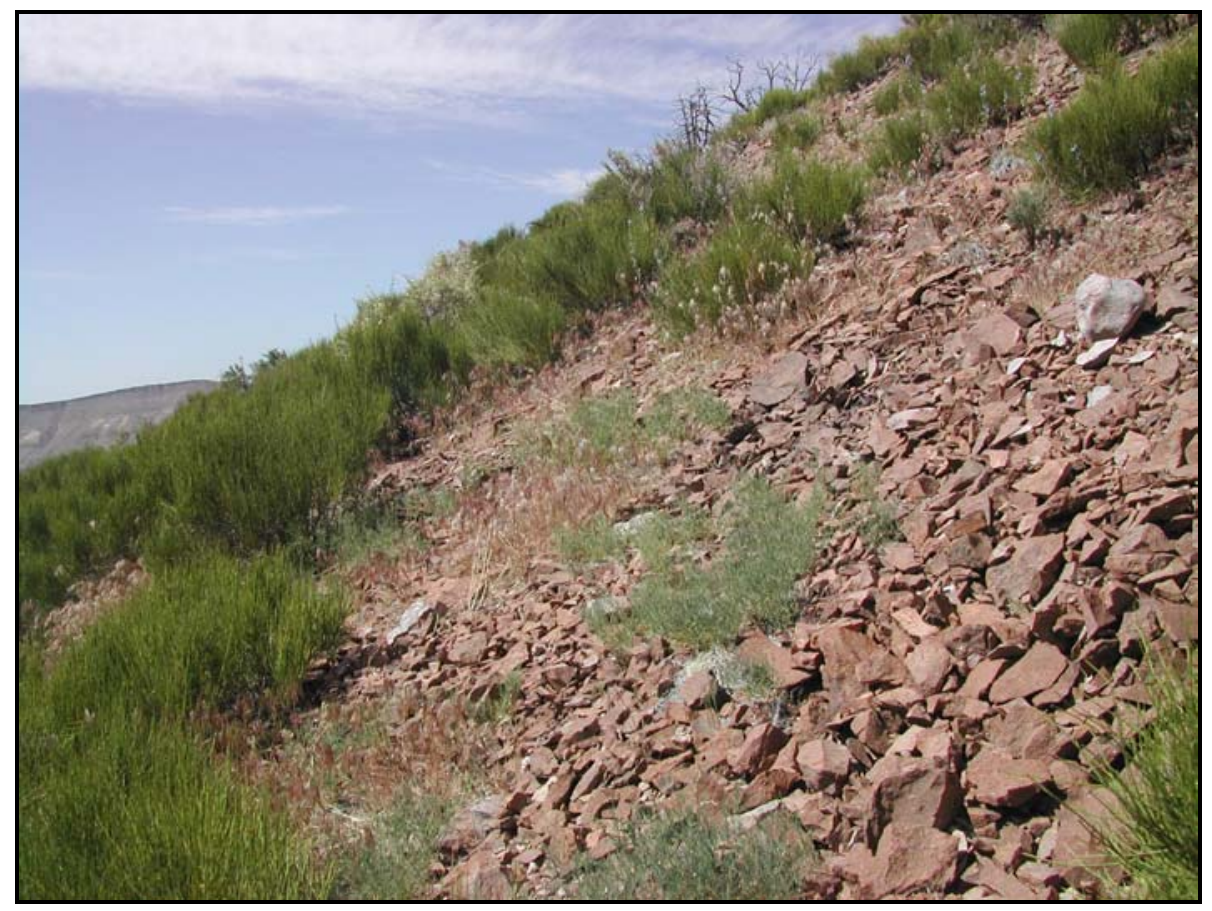

Figure 5-5. Loose rocky habitat for Lathryus hitchcockianus near Pinyon Pass just west of the NTS boundary.

(Photo by D. Anderson, September 15, 2004).

Several other drainages in the area were surveyed but no plants of L. hitchcockianus were found. This particular location at Pinyon Pass appears to be the eastern-most extension of the distribution of this species. Biologists are now aware of the habitat preferences for L. hitchcockianus and future efforts will focus on identifying potential habitat for this species within the boundaries of the NTS.

\subsubsection{Miscellaneous Observations}

Over the last couple of years the slopes of French Peak and the slopes of Shoshone Mountain have been the focus of surveys for Astragalus funereus. Of particular interest was the western slope of Shoshone Mountain where a relatively large population of the species had been reported during surveys conducted in the early 1990s. The site was surveyed last year but no A. funereus was found. This year, surveys were conducted again in the same area with nearly the same results. Several specimens of an Astragalus were found along the tops of several ridges. It was determined not to be A. funereus. Based on these results it is unlikely that $A$. funereus is located on the western slope of Shoshone Mountain. There was a specimen of A. funereus found on the eastern slope of Shoshone Mountain in 2003 and there are reported locations on the southern slopes of French Peak. These sites will become the focus for long-term monitoring of this species.

A single population of Eriogonum hermanii var. clokeyi, along Mercury Ridge just north and west of Mercury, was visited in August of this year. The objective was to confirm its presence at this previously recorded location and to become familiar with the characteristics of this variety as compared to several other varieties of the same species. Several specimens of $E$. hermanii var. clokeyi were found along Mercury Ridge. This species will be included in future sensitive species monitoring activities. 


\subsubsection{Coordination With Natural Resource Agency Botanists}

The 2004 Nevada Rare Plant Workshop was held in Reno, Nevada on April 1, 2004. The Workshop was co-sponsored by the Nevada Native Plant Society (NNPS) and the NNHP. The workshop was hosted by the Bureau of Land Management and the FWS in Reno. Participants included state and federal agency representatives, academia, land resource managers and private concerns. The workshop provides an opportunity for resource agencies to coordinate their efforts to protect rare plant species and to make recommendations regarding species that may need, or no longer need, protection under state or federal laws and regulations.

No action was taken during the workshop that would affect the status of sensitive or rare plant species known to occur on the NTS. One species, Arabis dispar, is being recommended for the NNPS marginal list, mainly because there are only 6-20 occurrences reported for this species. The species has been reported on the NTS in the vicinity of Captain Jack Spring and at two other locations in Nevada. Although its distribution is limited in Nevada it is known from numerous locations in the desert mountains of California. Another species (Petalonyx thurberi ssp. gilmanii), known to occur in Death Valley and suspected to occur in Nevada at a sand dune area just south and west of the NTS, is being considered for the NNPS marginal list. BN botanists were asked to visit the sand dune area to determine if $P$. thurberi ssp. gilmanii occurs there. A visit was made to the dunes in May 2004, but the subspecies gilmanii was not found. Other potential sites for this species in Nevada may be searched in the future, but until a location in Nevada is confirmed, it is unlikely that the NNHP will take any action.

\subsection{Sensitive and Protected/Regulated Animal Species}

In FY/CY 2004, the definition of sensitive animal species was revised to include those species that occur on the NNHP Sensitive Animal List and bat species with a high or moderate ranking in the Nevada Bat Conservation Plan Bat Species Risk Assessment. Species that are not sensitive but are protected or regulated by federal or state law are now considered protected/regulated species (see Table 2-1 shown previously). An annual review of the NNHP Sensitive Animal List and other sources (e.g., FWS list of species of concern, Federal Register, etc.) will be conducted to determine if the Sensitive and Protected/Regulated Animal Species List for the NTS needs to be updated. Other species (e.g., species on NNHP Watch List) may be added to this list if NTS biologists deem appropriate. Two species, the chuckwalla (Sauromalus obesus) and the Gray Flycatcher (Empidonax wrightii) known to occur on NTS, were dropped from the list of NTS sensitive animals, while the mollusk, the southeast Nevada spring snail (Pyrgulopsis turbatrix) and several species of birds; the Northern Goshawk (Accipiter gentilis), Swainson's Hawk (Buteo swainsoni), the Common Loon (Gavia immer), and the Western Yellow-billed cuckoo (Coccyzus americanus occidentalis), were added to the list.

Only one sensitive and federally protected bird, the threatened Bald Eagle (Haliaeetus leucocephalus) has been recently sighted on the NTS. In addition, the sensitive and formerly threatened Peregrine Falcon (Falco peregrinus anatum) has also been observed on the NTS. Other sensitive bird species observed include the uncommon Ferruginous Hawk (Buteo regalis), the White-faced Ibis (Plegadis chihi), and the rare Western Least Bittern (Ixobrychus exillis hesperus). Most of these species are considered uncommon transients through the NTS and are not expected to be impacted by NTS activities. Only two sensitive species of birds, the Burrowing Owl (Athene cunicularia) and Swainson's Hawk, are known to breed on the NTS.

No specific bird surveys were conducted in FY/CY 2004, however, opportunistic sightings of raptors, and resident and migratory birds were made at water sources and other habitats. In FY/CY 2004 specific field surveys of sensitive and protected/regulated animals were restricted to bats and feral horses. Surveys of 
tunnels, mine shafts, mine adits, buildings and water sources were conducted to identify roosts and the annual horse census was also conducted.

\subsubsection{Western Burrowing Owl}

Western Burrowing Owl monitoring was not conducted this year. However, one new burrow site with two burrow openings was found opportunistically in Yucca Flat just south of Sedan Crater. This makes a total of 120 known Western Burrowing Owl locations (30 owl sightings and 90 burrow sites) on the NTS.

\subsubsection{Sensitive Bat Species}

The list of sensitive bat species (see Table 2-1, shown previously) has been changed in FY/CY 2004. The species of concern designation has been dropped so there are now 12 sensitive bat species that are ranked as "high" or "moderate" according to the Bat Species Risk Assessment in Nevada (Nevada Bat Conservation Plan, Altenbach et. al., 2002). This assessment is adapted from Western Bat Species: Regional Priority Matrix (Western Bat Working Group, 1998). The "high" designation is defined as follows, "Based on available information on distribution, status, ecology, and known threats, this designation should result in these species being considered the highest priority for funding, planning, and conservation actions. Information about status and threats to most species could result in effective conservation actions being implemented should a commitment to management exist. These species are imperiled or are at high risk of imperilment." The "moderate" designation is defined as, "This designation indicates a level of concern that should warrant closer evaluation, more research, and conservation actions of both the species and possible threats. A lack of meaningful information is a major obstacle in adequately assessing these species' status and should be considered a threat."

In FY/CY 2004, 60 sites were monitored for bat use between February 19 and September 23 (Figure 5-6). Of these sites, 18 were water sources, 41 were potential roost sites, and one site was a ridgeline near a shaft. A total of 72 surveys were conducted because some sites were sampled multiple times. A total of 134 identified bats representing 7 sensitive and 2 non-sensitive species were captured, and 10,897 electronic files representing 10 sensitive and 3 non-sensitive species were analyzed. Several hundred files from Site J-11 have not been analyzed yet. These will be analyzed in the coming year.

A variety of techniques were used to monitor bat activity. These included direct capture with mist nets, recording ultrasonic echolocation calls using the Anabat $\mathrm{II}^{\mathrm{TM}}$ system (Titley Electronics, Ballina, Australia), recording bat activity with a special night vision camera equipped with NightSight ${ }^{\mathrm{TM}}$ technology attached to a camcorder, and observing bat activity with night vision goggles. The purchase of a new mobile Anabat $\mathrm{II}^{\mathrm{TM}}$ system last year made it possible to monitor two sites at the same time which made sampling much more cost-effective. Generally, the mobile system was set up at one site and a biologist would watch the tunnel, shaft, or adit opening with night vision goggles and another biologist would monitor another site with the NightSight ${ }^{\mathrm{TM}}$ camera and an Anabat II ${ }^{\mathrm{TM}}$ system hooked up to a laptop computer. Calls recorded with the Anabat $\mathrm{II}^{\mathrm{TM}}$ systems were submitted to O'Farrell Biological Consulting for analysis and species identification. Data collected from bat monitoring expand the known distribution and identify critical habitat for bats on the NTS.

\subsubsection{Bat Occurrence at Water Sources}

Of the 18 water sources monitored, 13 were human-made and 5 were natural. Some sites were monitored multiple times for a total of 28 surveys. Results show that 81 individual bats representing 7 sensitive species and 3 non-sensitive species were captured (Table 5-4). Four species, namely; California myotis (Myotis californicus), long-legged myotis (M. volans), small-footed myotis (M. ciliolabrum), and western 


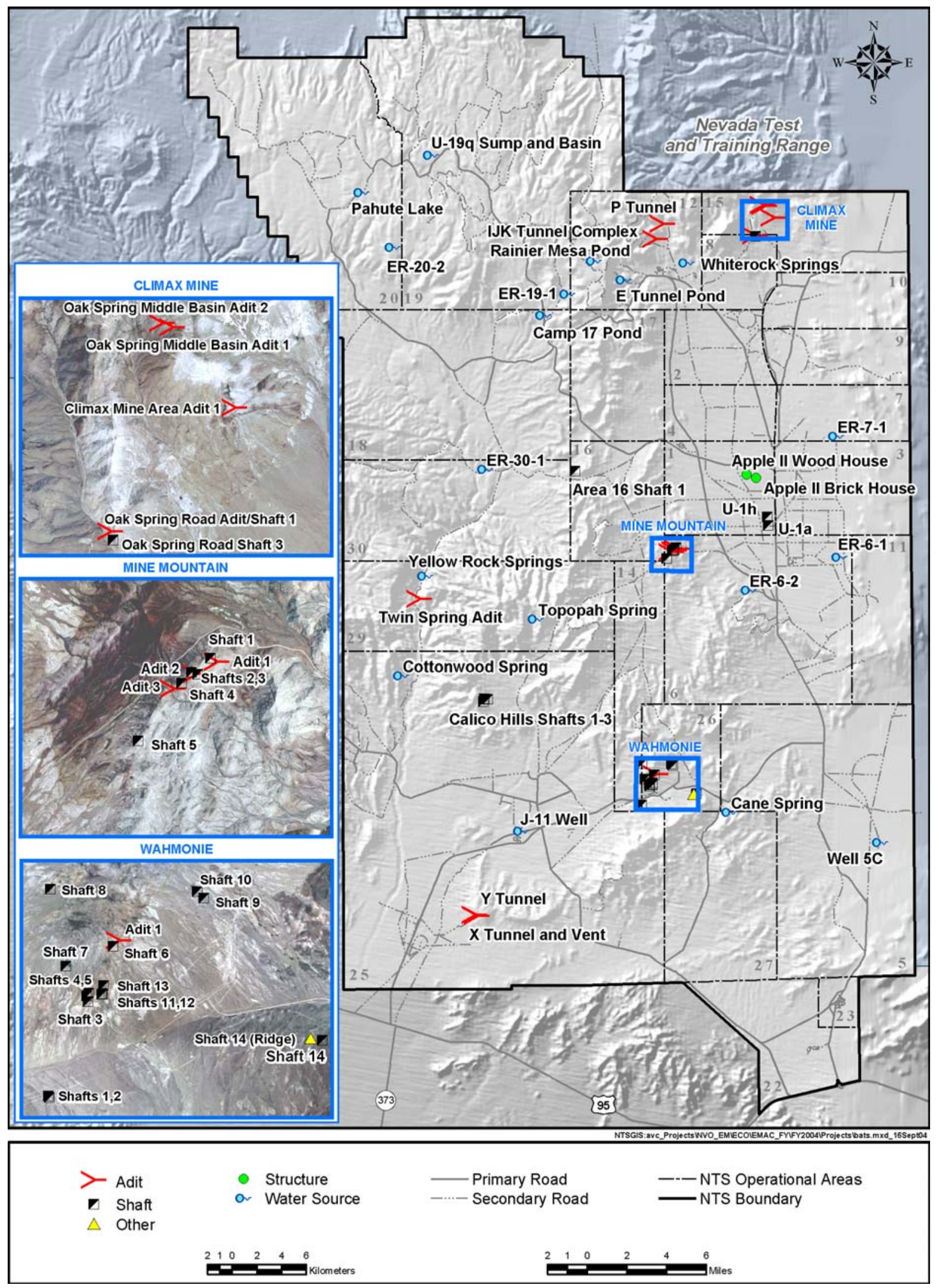

Figure 5-6. Sites monitored for bat activity during FY/CY 2004. 
Table 5-4. Number of bats captured by sex and reproductive condition* (in italics) and number of electronic files of bat calls (regular font) at water sources monitored in FY/CY 2004.

\begin{tabular}{|c|c|c|c|c|c|c|c|c|c|c|c|c|c|c|c|}
\hline \multirow[b]{2}{*}{$\begin{array}{c}\text { Location } \\
\text { (Monitoring Dates) }\end{array}$} & \multicolumn{15}{|c|}{ Species } \\
\hline & 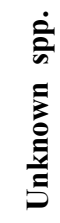 & 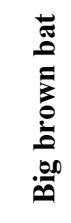 & 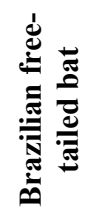 & 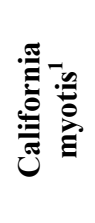 & 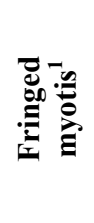 & 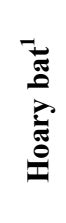 & 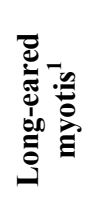 & 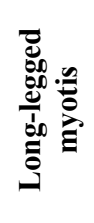 & 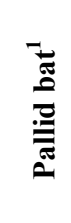 & 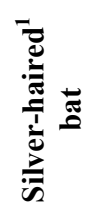 & 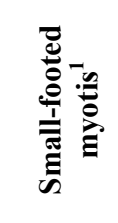 & 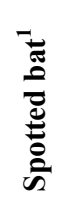 & 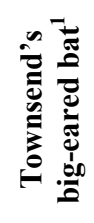 & 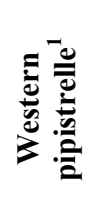 & 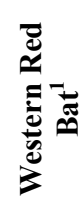 \\
\hline $\begin{array}{l}\text { Camp } 17 \text { Pond }(2 / 19,3 / 9 \text {, } \\
3 / 15)\end{array}$ & & 5 & 48 & 6 & & & & & & & 10 & A & & 14 & \\
\hline $\begin{array}{l}\text { Rainier Mesa Pond }(4 / 6,4 / 6- \\
5 / 4)\end{array}$ & & & 11 & 8 & 6 & 77 & & 22 & 1 & 28 & 186 & & 3 & & \\
\hline Whiterock Spring $(4 / 19,6 / 8)$ & 1 & & & 4 & & & & & & & $1 M, 26$ & & $1 U$ & 4 & \\
\hline $\begin{array}{l}\text { ER U19q Plastic-lined Sump } \\
(4 / 26)\end{array}$ & & 11 & & 1 & & & & & 29 & & 200 & & & & \\
\hline $\begin{array}{l}\text { ER 20-2 Plastic-lined Sump } \\
(5 / 3)\end{array}$ & & & 12 & & 2 & & & & 7 & & 85 & & & 21 & \\
\hline $\begin{array}{l}\text { ER 30-1 Plastic-lined Sump } \\
(5 / 4)\end{array}$ & & & 76 & 106 & 34 & 74 & & & $\begin{array}{c}1 F \\
1 U \\
23\end{array}$ & & $1 F, 235$ & & & 299 & 1 \\
\hline $\begin{array}{l}\text { ER 19-1 Plastic-lined Sump } \\
(5 / 5)\end{array}$ & & & & & 1 & 5 & 7 & & 6 & & 19 & & & 9 & \\
\hline \multicolumn{16}{|l|}{$\begin{array}{l}\text { U2gg Plastic-lined Sump } \\
(5 / 10)\end{array}$} \\
\hline \multicolumn{16}{|l|}{$\begin{array}{l}\text { U2gg Plastic-lined Sump } \\
(5 / 11)\end{array}$} \\
\hline $\begin{array}{l}\text { ER 7-1 Plastic-lined and } \\
\text { Earthen Sumps }(5 / 18)\end{array}$ & & & 1 & 46 & & 12 & & & 5 & & 93 & & & 58 & \\
\hline
\end{tabular}


Table 5-4 (Continued)

\begin{tabular}{|c|c|c|c|c|c|c|c|c|c|c|c|c|c|c|c|}
\hline \multirow[b]{2}{*}{$\begin{array}{c}\text { Location } \\
\text { (Monitoring Dates) }\end{array}$} & \multicolumn{15}{|c|}{ Species } \\
\hline & 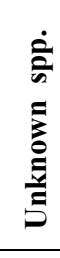 & 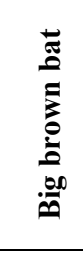 & 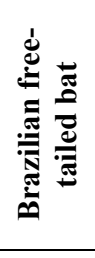 & 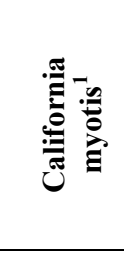 & 氞 & 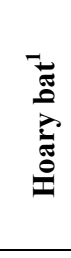 & 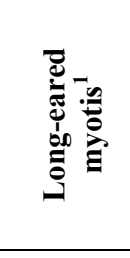 & 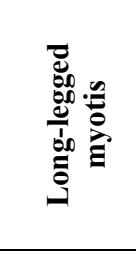 & 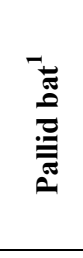 & 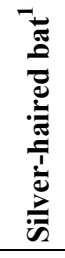 & 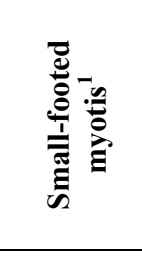 & 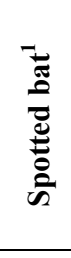 & 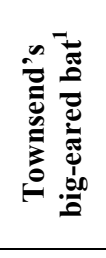 & 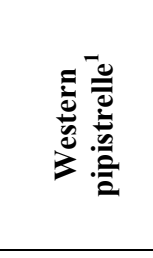 & 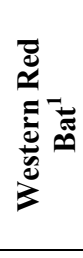 \\
\hline Yellow Rock Springs (5/24) & & & & & & & & & 2 & & & & & 25 & \\
\hline Cottonwood Spring $(5 / 26)$ & & & & 2 & & & & & & & & & & 46 & \\
\hline Topopah Spring (6/1) & 1 & & & $1 M, 36$ & 7 & & & & & & 50 & & & 2 & \\
\hline Cane Spring (6/7) & & & & 29 & & & & & & & & & & 7 & \\
\hline Well 5C (6/10) & 2 & & & $\begin{array}{c}10 L, 3 P \\
2 F, 4 M, \\
324\end{array}$ & & & & & 3 & & & & & $\begin{array}{l}3 P, 2 F \\
4 M, 213\end{array}$ & \\
\hline Pahute Lake (8/11) & & 42 & & 125 & 108 & & 16 & $2 M, 165$ & $\begin{array}{c}1 U \\
34\end{array}$ & & $1 J F, 579$ & A & 2 & $\begin{array}{l}1 J M, 1 J F \\
635\end{array}$ & \\
\hline ER 6-1 Sump (8/31) & & & 4 & 81 & & & & & 3 & & 17 & & & 232 & \\
\hline ER 6-2 Sump (9/1) & & & 10 & 28 & & & & & & & 2 & & & 245 & \\
\hline $\begin{array}{c}\text { E Tunnel Pond }(8 / 30,9 / 8, \\
9 / 13,9 / 16)\end{array}$ & & $\begin{array}{l}1 M \\
49\end{array}$ & 9 & $1 M, 56$ & $\begin{array}{l}3 M \\
110\end{array}$ & 3 & $\begin{array}{c}1 F, 1 M \\
34\end{array}$ & $\begin{array}{l}3 F, 2 M \\
412\end{array}$ & 20 & & $\begin{array}{l}9 F, 2 M \\
449\end{array}$ & & 7 & $\begin{array}{l}5 F, 1 J F \\
1 M, 1 U \\
\quad 987\end{array}$ & \\
\hline J-11 Well ${ }^{2}(9 / 20,9 / 23)$ & & & $1 F$ & & & & & & & & & & & $6 F, 3 M$ & \\
\hline Total Number of Captures & 4 & 1 & 1 & 21 & 3 & 0 & 2 & 7 & 3 & 0 & 14 & $2 \mathrm{~A}$ & 1 & 28 & 0 \\
\hline $\begin{array}{c}\text { Total Number of Electronic } \\
\text { Files }\end{array}$ & & 107 & 171 & 852 & 268 & 171 & 57 & 599 & 133 & 28 & 2,531 & 0 & 12 & 2,797 & 1 \\
\hline
\end{tabular}

${ }^{1}$ Sensitive species (see Table $2-1$ ); ${ }^{2}$ Anabat data not yet analyzed; A=audible call, presumably spotted bat call

$\mathrm{F}=$ Female, $\mathrm{LF}=$ Lactating female, $\mathrm{P}=$ Pregnant female $\mathrm{JF}=$ Juvenile Female, $\mathrm{M}=$ Male, JM=Juvenile Male, $\mathrm{U}=\mathrm{Unknown}$ gender 
pipistrelle (Pipistrellus hesperus) showed evidence of breeding, as reproductive (pregnant or lactating) females and juveniles were captured. Four bats were caught in the mist nets but escaped before identification was possible. Audible calls, presumably made by spotted bats, were heard at Camp 17 Pond and Pahute Lake. Results from the analysis of 7,121 files reveal the presence of 10 sensitive species and 3 non-sensitive species. Additional species may be detected from the files that have not yet been analyzed. With the audible spotted bat call, 14 bat species were detected, including 11 sensitive and 3 non-sensitive species. Some species (hoary bat [Lasiurus cinereus], silver-haired bat [Lasionycteris noctivagans] and western red bat $[L$. blossevillii]) were detected acoustically but not captured (see Table 5-4). This shows the importance of using a combination of techniques to detect bats. Bats were detected at all sites except U2gg Sump, presumably due to high winds and stormy conditions.

\subsubsection{Bat Occurrence at Potential Roost Sites}

Of the 41 potential roost sites monitored, 26 were shafts, 9 were adits, 4 were tunnels, and 2 were buildings. Some sites were monitored multiple times for a total of 44 surveys including the ridge near Wahmonie Shaft 14. A total of 49 individual bats representing 3 sensitive species were captured. Several captured Townsend's big-eared bats and fringed myotis (M. thysanodes) were reproductive females or juveniles. In addition, 4 bats were caught in the mist nets but escaped before identification was possible. Results from the analysis of 3,776 files reveal the presence of 7 sensitive species and 2 non-sensitive species (Table 5-5). California myotis, small-footed myotis, and western pipistrelles were the most frequently detected species. It is interesting to note that only 3 species were captured but 9 species were detected acoustically (Table 5-5). This is partially due to the fact that it is difficult to capture bats with mist nets at shafts and large tunnel openings. In fact, mist nets were not set up at many shafts or large tunnel openings.

Although not a potential roost site, the ridge by Wahmonie Shaft 14 was sampled to compare bat activity at a random location with bat activity at a shaft. Results from both sites were very similar and no bats were seen going into the shaft, suggesting that the shaft did not attract bats any more than a random location.

\subsubsection{Identification of Roost Sites}

Bats are known to have day roosts where they remain from dawn until dusk and night roosts where they rest between foraging forays. Maternity roosts are sites where females give birth and rear their young. Some maternity roosts are communal, containing large colonies of one or more species of bats. The young remain in the roost until they are weaned, and lactating females leave the roost only to forage.

Data from mist net captures, review of recorded video tapes, visual observations, and acoustic data were all examined to determine bat use designations for the potential roost sites monitored. These designations included: $\mathrm{M}=$ maternity roost where lactating females or juveniles were captured in mist nets and bats were also seen exiting the site near dusk, $\mathrm{D}=$ day roost where bats were observed flying out of the site near dusk, N/FS=night roost and/or foraging site where bats were observed flying in and out of or foraging within the site, and $\mathrm{I}=$ indeterminate use where bats were only observed flying over or around the site and not flying in or out of it. Of the 
Table 5-5. Number of bats captured by sex and reproductive condition* (in italics) and number of electronic files of bat calls (regular font) at potential roost sites monitored in FY/CY 2004.

\begin{tabular}{|c|c|c|c|c|c|c|c|c|c|c|}
\hline \multirow[b]{2}{*}{ Location (Monitoring Dates) } & \multicolumn{10}{|c|}{ Species } \\
\hline & 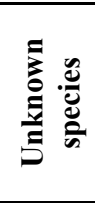 & 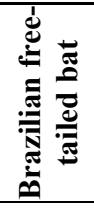 & 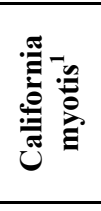 & 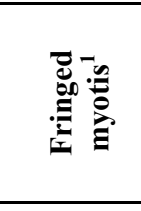 & 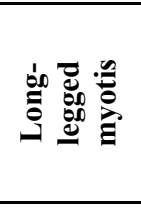 & 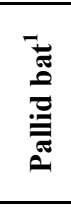 & 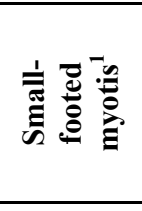 & 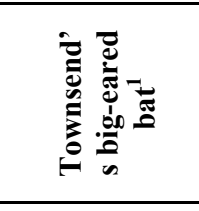 & 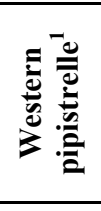 & 氞 \\
\hline Twin Spring Adit (6/2) & 1 & & 11 & $\begin{array}{l}6 L F, 1 F \\
3 M, 101\end{array}$ & & & 6 & $\begin{array}{c}6 L F, 1 F, 1 M \\
3 U, 24\end{array}$ & 3 & \\
\hline Wahmonie Shafts 1 and $2(6 / 14)$ & & & 3 & & & & & & 7 & \\
\hline Wahmonie Shaft $9(6 / 21)$ & & & 1 & & & & & & 1 & \\
\hline Wahmonie Shaft $10(6 / 21)$ & & & 1 & & & & & & & \\
\hline Wahmonie Adit 1 (6/22) & & & 3 & & & & & & 1 & \\
\hline Wahmonie Shaft $6(6 / 22)$ & & & & & & & & & 4 & \\
\hline Wahmonie Shaft $4(6 / 23)$ & & & 3 & & & & & & 15 & \\
\hline Wahmonie Shaft $5(6 / 23)$ & & & & & & & & & 6 & \\
\hline Calico Hills Shaft 1 (6/28) & & & 3 & & & & & & 6 & \\
\hline Calico Hills Shaft $2(6 / 28,6 / 29)$ & & & 7 & & & 1 & & & 4 & \\
\hline Calico Hills Shaft 3 (6/29) & & & 2 & & & & & & 4 & \\
\hline Wahmonie Shafts 11 and $12(6 / 30)$ & & & 3 & & & & & & 6 & \\
\hline Wahmonie Shaft $13(6 / 30)$ & & & & & & & & & 4 & \\
\hline Wahmonie Shaft $3(7 / 6)$ & & & 4 & & & 1 & 1 & & 4 & \\
\hline Wahmonie Shaft 7 (7/7) & & & 3 & & & & & & 5 & \\
\hline Wahmonie Shaft $8(7 / 7)$ & & & 4 & & & & & & 9 & \\
\hline
\end{tabular}


Table 5-5. (Continued)

\begin{tabular}{|c|c|c|c|c|c|c|c|c|c|c|}
\hline \multirow[b]{2}{*}{ Location (Monitoring Dates) } & \multicolumn{10}{|c|}{ Species } \\
\hline & 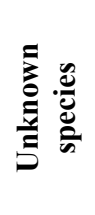 & 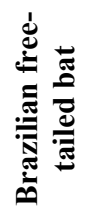 & 我 & 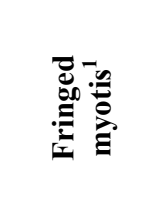 & 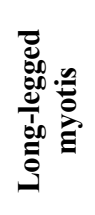 & 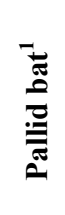 & 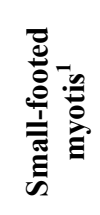 & 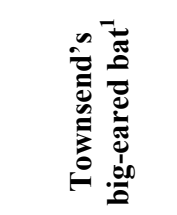 & 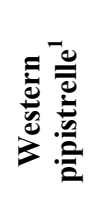 & 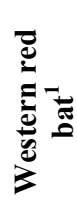 \\
\hline $\begin{array}{l}\text { Climax Mine Area Adit } 1 \text { (7/12, 1/14- } \\
3 / 31)\end{array}$ & & & 369 & $\begin{array}{l}2 L F, 1 J F \\
5 M, 82\end{array}$ & & 21 & 30 & $4 L F, 1 F$ & & \\
\hline Oak Spring Middle Basin Adit 1 (7/13) & & & 15 & 6 & 1 & 15 & 6 & $\begin{array}{c}1 L F, 3 J F \\
6 J M, 2 U, 24\end{array}$ & 1 & \\
\hline Oak Spring Middle Basin Adit 2 (7/13) & & & 36 & 2 & & 1 & 14 & 7 & 97 & 1 \\
\hline Oak Spring Road Adit/Shaft 1 (7/14) & 3 & & 8 & $1 J M, 3$ & & 2 & $1 F, 7$ & $1 M$ & 7 & \\
\hline Oak Spring Road Shaft $3(7 / 14)$ & & & 119 & & & & 1 & 2 & 13 & \\
\hline Area 16 Shaft $1(7 / 19)$ & & & & & & 1 & & & 8 & \\
\hline Mine Mountain Adit $1(7 / 20,8 / 2)$ & & & 9 & & & & & & 3 & \\
\hline \multicolumn{11}{|l|}{ Mine Mountain Shaft $1(7 / 20,8 / 2)$} \\
\hline Wahmonie Shaft 14 (7/22) & & & & & & & & & 13 & \\
\hline Wahmonie Shaft 14 Ridge (7/22) & & & & & & & & & 11 & \\
\hline Mine Mountain Adit $2(7 / 26)$ & & & 10 & & & & & & 5 & \\
\hline Mine Mountain Shaft $3(7 / 26)$ & & & 6 & & & 2 & & & 4 & \\
\hline Mine Mountain Adit $3(7 / 27)$ & & & 13 & & & & 2 & & 4 & \\
\hline Mine Mountain Shaft $5(7 / 27)$ & & & & & & & & & 18 & \\
\hline Mine Mountain Shaft $2(8 / 3)$ & & & 1 & & & & & & 1 & \\
\hline
\end{tabular}


Table 5-5. (Continued)

\begin{tabular}{|c|c|c|c|c|c|c|c|c|c|c|}
\hline \multirow[b]{2}{*}{ Location (Monitoring Dates) } & \multicolumn{10}{|c|}{ Species } \\
\hline & 战 & 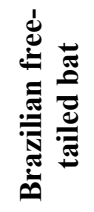 & & 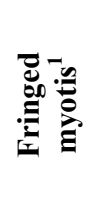 & 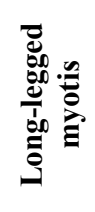 & 咅 & 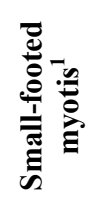 & 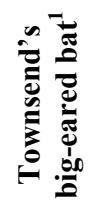 & 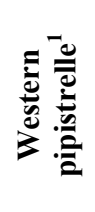 & 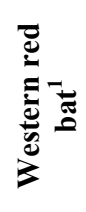 \\
\hline Mine Mountain Shaft $4(8 / 3)$ & & & 3 & & & & & & & \\
\hline Apple II Wood House (8/4) & & & 55 & & & 1 & 27 & & 2 & \\
\hline Apple II Brick House (8/4) & & & 28 & & & 22 & 26 & & 26 & \\
\hline IJK Tunnel Complex (8/9) & & & 85 & & & & 23 & & 7 & \\
\hline$X$ Tunnel $(8 / 10)$ & & & 1 & & & & & & 10 & \\
\hline Y Tunnel $(8 / 10)$ & & & 11 & & & 1 & & & 2 & \\
\hline P Tunnel (9/14) & & 8 & 3 & 1 & & & 617 & & 339 & \\
\hline U1a $(9 / 21)$ & 1 & & & & & & & & & \\
\hline $\mathrm{U} 1 \mathrm{~h}(9 / 21)$ & & 3 & 53 & & & & & & & \\
\hline Total Number of Captures: & 4 & 0 & 0 & 19 & 0 & 0 & 1 & 29 & 0 & 0 \\
\hline Total Number of Electronic Files: & 1 & 11 & 873 & 195 & 1 & 68 & 760 & 57 & 650 & 1 \\
\hline
\end{tabular}

Sensitive species (see Table 2-1)

$\mathrm{F}=$ Female, $\mathrm{LF}=$ Lactating female, $\mathrm{JF}=$ Juvenile Female, $\mathrm{M}=$ Male, $\mathrm{JM}=\mathrm{Juvenile}$ Male, $\mathrm{U}=$ Unknown gender 
41 potential roost sites sampled, 3 are maternity roosts, 6 are day roosts, 12 are night roosts/foraging sites, and 20 are indeterminate (Table 5-6). Bat activity was detected at all sites but one (Mine Mountain Shaft 1). The three maternity colonies are located in Climax Mine Area Adit 1, Oak Spring Middle Basin Adit 1, and Twin Spring Adit. Lactating Townsend's big-eared bats and fringed myotis were captured at both Climax Mine Area Adit 1 and Twin Spring Adit while only lactating Townsend's big-eared bats were captured at Oak Spring Middle Basin Adit 1. These captures confirm that Oak Spring Middle Basin Adit 1 is a maternity colony as was thought last year. The presence of fringed myotis was detected acoustically at Oak Spring Middle Basin Adit 1, suggesting that they may also be roosting inside the adit. Bats have been documented to be roosting in Climax Mine Area Adit 1 and Oak Spring Middle Basin

Adit 1 for at least two years in a row. Several other species were also detected at the three sites: California myotis, small-footed myotis, western pipistrelle, pallid bat (Antrozous pallidus), and longlegged myotis. It is impossible to determine if these species were actually roosting in the adits or just flying over or around the entrance.

\subsubsection{Biota Dose Assessment Monitoring}

A new DOE document, "A Graded Approach for Evaluating Radiation Doses to Aquatic and Terrestrial Biota" (DOE, 2002a) outlines methods to assess radiation doses to biota. E Tunnel Pond is a contaminated, perennial water source at which bats are known to drink and forage. Because bats are relatively long-lived (10 to 20 years) and most species on the NTS do not migrate, there is a potential for these animals to uptake radionuclides through regular drinking and foraging at contaminated sites. Therefore, in conjunction with routine bat monitoring, bats were collected at $\mathrm{E}$ Tunnel Pond to be analyzed for radionuclides. Bats were also collected at a control site, J-11 Pond (Area 25) for comparison. Collected specimens have been sent out for analysis but the results are not back yet. The capture data are also helpful to better define bat distribution on the NTS.

\subsubsection{Reported Day Roosts In Buildings}

Bats in or around buildings were found on six occasions at three buildings in Mercury by NTS workers who then contacted Ecological Services biologists. Six California myotis and one western pipistrelle were identified. Results from biological surveys of buildings and reports by others of bats in buildings enable BN biologists to increase their knowledge about bat roosting sites on the NTS. Roost site locations will continue to be documented and stored in the EGIS faunal database.

\subsubsection{Passive Acoustic Monitoring System}

In order to learn more about long-term bat activity over different seasons and years, a passive acoustic monitoring system was installed at Camp 17 Pond on September 22, 2003. Tens of thousands of electronic files containing bat calls have been recorded and are in the process of being analyzed by O'Farrell Biological Consulting. Data generated by this system are truly unique and will give us a better understanding of bat activity during different seasons. Climatic data are also being recorded to be correlated with bat activity data to help biologists look for patterns of activity under different types of environmental conditions. Because data are still being analyzed, results are not included in this year's report. 
Table 5-6. Bat use designations for all potential roost sites monitored during FY/CY 2004.

\begin{tabular}{|c|c|c|c|}
\hline Location & $\begin{array}{c}\text { Use } \\
\text { Designation }^{1}\end{array}$ & Observations $^{2}$ & $\begin{array}{c}\text { Number } \\
\text { of Species } \\
\text { Present }^{3}\end{array}$ \\
\hline Twin Spring Adit & M & $\begin{array}{l}6 \text { lactating Townsend's big-eared bats and } \\
6 \text { lactating fringed myotis captured, bats } \\
\text { exiting adit at dusk }\end{array}$ & 5 \\
\hline Wahmonie Shafts 1 and 2 & I & Bats flying over shafts & 2 \\
\hline Wahmonie Shaft 9 & I & Bats flying over shaft & 2 \\
\hline Wahmonie Shaft 10 & I & Bats flying over shaft & 1 \\
\hline Wahmonie Adit 1 & I & Bats flying over shaft & 2 \\
\hline Wahmonie Shaft 6 & I & Bats flying over shaft & 1 \\
\hline Wahmonie Shaft 4 & I & Bats flying over shaft & 2 \\
\hline Wahmonie Shaft 5 & I & Bats flying over shaft & 1 \\
\hline Calico Hills Shaft 1 & $\mathrm{D}$ & Bats exiting adit at dusk & 2 \\
\hline Calico Hills Shaft 2 & $\mathrm{~N} / \mathrm{FS}$ & Bats flying in and out of shaft & 3 \\
\hline Calico Hills Shaft 3 & I & Bats flying over shaft & 2 \\
\hline Wahmonie Shafts 11 and 12 & I & Bats flying over shaft & 2 \\
\hline Wahmonie Shaft 13 & I & Bats flying over shaft & 1 \\
\hline Wahmonie Shaft 3 & $\mathrm{~N} / \mathrm{FS}$ & $\begin{array}{l}\text { Bats flying around shaft and landing } \\
\text { briefly on platform covering shaft, possibly } \\
\text { gleaning insects off of platform }\end{array}$ & 4 \\
\hline Wahmonie Shaft 7 & $\mathrm{~N} / \mathrm{FS}$ & $\begin{array}{l}\text { Bat flew into shaft and bats flying over } \\
\text { shaft }\end{array}$ & 2 \\
\hline Wahmonie Shaft 8 & I & Bats flying over shaft & 2 \\
\hline Climax Mine Area Adit 1 & M & $\begin{array}{l}4 \text { lactating Townsend's big-eared bats and } \\
2 \text { lactating fringed myotis captured, bats } \\
\text { exiting adit at dusk }\end{array}$ & 5 \\
\hline Oak Spring Middle Basin Adit 1 & M & $\begin{array}{l}1 \text { lactating Townsend's big-eared bat and } \\
\text { several juveniles captured, cluster of bats } \\
\text { near opening, bats in and out of adit }\end{array}$ & 7 \\
\hline Oak Spring Middle Basin Adit 2 & N/FS & Bats flying in and out of and over adit & 7 \\
\hline Oak Spring Road Adit/Shaft 1 & $\mathrm{D}, \mathrm{N} / \mathrm{FS}$ & $\begin{array}{l}\text { Bats exiting adit at dusk, bats flying in and } \\
\text { out of adit and shaft }\end{array}$ & 6 \\
\hline Oak Spring Road Shaft 3 & $\mathrm{~N} / \mathrm{FS}$ & Bats flying in and out of and over shaft & 4 \\
\hline
\end{tabular}


Table 5-6 (Continued)

\begin{tabular}{|c|c|c|c|}
\hline Location & $\begin{array}{c}\text { Use } \\
\text { Designation }\end{array}$ & Observations $^{2}$ & $\begin{array}{c}\text { Number } \\
\text { of Species } \\
\text { Present }^{3}\end{array}$ \\
\hline Area 16 Shaft 1 & $\mathrm{~N} / \mathrm{FS}$ & Bats flying in and out of and over adit & 2 \\
\hline Mine Mountain Adit 1 & $\mathrm{D}, \mathrm{N} / \mathrm{FS}$ & $\begin{array}{l}\text { Bat exiting adit at dusk, bats flying in and } \\
\text { out of and over adit, bat roosted on ceiling } \\
\text { for over } 15 \text { minutes }\end{array}$ & 2 \\
\hline Mine Mountain Shaft 1 & I & No bats seen & 0 \\
\hline Wahmonie Shaft 14 & I & Bats seen flying over shaft & 1 \\
\hline Wahmonie Shaft 14 Ridge & I & Bats flying over ridge & 1 \\
\hline Mine Mountain Adit 2 & $\mathrm{~N} / \mathrm{FS}$ & Bats flying in and out of and over adit & 2 \\
\hline Mine Mountain Shaft 3 & I & Bats flying over shaft & 3 \\
\hline Mine Mountain Adit 3 & $\mathrm{~N} / \mathrm{FS}$ & Bats flying in and out of adit & 3 \\
\hline Mine Mountain Shaft 5 & I & Bats flying over shaft & 1 \\
\hline Mine Mountain Shaft 2 & I & Bats flying over shaft & 2 \\
\hline Mine Mountain Shaft 4 & I & Bats flying over shaft & 1 \\
\hline Apple II Wood House & $\mathrm{N} / \mathrm{FS}$ & Bats flying in and out of house & 4 \\
\hline Apple II Brick House & $\mathrm{N} / \mathrm{FS}$ & Bats flying in and out of house & 4 \\
\hline IJK Tunnel Complex & $\mathrm{D}, \mathrm{N} / \mathrm{FS}$ & $\begin{array}{l}\text { Bat exiting tunnels at dusk, bats flying in } \\
\text { and out of and around tunnel entrances }\end{array}$ & 3 \\
\hline X Tunnel & $\mathrm{D}, \mathrm{N} / \mathrm{FS}$ & $\begin{array}{l}\text { Bats exiting tunnel at dusk, bats flying in } \\
\text { and out of and over tunnel entrance }\end{array}$ & 2 \\
\hline Y Tunnel & $\mathrm{D}, \mathrm{N} / \mathrm{FS}$ & $\begin{array}{l}\text { Bats exiting tunnel at dusk, bats flying in } \\
\text { and out of and over tunnel entrance }\end{array}$ & 3 \\
\hline P Tunnel & $\mathrm{N} / \mathrm{FS}$ & Bats foraging around tunnel entrance & 5 \\
\hline U1a & I & No bats seen & 0 \\
\hline U1h & $\mathrm{N} / \mathrm{FS}$ & Bats seen flying around shaft & 2 \\
\hline \multicolumn{4}{|c|}{$\begin{array}{l}{ }^{1} \mathrm{D}=\text { day roost, } \mathrm{I}=\text { of indeterminate use, } \mathrm{M}=\text { maternity roost, } \mathrm{N} / \mathrm{FS}=\text { night roost and/or foraging site } \\
{ }^{2} \text { Observations used for designating roost type; based on mist net captures and observations with NightSight }{ }^{\mathrm{TM}} \\
\text { camera and night vision goggles }\end{array}$} \\
\hline
\end{tabular}




\subsubsection{Coordination with Other Wildlife Agencies/Biologists}

A BN biologist attended a meeting of the Nevada Bat Working Group in February 2004. Several state and federal agency personnel were in attendance to discuss issues concerning the Nevada Bat Conservation Plan. Final issues regarding language in the plan that would be acceptable to all signatory agencies were worked out and writing assignments made. A draft plan was distributed in June for review, and the plan should be finalized in late 2004 or early 2005. The BN biologist provided input as one of the contributing authors to the plan, and information from bat monitoring on the NTS was included in the plan. Also, a BN biologist attended the $34^{\text {th }}$ Annual North American Symposium on Bat Research in Salt Lake City, Utah in October 2004, and presented a poster summarizing the results of mine and tunnel surveys for bat activity on the NTS.

\subsubsection{Wild Horses}

Horse monitoring continued this year to provide information on the abundance, recruitment (i.e., survival of horses to reproductive age), and distribution of the horse population on the NTS. Monitoring of individual horses at NTS began in 1989. In FY/CY 2004, BN biologists determined horse abundance and recorded horse sign along roads. Also, selected natural and human-made water sources were visited in the summer to determine their influence on horse distribution and movements and document the impact horses are having on NTS wetlands. Information on abundance and recruitment during 1990-1998 is summarized in Greger and Romney (1999).

\subsubsection{Abundance Survey}

A count of individual horses was taken to estimate abundance. The count was conducted during 13 nonconsecutive days between June and September. A standard road course was driven to locate and identify horses. Individuals were identified by their unique physical markings, and classified as foal, yearling, or older ( $\geq 2$ year old). The direct population count in FY/CY 2004 was 37 individuals not including foals (Table 5-7). Five horse bands (composed of stallions, subordinate males, females, and their offspring) were detected this year. Bands observed ranged in size from 5 to 11 individuals excluding foals. Six foals were observed with their mares from June-August. The population showed a small increase in number over last year due to the recent survival of several younger-aged horses (yearling to two year olds).

The overall trend in the NTS horse population has generally been downward from 1995 to 1998 (Table 5-7). It then stabilized with a slight recovery in one to two year olds in 2003-04. Only 11 yearling horses have been observed in the population from 1995 through 2003. However, during 2003-2004, nine individuals were classified as yearlings (Figure 5-7). The overall population declines from 1995 to 1998 appears to be the result of poor foal survival and no immigration of new adults into the population. Also, older male horses have tended to disappear from the population over time, with only eight males presently observed in the NTS population this year (Table 5-7). Two older adult males are missing this year.

Unidentified remains of older horses (bones and hair) are commonly found in heavily used areas around springs and suggest that the loss of adult males was probably due to mortality as opposed to emigration.

Presently, the surviving population of NTS horses is still somewhat dominated by older-aged individuals (10 to $>16$ years) compared to the younger-aged cohort from 1-7 years old (Figure 5-8). Most of the living males are older horses and mortality of these individuals will be expected to increase in the near future. Over the past ten years, the causes of mortality among adult horses have included predation (one), collisions with vehicles (two), drowning (one), and unknown (four). Among young horses (1-2 year olds), two have died from unknown causes and one presumably from dehydration at a dried-up spring. Many previously identified horses have not been observed for years and are presumed dead. 
Table 5-7. Number of individual horses observed on the NTS by age class, gender, and year since 1995.

\begin{tabular}{|c|c|c|c|c|c|c|c|c|c|c|}
\hline \multirow[b]{2}{*}{ Age Class } & \multicolumn{10}{|c|}{ Number of Individuals Observed by Year } \\
\hline & 1995 & 1996 & 1997 & 1998 & 1999 & 2000 & 2001 & 2002 & 2003 & 2004 \\
\hline Foals & 1 & 1 & 3 & 8 & 5 & 11 & 11 & 5 & 6 & 5 \\
\hline \multirow[t]{2}{*}{ Yearlings } & 3 & 0 & 0 & 0 & 2 & 4 & 2 & 0 & 5 & 4 \\
\hline & $M^{b}: F$ & $\mathbf{M}: \mathbf{F}$ & $\mathbf{M}: \mathbf{F}$ & $\mathbf{M}: \mathbf{F}$ & $M: F$ & $\begin{array}{l:l}\mathbf{M} & \mathbf{F} \\
\end{array}$ & $\mathbf{M}: \mathbf{F}$ & $M: F$ & $\mathbf{M}: \mathbf{F}$ & $\mathbf{M}: \mathbf{F}$ \\
\hline 2 Year & $0: 0$ & $\begin{array}{l:l} & 1\end{array}$ & $\begin{array}{l:l}0 & 0\end{array}$ & $0: 0$ & $0: 0$ & (2) $1: 0$ & $2: 2$ & $0: 2$ & $\begin{array}{l:l}0 & 0\end{array}$ & 2 \\
\hline 3 Year & $0: 0$ & $0: 0$ & $0: 1$ & $0: 0$ & $0: 0$ & $0: 0$ & $0: 0$ & $2: 2$ & $\begin{array}{l:l}0 & 2\end{array}$ & $\begin{array}{l:l}0 & 0\end{array}$ \\
\hline $\begin{array}{c}\text { Adults } \\
\text { ( > } 3 \text { Year Olds) }\end{array}$ & $22: 29$ & $21: 24$ & 20 & $16: 21$ & $11: 20$ & 213 & $\begin{array}{r:r}11 & 20 \\
& \\
& \end{array}$ & $8: 19$ & $8: 20$ & $6: 22$ \\
\hline $\begin{array}{c}\text { Total } \\
\text { (excluding } \\
\text { foals) }\end{array}$ & 54 & 46 & 40 & 37 & 31 & 38 & 37 & 33 & 35 & 37 \\
\hline
\end{tabular}

${ }^{a}$ Number dead shown in parenthesis; ${ }^{b} \mathrm{M}=$ male, $\mathrm{F}=$ female;

\subsubsection{Annual Range Survey}

During FY/CY 2004, selected roads were driven within and along the boundaries of the suspected annual horse range and all fresh sign (estimated to be $<1$ year old) located on and adjacent to the roads were recorded. Eight days of effort were expended for the road surveys. Horse sign data collected during the road surveys and horse use at natural and human-made water sources indicate that the FY/CY 2004 NTS horse range includes Gold Meadows, Yucca Flat, Eleana Range, southwest foothills of the Eleana Range, and southeast Pahute Mesa (Figure 5-9). Overall, the annual horse range appears to be reduced slightly from previous years and totals approximately $316 \mathrm{~km}^{2}\left(122 \mathrm{mi}^{2}\right)$. During the summer, horses are dependent on Captain Jack Spring, the only known water source in the Eleana Range. Several humanmade water sources on Yucca Flat have been removed in past years, and the increased distances horses must travel back and forth to Captain Jack Spring probably limits the herds' grazing range to the north and east. In addition, the risk of mountain lion predation is greater for those horses returning to the Eleana Range to drink.

As in previous years, the horse herd appears to consist of two components; one larger group of horses (about 30 individuals) comprised of four bands that spends summers west of the Eleana Range and one smaller group ( 7 individuals) comprised of one band that summers east of the Eleana Range on Yucca Flat. These groups of horses probably intermix during the winter in the Eleana Range. 


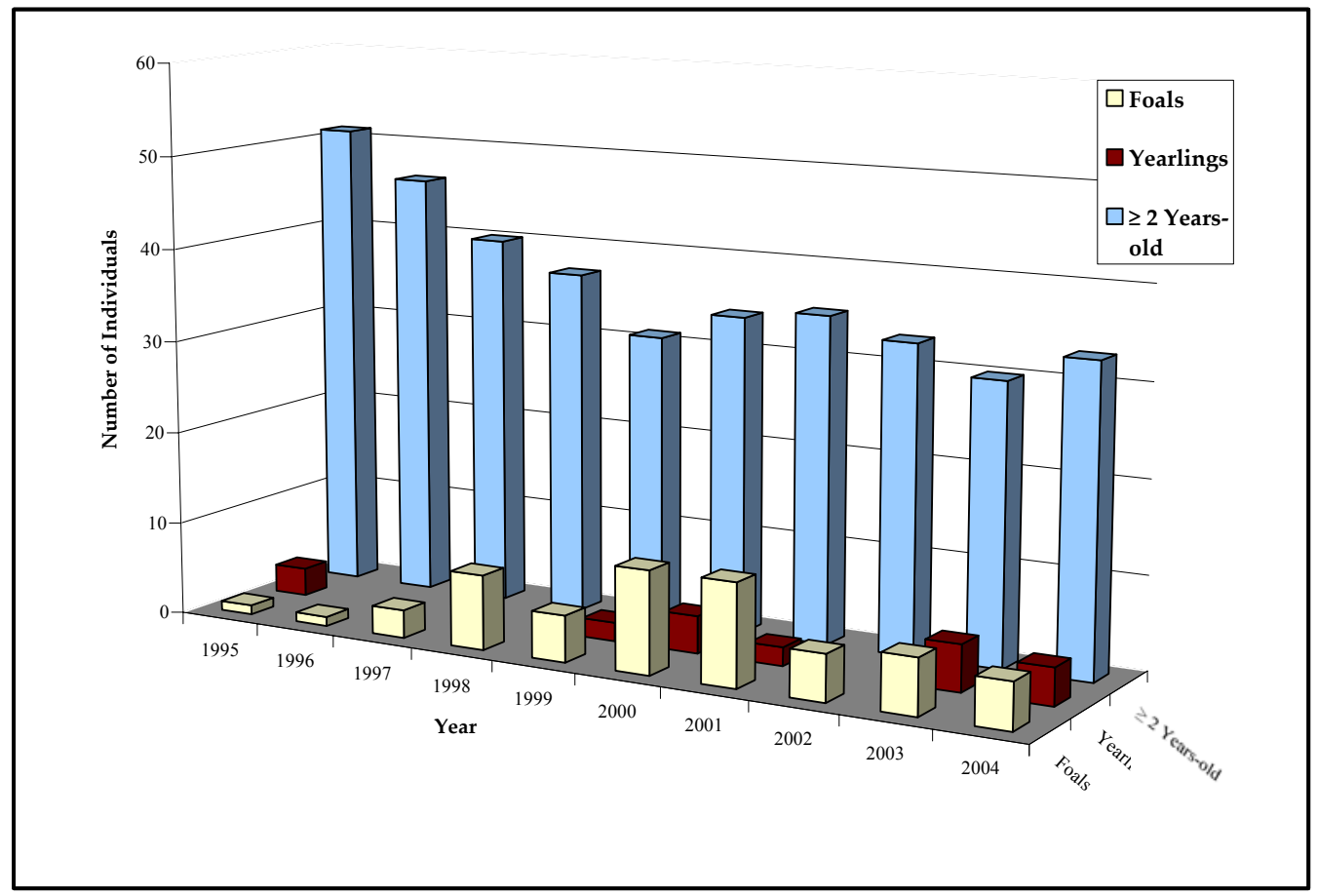

Figure 5-7. Trends in the age structure of the horse population from 1995 to FY/CY 2004.

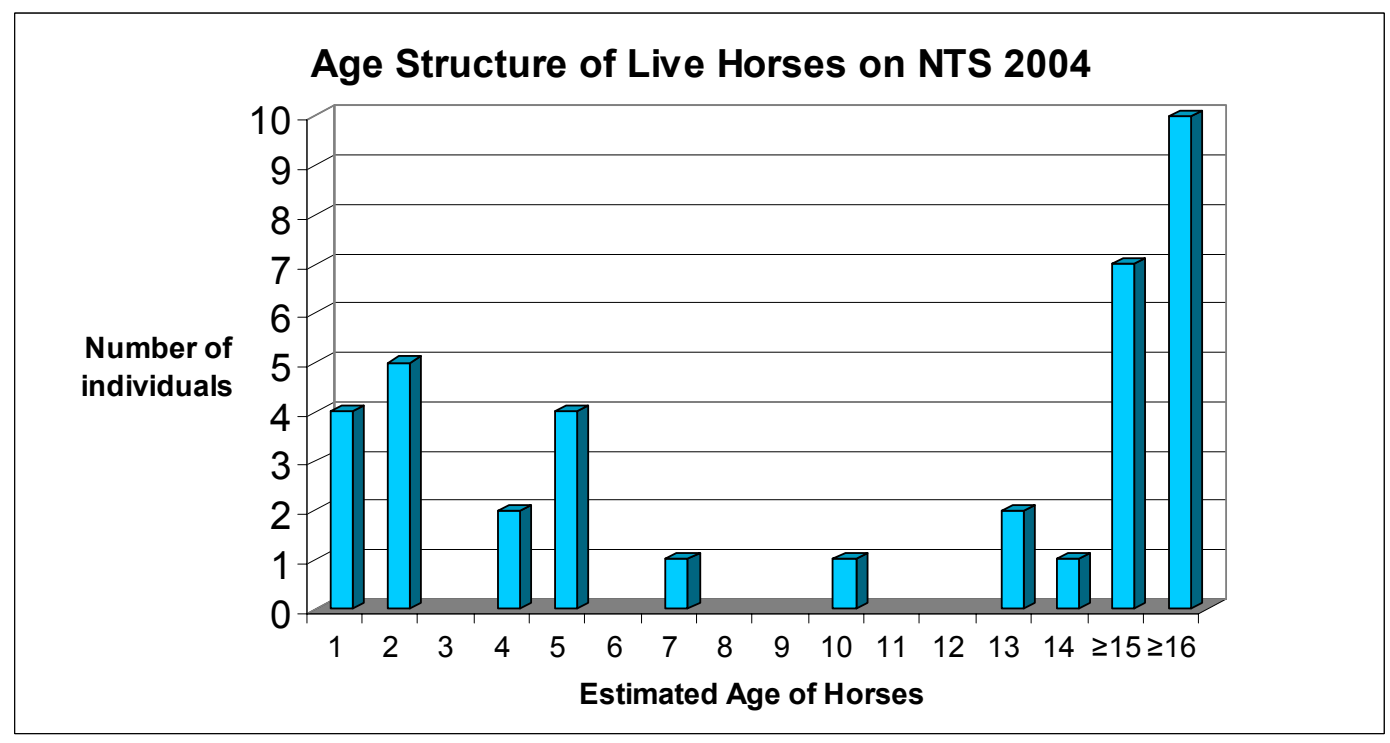

Figure 5-8. Estimated age structure of live horses on the NTS. 


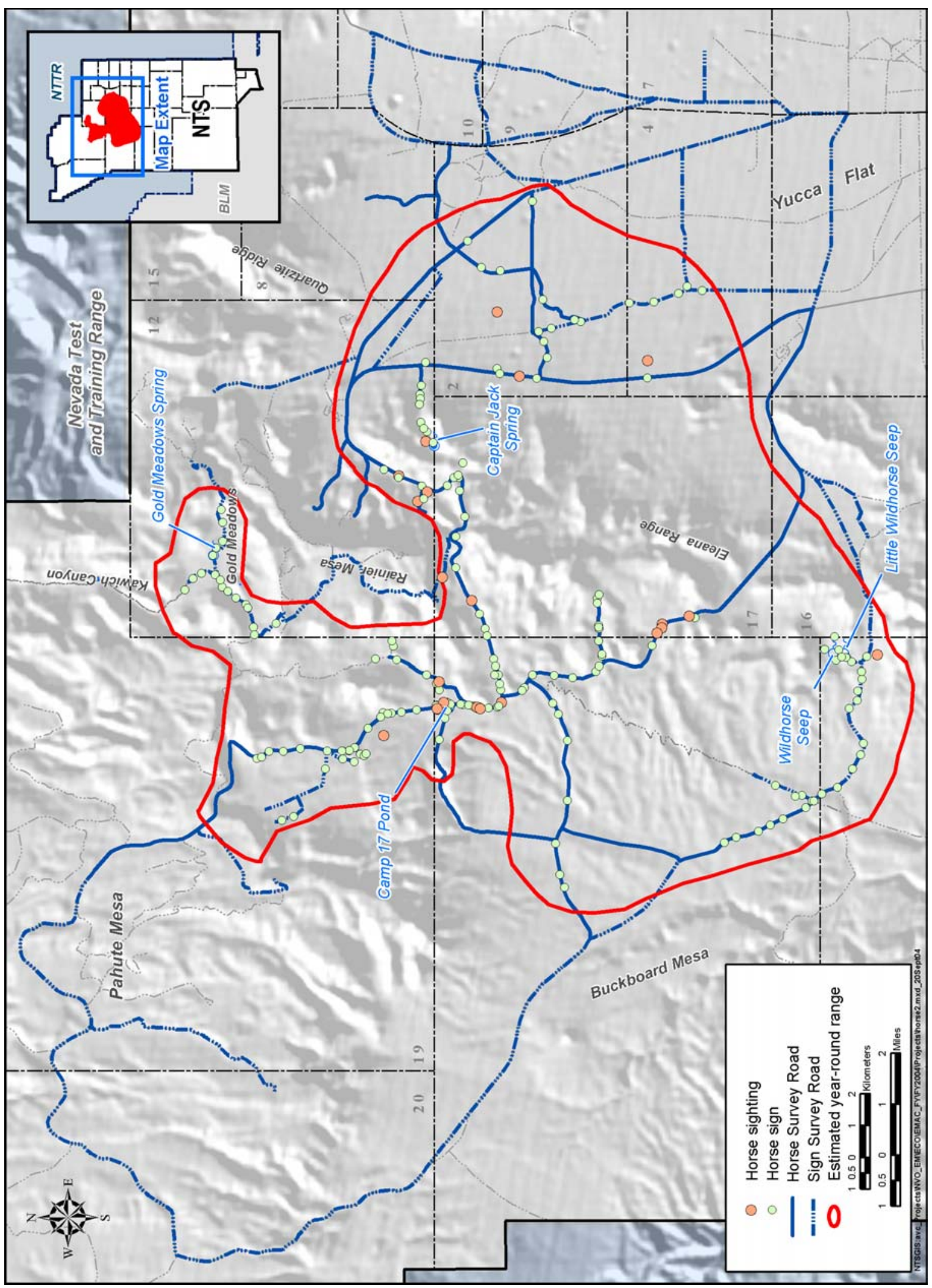

Figure 5-9. Feral horse sightings and horse sign observed on the NTS during FY/CY 2004. 


\subsubsection{Horse Use of NTS Water Sources}

The NTS horse population is dependent on several natural and human-made water sources in Areas 18, 12, and 30 (Figure 5-9) during different seasons. Human-made water source availability has not changed greatly over the last eight years. Wildhorse and Little Wildhorse seeps, both located in Area 30, are important winter-spring water sources. Two other natural water sources (Captain Jack Spring in Area 12, Gold Meadows Spring in Area 12) and one human-made pond (Camp 17 Pond in Area 18) were used by horses this summer, as in past years. Overall, Captain Jack Spring and Camp 17 Pond were the most important summer-fall water sources for horses based on the presence and quantity of horse sign and trampled vegetation. Horses often use ephemeral water sources in winter such as rock tanks and natural pools that collect water from rain and snowmelt. They appear to be much less dependent on human-made sources in winter.

Wildhorse and Little Wildhorse seeps were used by several bands of horses during the spring of 2004 (as in previous years) when water was available. Horse usage declined during early summer as these springs dried up. Gold Meadows sump became dry in September of 2004 as in the previous year. This fact probably restricted horse grazing to areas closer to Camp 17 pond throughout the summer.

As in past years, none of the human-made ponds or the plastic-lined sumps within or on the edge of the annual horse range (see Section 5.3.2, Figure 5-13) was used this year. No horse signs have ever been found at these ponds, suggesting that horses do not drink from them.

\subsubsection{Birds}

\subsubsection{Raptors}

Several raptors occur and breed on the NTS. Some are sensitive species and all are protected/regulated under the Migratory Bird Treaty Act and/or Nevada state law. Raptors include all vultures, hawks, kites, eagles, ospreys, falcons, and owls. Because these birds occupy high trophic levels of the food chain, they are regarded as indicators of ecosystem stability and health. Including the western burrowing owl, there are nine raptors which are known to breed on the NTS (Greger and Romney, 1994).

In FY/CY 2004, no surveys to locate new raptor nests were conducted, however opportunistic sightings were recorded throughout the year. In addition, no active raptor nests were found during surveys of buildings scheduled for demolition (see Section 2.0). The recorded raptor mortality on the NTS from 1990-2003 totaled only 34 Individuals (see FY 2003 EMAC Report). No raptor mortality was detected on the NTS during FY/CY2004. Overall impacts to raptor populations from NNSA/NSO activities at NTS are very low.

Opportunistic sightings of raptors were common this year and included Red-tailed hawks, Turkey Vultures, Golden Eagles, American Kestrels and Prairie Falcons. Many of these individuals are commonly seen perching on utility poles on Frenchman and Yucca Flat. A Peregrine Falcon (Accipiter peregrinus) previously listed at threatened, was observed perched on a utility pole near the Mercury highway on Northwest area of Frenchman Flat on June 2, 2004. This bird appeared to be a juvenile that was dispersing from habitat off the NTS. They do not breed on the NTS and are uncommon on the NTS. During late March of 2004, a Bald Eagle (Haliaeetus leucocephalus) was observed perched in a cable yard near Rainier Mesa Road in Area 2. The Bald eagle is currently listed as a federally threatened species. Other species of raptors such as Cooper's Hawks (Accipter cooperii) and Great Horned Owls (Bubo virginianus) have been observed during Fall migration (September) around water sources (see 
Wetlands Section 5.3.1) adjacent to Rainier Mesa. Raptor breeding will be periodically monitored at least once every five years.

\subsubsection{Bird Mortality}

Bird mortality is recorded as a measure of potential impacts that NNSA/NSO activities may have on protected bird species (Table 5-8). Nineteen bird mortalities were recorded in FY/CY 2004. Two of the primary causes of bird mortality were road kill and electrocution. In one particular case, the electrocution of both Common Raven adults occurred at the nest site as a result of their wings coming in contact with power lines, after which their four young ravens starved to death. On September 22, 2004, an adult, female Red-tailed Hawk was hit by a car and injured on Frenchman Flat. Biologists transported the bird to the North Las Vegas animal hospital for examination and treatment. It was later released in the Las Vegas area. In early October, an adult female Golden Eagle was grounded in Frenchman Flat. It was captured and taken to the North Las Vegas animal hospital for examination. It appeared to be weak from lack of food. It was tested for West Nile Virus and the test came back negative. It was cared for by Wild Wings and later released near Corn Creek on the Desert National Wildlife Range.

\subsection{Wetlands and Wildlife Water Sources}

Natural wetlands (e.g., vegetated seeps and springs) and human-made water sources (e.g., sumps and sewage lagoons) on the NTS provide unique habitats for vegetation and wildlife. In prior years, natural wetlands on the NTS were evaluated for their potential to qualify as "jurisdictional wetlands" under the Clean Water Act (CWA). The presence of three wetland field indicators (vegetation, hydrology, and

Table 5-8. Records of bird mortality on the NTS in FY/CY 2004.

\begin{tabular}{|c|c|c|c|c|c|c|}
\hline \multirow[b]{2}{*}{ Species } & \multicolumn{6}{|c|}{ Cause of Death } \\
\hline & Electrocution & $\begin{array}{c}\text { Road } \\
\text { kill }\end{array}$ & Predation & $\begin{array}{c}\text { Nest } \\
\text { Mortality }\end{array}$ & Unknown & Other $^{1}$ \\
\hline $\begin{array}{l}\text { American Coot } \\
\text { (Fulica americana) }\end{array}$ & & & & & 1 & \\
\hline $\begin{array}{l}\text { Chukar } \\
\text { (Alectorus chukar) }\end{array}$ & & 2 & & & & 2 \\
\hline $\begin{array}{r}\text { Common Raven } \\
\text { (Corvus corax) }\end{array}$ & 2 & & & 4 & & \\
\hline $\begin{array}{l}\text { Common Poorwill } \\
\text { (Phalaenoptilus nuttallii) }\end{array}$ & & 2 & & & & \\
\hline $\begin{array}{l}\text { Gambel's Quail } \\
\text { (Callipepla gambelii) }\end{array}$ & & 2 & & & & \\
\hline $\begin{array}{l}\text { Horned Lark } \\
\text { (Eremophila alpestris) }\end{array}$ & & 1 & & & & \\
\hline $\begin{array}{l}\text { Loggerhead Shrike } \\
\text { (Lanius Iudovicianus) }\end{array}$ & & 1 & & & & \\
\hline $\begin{array}{l}\text { Mourning Dove } \\
\text { (Zenaida macroura) }\end{array}$ & & & 2 & & & \\
\hline Total & 2 & 8 & 2 & 4 & 1 & 2 \\
\hline
\end{tabular}

${ }^{1}$ Found dead in oil pan 
soils) were the basis for determining whether individual wetlands might be considered jurisdictional wetlands (i.e., wetlands over which the U.S. Army Corps of Engineers [USACE] takes legal jurisdiction for the purposes of permitting, mitigation, and rehabilitation for site alterations).

Inherent in the concept of jurisdictional wetlands was the assumption that these isolated wetlands were important for interstate commerce such as hunting, recreation, or for other related uses as defined by the CWA. Constructed sumps and sewage lagoons were specifically exempted from jurisdiction by the CWA. In FY 2001 there was a basic shift in interpretation of the laws and policies determining jurisdiction over such natural wetlands. The catalyst for this change in interpretation was the Supreme Court ruling concerning jurisdiction over isolated waters of the U.S. as authorized by the CWA (Solid Waste Agency of Northern Cook County vs. U.S. Army Corps of Engineers (USACE), No. 99-1178, January 9, 2001 ["SWANCC"]). The essence of this ruling was that isolated wetlands (i.e., wetlands not contiguous with adjacent rivers or water systems used for interstate commerce) that were not used for recreation (e.g., hunting or bird watching) and were not located on American Indian lands were no longer considered to be under the control of the USACE, thus eliminating the need for more stringent permitting (Section 404 Permit) prior to proposed habitat alterations and subsequent habitat rehabilitation after alterations.

In FY/CY 2004 a formal request was initiated by BN through NNSA/NSO to the USACE to confirm that there are no jurisdictional wetlands on the NTS under the current interpretation of the SWANCC ruling. While the SWANCC ruling will most likely alter the potential of NTS wetlands from being considered jurisdictional, the ruling will not alter the basic underlying principle of protecting wetlands as unique and important habitats for wildlife. Characterization of these important mesic habitats and periodic monitoring of their hydrologic and biotic parameters were started in FY 1997 as components of EMAC and will continue in the future. This monitoring will help identify annual fluctuations and ranges in measured parameters to help determine if these fluctuations and ranges are natural or are related to NNSA/NSO activities.

\subsubsection{Constructed Wetlands Monitoring}

Surveys were conducted in FY/CY 2004 on human-made wetlands located on Frenchman Lake (an area previously considered under the jurisdictional control of the USACE because of it's being considered "Waters of the U.S.") to describe and characterize the wetlands. These surveys were consistent with the underlying goal of protecting NTS wetlands as unique habitats. Twelve wetlands were identified and characterized. They had not been previously described in the wetland assessment of 1997 (Hansen, et al. 1997). Each of these wetlands was created by excavation of soil from the playa on Frenchman Lake that seasonally fills with water during storm-runoff and becomes vegetated by trees and other plants. These depressions were associated with the construction of nuclear test facilities such as instrumentation sheds that were partially buried for added protection, for control of surface water flow, or for other activities

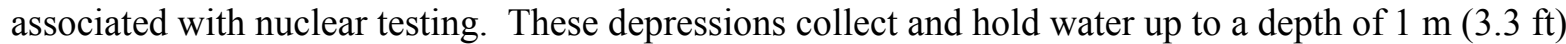
through the spring and into summer providing a relatively reliable source of water for vegetation and wildlife. Figure 5-10 shows the general location of these twelve wetlands on Frenchman Lake. Table 5-9 shows the area of these wetlands.

During FY/CY 2004 descriptive data for these wetlands, including many digital photographs, were collected and entered into the EGIS. It is anticipated that an updated technical supplement report will be prepared during CY 2005 or CY 2006 to describe these and other wetlands that were not included in the initial Nevada Test Site Wetlands Assessment (Hansen et al., 1997). 


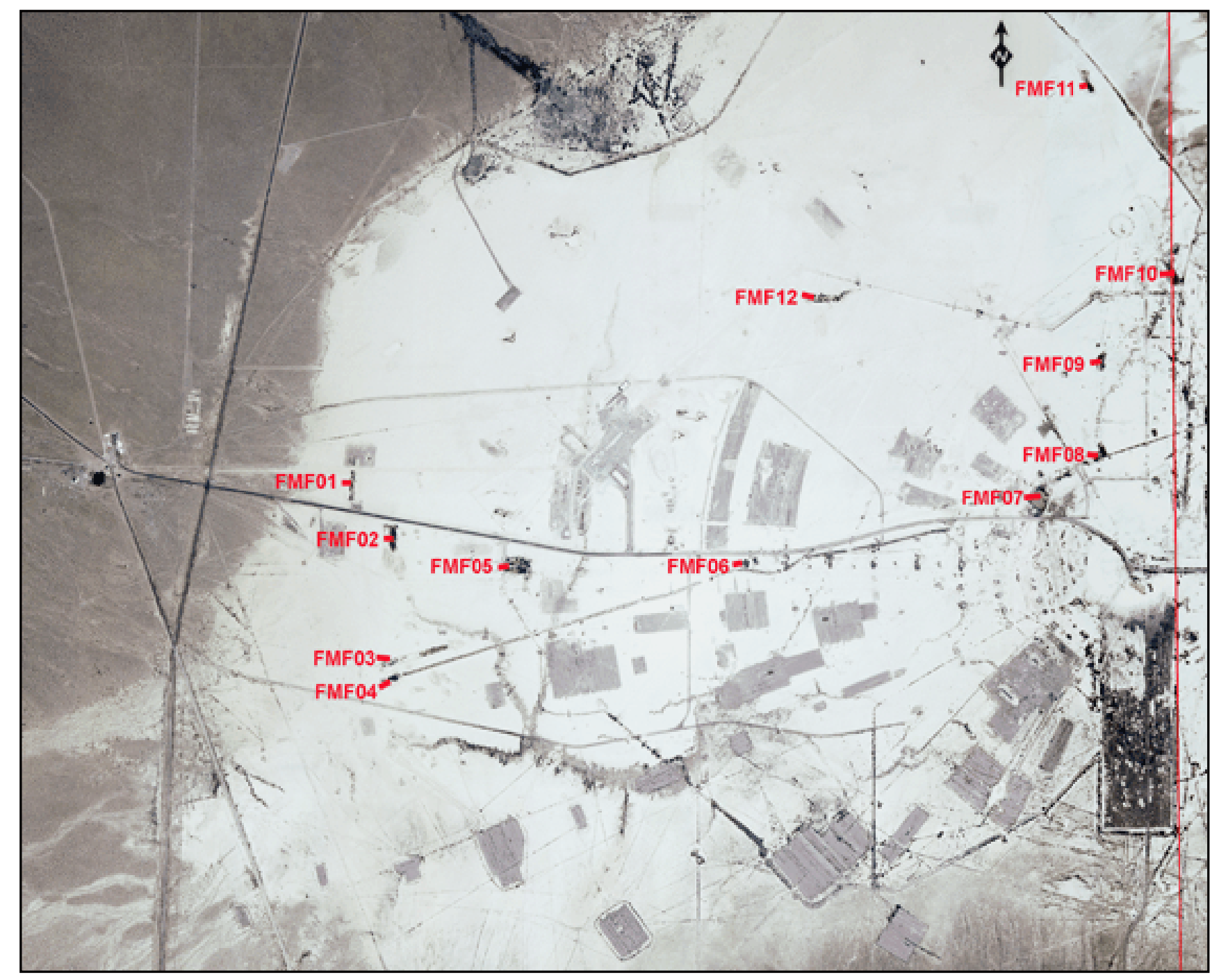

Figure 5-10. Location of constructed wetlands surveyed in FY/CY 2004 on Frenchman Lake (Source: DOE, 2002b). 
Table 5-9. Description of constructed wetlands on Frenchman Lake characterized in FY/CY 2004.

\begin{tabular}{|c|c|c|c|c|c|}
\hline $\begin{array}{l}\text { Wetland } \\
\text { ID Number }\end{array}$ & $\begin{array}{c}\text { UTM Coordinates } \\
\text { Easting }\end{array}$ & $\begin{array}{c}\text { NAD27, Zone } 11 \\
\text { Northing }\end{array}$ & $\begin{array}{c}\text { Dimensions of Water Ponds and Wetlands* } \\
\text { length } X \text { width in meters }\end{array}$ & $\begin{array}{l}\text { Approximate } \\
\text { Surface Area } \\
\text { of Water }\left(\mathrm{m}^{2}\right) \\
\end{array}$ & $\begin{array}{c}\text { Approximate } \\
\text { Total Area } \\
\text { of Wetland }{ }^{*}\left(\mathrm{~m}^{2}\right) \\
\end{array}$ \\
\hline FMF02 & 592965 & 4072880 & $4 \mathrm{~m} \times 60 \mathrm{~m}$ Water; $16 \mathrm{~m} \times 73 \mathrm{~m}$ Total & 240 & 1,168 \\
\hline FMF03 & 593109 & 4072492 & $8 \mathrm{~m} \times 120 \mathrm{~m}$ Water; $20 \mathrm{~m} \times 254 \mathrm{~m}$ Total & 960 & 5,080 \\
\hline FMF05 & 593393 & 4072782 & $(18 \mathrm{~m} \times 57)+(8 \mathrm{~m} \times 50)$ Water; $57 \mathrm{~m} \times 60 \mathrm{~m}$ Total & 1,426 & 3,420 \\
\hline FMF06 & 594194 & 4072795 & $14 \mathrm{~m} \times 14$ Water; $24 \mathrm{~m} \times 28 \mathrm{~m}$ Total & 196 & 672 \\
\hline FMF07 & 595216 & 4053012 & 48 m X 72 m Water; 60 m X 92 m Total & 3,456 & 5,520 \\
\hline FMF10 & 595672 & 4073813 & $13 \mathrm{~m} \times 56 \mathrm{~m}$ Water; $15 \mathrm{~m} \times 91 \mathrm{~m}$ Total & 728 & 1,365 \\
\hline FMF11 & 595392 & 4074438 & 15 m X 86 m Water; 22 m X 111 m Total & 1,290 & 2,442 \\
\hline \multirow[t]{2}{*}{ FMF12 } & 594466 & 4073702 & $7 \mathrm{~m} \times 125 \mathrm{~m}$ Water; $15 \mathrm{~m} \times 165 \mathrm{~m}$ Total & 875 & 2,475 \\
\hline & & & $\begin{array}{r}\text { Total Square Meters: } \\
\text { (Total Hectares:) } \\
\text { (Total Acres:) }\end{array}$ & $\begin{array}{c}9,939 \\
(0.99 \mathrm{ha}) \\
(2.46 \mathrm{ac})\end{array}$ & $\begin{array}{c}\mathbf{2 3 , 8 0 7} \\
(2.38 \mathrm{ha}) \\
(5.88 \mathrm{ac})\end{array}$ \\
\hline
\end{tabular}

\footnotetext{
*Total area of the wetland was the water pond area and the area occupied by the vegetation adjacent to the pond.
} 
An example of one of the twelve wetlands on Frenchman Lake is shown in Figure 5-11. The most characteristic plant species growing along the edges of these wetland depressions is saltcedar (Tamarix rammosissima).

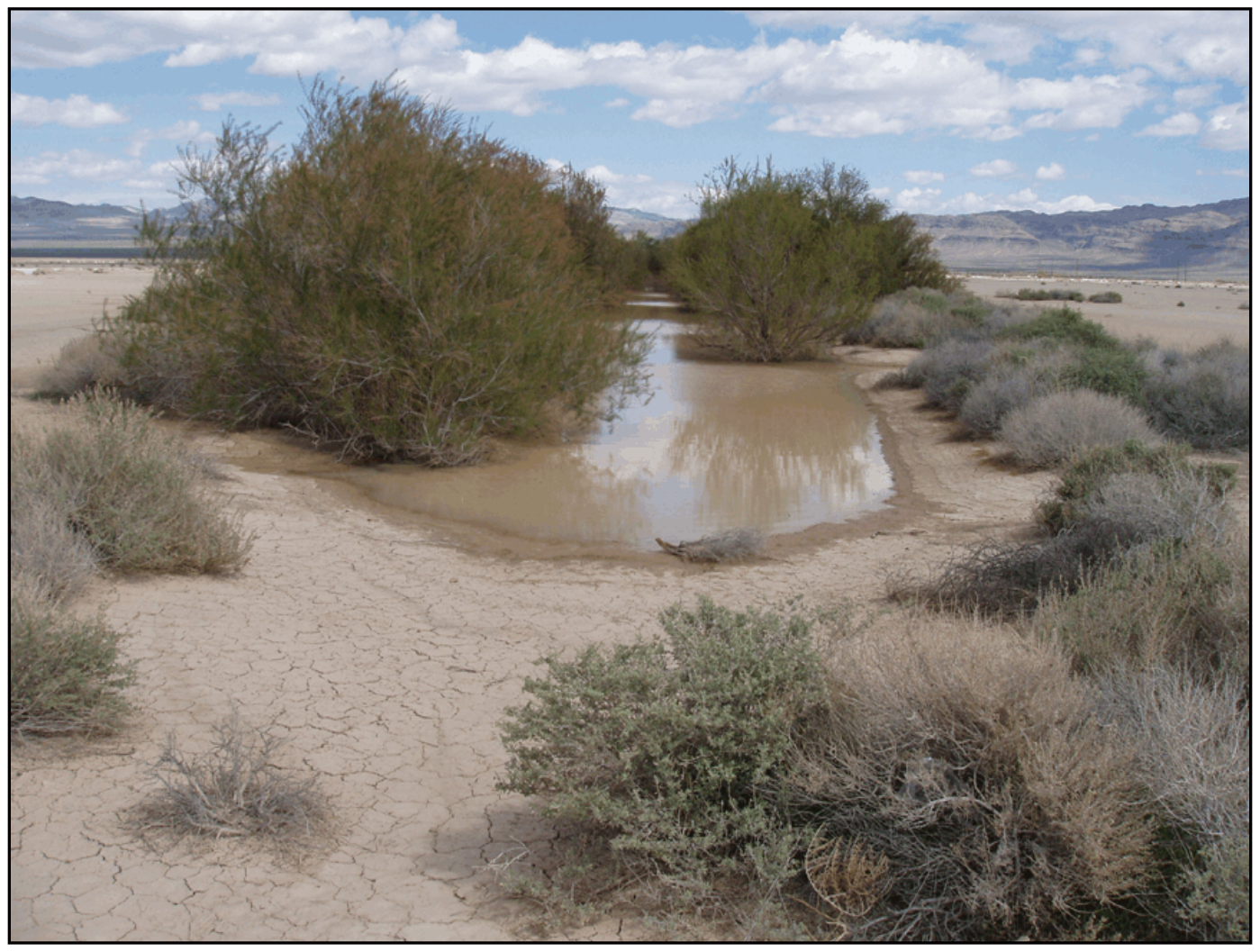

Figure 5-11. An example of one of the newly surveyed wetlands on Frenchman Lake. (Photo by D. J. Hansen, April 7, 2004).

\subsubsection{Natural Wetlands Monitoring}

Monitoring of numerous wetlands continued this fiscal year to characterize seasonal baselines and trends in physical and biological parameters. Eighteen known wetlands were visited at least once during the year to record the presence/absence of land disturbance, water flow rates, and surface area of standing water (Table 5-10, Figure 5-12). Sizes of wetlands monitored varied greatly from very small areas $\left(<1 \mathrm{~m}^{2}\right)$ to moderately sized springs and playa ponds $\left(>3,000 \mathrm{~m}^{2}\right)$. Surface flow rates were low $(<3 \mathrm{~L} / \mathrm{min})$ at most wetlands where flow was measurable.

Wildlife use data collected at all water sources are summarized in Table 5-11. Overall, more than 40 species of birds and more than 940 individual birds were detected during FY/CY 2004. Moderate rainfall, particularly in February, March, and April of 2004 favored increases in bird populations. It was common to observe large numbers of young of the year, Gambel's Quail, Chukar, and Mourning Doves, throughout the NTS and at springs. The higher number of species counted is a result of visiting more sites ( 31 sites compared to 14) than in the previous year and also from improvements in observation techniques. Improved techniques employed in FY/CY 2004 include: increased observation time, repeated visits to a site, and the use a constructed guzzler coupled with an observation blind. 
Table 5-10 Hydrology data from natural water sources on the NTS collected during FY/CY 2004.

\begin{tabular}{|c|c|c|c|c|}
\hline Water Source & Date & $\begin{array}{c}\text { Surface } \\
\text { Area of } \\
\text { Water } \\
\left(\mathrm{m}^{2}\right)^{\mathrm{a}}\end{array}$ & $\begin{array}{c}\text { Surface } \\
\text { Flow } \\
\text { Rate } \\
\text { (L/min) }\end{array}$ & Disturbance at Spring \\
\hline Cane Spring & $7 / 20 / 2004$ & 15 & 1.0 & None \\
\hline Captain Jack Spring & 9/1/2004 & 13 & 0.8 & Horse grazing and trampling \\
\hline Cottonwood Spring & $4 / 14 / 2004$ & 9 & $\mathrm{NM}^{\mathrm{C}}$ & None \\
\hline Coyote Spring & $3 / 31 / 2004$ & $<1$ & 0.0 & None \\
\hline Gold Meadows Spring & $6 / 16 / 2004$ & 250 & $N A^{d}$ & Horse grazing and trampling \\
\hline Gold Meadows Spring & $9 / 15 / 2004$ & 0 & NA & Horse grazing and trampling \\
\hline Little Wildhorse Seep & $4 / 1 / 2004$ & 5 & NM & Horse grazing and trampling \\
\hline Pavits Spring & $3 / 31 / 2004$ & 1 & NM & None \\
\hline Rainier Spring & 9/7/2004 & 0 & 0.0 & None \\
\hline Reitmann Seep & $5 / 25 / 2004$ & $<1$ & 0.0 & None \\
\hline Tippipah Spring & $8 / 18 / 2004$ & 120 & NM & None \\
\hline Tongue Wash Tank & $6 / 30 / 2004$ & 0 & 0.0 & None \\
\hline Topopah Spring & $6 / 1 / 2004$ & $<1$ & NM & None \\
\hline Tupappa Seep & $3 / 31 / 2004$ & $<1$ & 0.0 & None \\
\hline Twin Springs & $4 / 14 / 2004$ & 2 & NM & None \\
\hline Wahmonie Seep No.1 & $4 / 15 / 2004$ & $<1$ & 0.0 & None \\
\hline Whiterock Spring & $7 / 27 / 2004$ & 6 & 2.3 & None \\
\hline Wildhorse Seep & $4 / 1 / 2004$ & 66 & 1.0 & Horse grazing and trampling \\
\hline Yellowrock Springs & $4 / 14 / 2004$ & $<1$ & NM & None \\
\hline Yucca Playa Pond & $8 / 24 / 2004$ & 1,200 & NA & None \\
\hline $\begin{array}{l}{ }^{a} m^{2}=\text { Square meter } \\
{ }^{b} \text { L/min }=\text { Liters per min } \\
{ }^{c} N M=\text { Not measurab } \\
{ }^{{ }^{c}} \text { NA }=\text { Not Applicable }\end{array}$ & ue to diffusec & flow & & \\
\hline
\end{tabular}




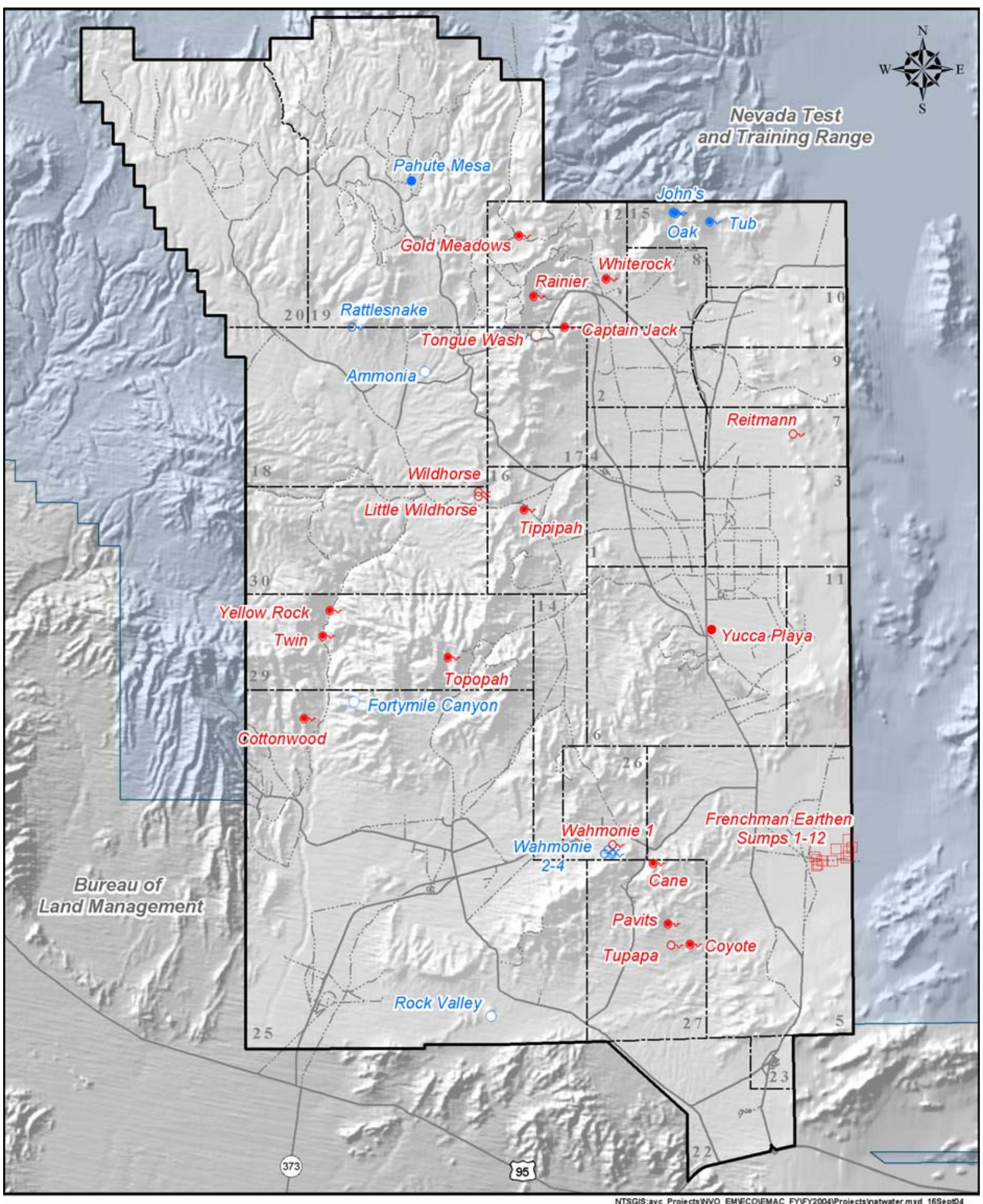

Natural Water Source Types
$\square$ Earthen Sump
Or Seep
Tank
— Primary Road
---NTS Operational Areas
- Pond
or Spring
- - - Secondary Road NTS Boundary
( RED indicates wetlands that were sampled.)

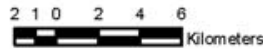
\begin{tabular}{rrrrrr}
2 & 1 & 0 & 2 & 4 & 6 \\
\hline & & & &
\end{tabular}

Figure 5-12. Natural water sources on the NTS sampled during FY/CY 2004. 
Table 5-11. Wildlife observed at selected NTS natural water sources during FY/CY 2004.

\begin{tabular}{|c|c|c|c|c|c|c|c|c|c|c|c|c|c|c|c|c|c|c|}
\hline Wildlife Observed & 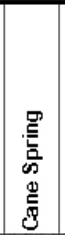 & 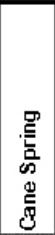 & 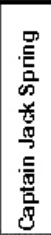 & 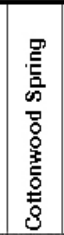 & 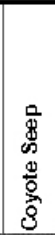 & $\begin{array}{l}5 \\
\dot{0} \\
\mathbf{2} \\
\frac{1}{9} \\
\frac{5}{5} \\
\frac{5}{4} \\
\frac{5}{4}\end{array}$ & 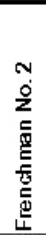 & 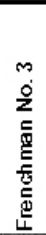 & 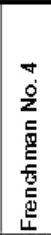 & 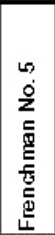 & 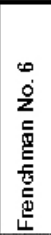 & 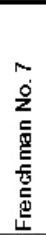 & 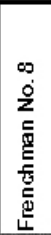 & 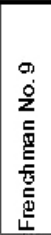 & 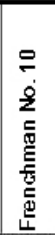 & 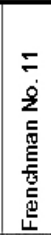 & 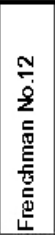 & 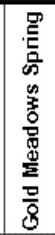 \\
\hline FY 2004 Date Sampled: & $7 / 1$ & $7 / 20$ & $9 / 1$ & $4 / 14$ & $3 / 31$ & $4 / 7$ & $4 / 7$ & $4 / 7$ & $4 / 7$ & $\overline{4 / 7}$ & $4 / 7$ & $4 \overline{7}$ & $\overline{4 / 7}$ & $4 / 7$ & $4 / 7$ & $4 \overline{7}$ & $4 / 7$ & $6 / 16$ \\
\hline \multicolumn{19}{|c|}{ 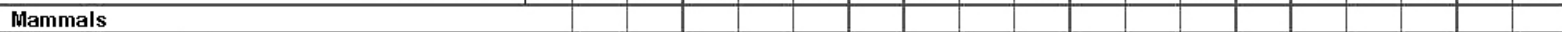 } \\
\hline \multicolumn{19}{|l|}{ Bobcat (Lynx rufus) } \\
\hline Coyote (Canus latrans) & 1 & $\mathrm{P}$ & & & $\mathrm{P}$ & $\mathrm{P}$ & $\mathrm{P}$ & $\mathrm{P}$ & $P$ & $\mathrm{P}$ & $\mathrm{P}$ & & $\mathrm{P}$ & $P$ & & $\mathrm{P}$ & $\mathrm{P}$ & 2 \\
\hline Cottontail rabbit (Syivilagus audubonii) & 1 & 2 & & & & & & & & & & & & & & & & \\
\hline Feral horse (Equus caballus) & & & $\mathrm{P}$ & & & & & & & & & & & & & & & $\mathrm{P}$ \\
\hline Mule deer (Odocoileus hemionus) & $\mathrm{P}$ & $\mathrm{P}$ & $\mathrm{P}$ & & & & $\mathrm{P}$ & & & $\mathrm{P}$ & $\mathrm{P}$ & & & $\mathrm{P}$ & & $\mathrm{P}$ & & $\mathrm{P}$ \\
\hline Pronghom Antelope (Antilocapra americana) & & & & & & & & & & $\mathrm{P}$ & $\mathrm{P}$ & & & $\mathrm{P}$ & & $\mathrm{P}$ & $\mathrm{P}$ & \\
\hline \multicolumn{19}{|l|}{ Birds } \\
\hline \multicolumn{19}{|l|}{ Black-chinned Hummingbird (Archilochus alexandri) } \\
\hline Black-headed Grosbeak (Pheucticus melanocephalus) & & & & & & & & & & & & & & & & & & 1 \\
\hline Black Phoebe (Sayomis nigrescens) & & & & & & 1 & & 1 & & & & 1 & & & & & & \\
\hline Black-throated Grey Warbler (Dendroica nigrescens) & & & & & & & & & & & & & & & & & & 1 \\
\hline Black-throated Sparrow (Amphispiza bilineata) & 5 & & & 2 & 2 & & & & & & & & & & & & & \\
\hline \multicolumn{19}{|l|}{ Blue-winged Teal (Anas discors) } \\
\hline Brewer's Sparrow (Spizella breweri) & & 10 & & & & & & & & & & & & & & & & 20 \\
\hline Brown-headed Cowbird (Molothrus ater) & & & & & & & & & & & & & & & & & & 2 \\
\hline Chipping Sparrow (Spizella passerina) & & & & & & & & & & & & & & & & & & 20 \\
\hline Chukar (Alectoris chukar) & & & 12 & & & & & & & & & & & & & & & \\
\hline Cinnamon Teal (Anas cyanoptera) & & & & & & & & 3 & & & & 7 & & & & 2 & 2 & \\
\hline Common Raven (Corvus corax) & & & & & & & & & & & & & & & & & & 1 \\
\hline Common Snipe (Gallinago gallinago) & & & & & & & & & 1 & 1 & & & & & & & & \\
\hline Cooper's Hawk (Accipiter cooperi) & & & 1 & & & & & & & & & & & & & & & \\
\hline Gambel's Quail (Callipepia gambelii) & $>200$ & $>40$ & & & & & & & & & & & & & & & & \\
\hline \multicolumn{19}{|l|}{ Great Homed Owl (Bubo virginianus) } \\
\hline Homed Lark (Eremophila alpestris) & & & & & & 3 & & & & & & & & & 1 & & & \\
\hline House Finch (Garpodacus mexicana) & & & & 2 & & & & & & & & & & & & & & 20 \\
\hline \multicolumn{19}{|l|}{ Killdeer (Charadrius vociferus) } \\
\hline \multicolumn{19}{|l|}{ Lazuli Bunting (Passerna amoena) } \\
\hline \multicolumn{19}{|l|}{ Loggehead Shrike (Lanius ludovicianus) } \\
\hline Lesser Goldfinch (Carduelis psaltria) & & & & & & & & & & & & & & & & & & 1 \\
\hline Mouming Dove (Zenaida macroura) & 10 & 1 & & $>10$ & & & & 1 & 1 & & & & & & 1 & & & 10 \\
\hline Mountain Bluebird (Sialia currucoides) & & & & & & & & & & & & & & & & & & 1 \\
\hline Northem Flicker (Colaptes auratus) & & & & & & & & & & & & 1 & 1 & & & & & 1 \\
\hline Northem Mockingbird (Mimus polyglottos) & & & & & & & & & & & & & & & & & & 2 \\
\hline \multicolumn{19}{|l|}{ Pinion Jay (Gymnominus cyanocephalus) } \\
\hline \multicolumn{19}{|l|}{ Roadrunner (Geococcyx califomianus) } \\
\hline Rock Wren (Salpinctes obsoletus) & & & & 1 & & & & & & & & & & & & & & \\
\hline Say's Phoebe (Saya sayornis) & & & & & & 2 & & & & & & & & & 1 & & & \\
\hline \multicolumn{19}{|l|}{ Scrub Jay (Aphelocoma coerulescens) } \\
\hline Spotted Towhee (Pipilo enthropthalmus) & & & 4 & & & & & & & & & & & & & & & \\
\hline Turkey Vulture (Gathartes aura) & & & & & & & & & & & & & & & & & & 5 \\
\hline Violet-green Swallow (Tachycineta thallassina) & & & & & & & & & & & & & & & & & & 1 \\
\hline Westem Bluebird (Sialia mexicana) & & & & & & & & & & & & & & & & & & 1 \\
\hline \multicolumn{19}{|l|}{ Westem Sandpiper (Calidis maun') } \\
\hline Westem Tanager (Piranga ludovidana) & & & & & & & & & & & & & & & & & & \\
\hline Westem Kingbird (Tyrannus verticalus) & & & & & & & & & & & & & & & & & & \\
\hline White-crowned Sparow (Zonotrichis leucophrys) & & & & 1 & & & & & 2 & & & 2 & & & & & & \\
\hline Wilson's Warbler (Wilsonia pusilla) & & & & & & & & & & & & & & & & & & \\
\hline Unidentified Hummingbird & & & & & & & & & & & & & & & & & & \\
\hline Numbers of Bird Species detected & 3 & 3 & 3 & 5 & 1 & 3 & 0 & 3 & 3 & 1 & 0 & 4 & 1 & 0 & 3 & 1 & 1 & 15 \\
\hline $\mathrm{P}=$ Species presence inferred from sign & & & & & & & & & & & & & & & & & & \\
\hline
\end{tabular}


Table 5-11 (Continued).

\begin{tabular}{|c|c|c|c|c|c|c|c|c|c|c|c|c|c|c|c|}
\hline Wildlife Observed & 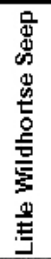 & 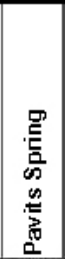 & 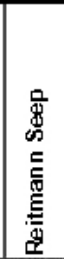 & 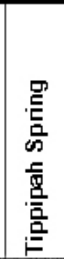 & 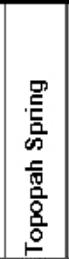 & 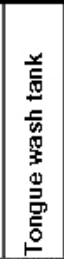 & 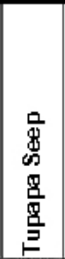 & 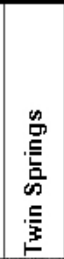 & 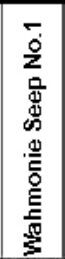 & 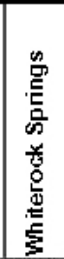 & 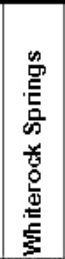 & 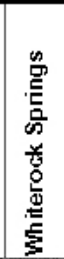 & 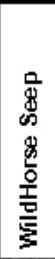 & 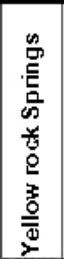 & 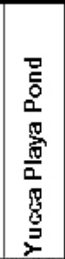 \\
\hline FY 2004 Date Sampled: & $\overline{4 / 1}$ & $3 \sqrt{31}$ & $5 \sqrt{25}$ & $8 / 18$ & $6 / 1$ & $6 \sqrt{30}$ & $3 / 31$ & $4 / 14$ & $4 / 15$ & $5 \sqrt{26}$ & $7 \pi 27$ & $8 / 24$ & $4 / 1$ & $4 / 14$ & $8 / 24$ \\
\hline \multicolumn{16}{|c|}{ - } \\
\hline Bobcat (Lynx rufus) & & & & & & & & & $\mathrm{P}$ & & & & & & \\
\hline Coyote (Canus latrans) & & $\mathrm{P}$ & $\mathrm{P}$ & $\mathrm{P}$ & $\mathrm{P}$ & $\mathrm{P}$ & & & $\mathrm{P}$ & $\mathrm{P}$ & $\mathrm{P}$ & & & $\mathrm{P}$ & $\mathrm{P}$ \\
\hline Cottontail rabbit (Syivilagus audubonii) & & & & 1 & & & & & & & & & & & \\
\hline Feral horse (Equus caballus) & $\mathrm{P}$ & & & & & & & & $\mathrm{P}$ & & & & $\mathrm{P}$ & & \\
\hline Mule deer (Odocoileus hemionus) & & & & $\mathrm{P}$ & $\mathrm{P}$ & & & $\mathrm{P}$ & $\mathrm{P}$ & $\mathrm{P}$ & & & $\mathrm{P}$ & & \\
\hline \multicolumn{16}{|l|}{ Pronghom Antelope (Antilocapra americana) } \\
\hline \multicolumn{16}{|l|}{ Birds } \\
\hline Black-chinned Hummingbird (Archilochus alexandi) & & & & & & & & 1 & & & & & & & \\
\hline \multicolumn{16}{|l|}{ Black-headed Grosbeak (Pheucticus melanocephalus) } \\
\hline \multicolumn{16}{|l|}{ Black Phoebe (Sayomis nigrescens) } \\
\hline \multicolumn{16}{|l|}{ Black-throated Grey Warbler (Dendroica nigrescens) } \\
\hline Black-throated Sparrow (Amphispiza bilineata) & 1 & 3 & & & & & & 2 & & & & 3 & & 2 & \\
\hline Bluewinged Teal (Anas discors) & & & & & & & & & & & & & & & 4 \\
\hline Brewer's Sparrow (Spizella breweri) & & & & & & & & & & & & 6 & & & \\
\hline Brown-headed Cowbird (Molothrus ater) & & & & & & & & & & 6 & & & & & \\
\hline \multicolumn{16}{|l|}{ Chipping Sparrow (Spizella passerina) } \\
\hline Chukar (Alectons chukar) & & & & 20 & 10 & & & & & & & & & & \\
\hline \multicolumn{16}{|l|}{ Cinnamon Teal (Anas cyanoptera) } \\
\hline Common Raven (Corvus corax) & & & & & 1 & & & & & & & 1 & & & \\
\hline \multicolumn{16}{|l|}{ Common Snipe (Gallinago gallinago) } \\
\hline \multicolumn{16}{|l|}{ Cooper's Hawk (Accipiter cooperi) } \\
\hline Gambel's Quail (Callipepla gambelii) & & & & 60 & & & & & & & $>20$ & & & 1 & \\
\hline Great Homed Owl (Bubo virginianus) & & & & & & & & & & & 3 & 1 & & & \\
\hline \multicolumn{16}{|l|}{ Homed Lark (Eremophila alpestris) } \\
\hline House Finch (Carpodacus mexicana) & & & & & 4 & & 3 & & & 8 & & 10 & & 2 & \\
\hline Killdeer (Charadrius vociferus) & & & & & & & & & & & & & 1 & & \\
\hline Lazuli Bunting (Passerina amoena) & & & & & & & & & & 1 & & & & & \\
\hline Loggehead Shrike (Lanius ludovicanus) & & & & & & & & & & & & & & & 1 \\
\hline Lesser Goldfinch (Carduelis psaltria) & & & & & 15 & & & & & & & 5 & & & \\
\hline Mouming Dove (Zenaida macroura) & & & 3 & 10 & $>100$ & 3 & & & & $>150$ & $>50$ & 6 & & 3 & 3 \\
\hline \multicolumn{16}{|l|}{ Mountain Bluebind (Sialia currucoides) } \\
\hline \multicolumn{16}{|l|}{ Northem Flicker (Colaptes auratus) } \\
\hline Northem Mockingbird (Mmus polyglottos) & & & & & & & & & & & & & & 2 & \\
\hline \multicolumn{16}{|l|}{ Pinion Jay (Gymnominus cyanocephalus) } \\
\hline Roadrunner (Geococcyx califomianus) & 1 & & & & & & & & & & & & & & \\
\hline Rock Wren (Salpinctes obsoletus) & & & & & & & & & & & & & & 2 & \\
\hline Say's Phoebe (Saya sayornis) & & & 1 & & & & & & & & & & & 2 & \\
\hline Scrub Jay (Aphelocoma coerulescens) & & & & & & 2 & & & & & & & 1 & & 1 \\
\hline Spotted Towhee (Pipilo enthropthaimus) & & & & & 4 & & & & & & & & & & \\
\hline \multicolumn{16}{|l|}{ Turkey Vulture (Cathartes aura) } \\
\hline Violet-green Swallow (Tachycineta thallassina) & & & & & & & & & & & & & & & \\
\hline Westem Bluebird (Sialia mexicana) & & & & & & & & & & & & & & & \\
\hline Westem Sandpiper (Calidis mauri) & & & & & & & & & & & & & & & 13 \\
\hline Westem Tanager (Piranga ludovidana) & & & & & & & & & & 3 & & 1 & & & \\
\hline Westem Kingbird (Tyrannus verticalus) & & & & 1 & & & & & & & & & & & \\
\hline White-crowned Sparrow (Zonotrichis leucophrys) & & & & & & & & & & & & & & & \\
\hline Wilson's Warbler (Wilsonia pusilla) & & & & & & & & & & 2 & & & & & \\
\hline Unidentified Hummingbird & & & & & & & & & & 1 & & & & & \\
\hline Numbers of Bird Species detected & 2 & 1 & 2 & 4 & 6 & 2 & 1 & 2 & 0 & 7 & 3 & 8 & 2 & 7 & 5 \\
\hline P = Species presence inferred from sign & & & & & & & & & & & & & & & \\
\hline
\end{tabular}




\subsubsection{Constructed Water Source Monitoring}

BN biologists conducted quarterly monitoring of constructed water sources. These sources, located throughout the NTS (Figure 5-13), include 39 plastic-lined sumps, 7 sewage treatment ponds, 8 unlined well ponds, and one radioactive containment pond. Several ponds or sumps are located next to each other at the same project site. Many animals rely on these human-made structures as sources of free water. Wildlife and migratory birds may drown in steep-sided or plastic-lined sumps as a result of entrapment, or ingest contaminants in drill-fluid sumps or evaporative ponds. Ponds are monitored to assess their use by wildlife and to develop and implement mitigation measures to prevent them from causing significant harm to wildlife.

Constructed water sources were visited during four quarterly sampling periods: December 2003, March, June, and September 2004. Sewage ponds and well reservoirs were visited once annually in September. At each site, a BN biologist recorded the presence or absence of standing water and the presence of animals or their sign around the water source. The presence of dirt ramps or plastic ladders, which allow animals to escape if they fall in, have also been installed at many plastic-lined sumps, and the presence, absence, and condition of these structures were also noted. All dead animals (or any remains of an animal) in or adjacent to a human-made water source are recorded.

During FY/CY 2004, use of plastic-lined sumps was limited to doves, and passerine birds (e.g., cravens, horned larks, house finches). Mourning Doves were particularly high in number at many water sources during spring-summer. There were no reports of dove mortalities at any earthen ponds in FY/CY 2004. Birds were observed much less at the plastic-lined sumps compared to the unlined ponds. Migratory bird use at earthen ponds in September included use by ducks, including Cinnamon Teal, Blue-winged Teal, American Coots and shorebirds such as Great Egrets, Wilson's Phalaropes, Killdeer, and Western Sandpipers, etc. In addition, uncommon opportunistic sightings of two Phainopeplas (Phainopepla nitens) were recorded at Well 5A in Frenchman Flat in late May of 2004 (see Table 5-10). Few dead animals were recorded in any plastic-lined sumps during FY/CY 2004. Mortalities were limited to small mammals (kangaroo rats) in Area 6 Sump and to one unidentified remains of a mid-sized mammal (deer or coyote) detected in a U20 Post Shot \#1 pond in Area 20. It was recommended that an animal dirt ramp be constructed in this pond to prevent future entrapments of game species. Dirt ramps, where installed, have been very effective in allowing animals to exit sumps without becoming entrapped.

\subsubsection{West Nile Virus Surveillance}

West Nile Virus (WNV) is a potentially serious illness that is spread to humans and other animals through mosquito bites. It was first discovered in Uganda in 1937 and was not detected in North America until 1999. In southern Nevada, it was not detected until the spring of 2004. In order to determine if mosquitoes on the NTS carried WNV, several sites were sampled for mosquitoes. BN biologists worked with Clark County Health District personnel to learn the proper sampling protocol. On August 31, four sites were sampled: Camp 17 Pond (Area 18), Yucca Lake Sewage Lagoons (Area 6), J-11 Pond (Area 25), and Mercury Sewage Lagoons (Area 23). Only three mosquitoes were captured and these were captured at Yucca Lake Sewage Lagoons. These were identified by Clark County Health District specialist, Richard Hicks, as Culex tarsalis which is a known carrier of WNV. The specimens tested negative for WNV. On September 14, three sites were sampled: Camp 17 Pond, Well C1 Pond (Area 6), and Well 5B Pond (Area 5). Mosquitoes were captured at each site and were submitted to Richard Hicks for identification and testing.

Results of mosquito identification are as follows: 14 individuals of Culiseta inernata collected at Camp 17 Pond, 2 individuals of Culex tarsalis collected at Well C1, and 37 individuals of Culex tarsalis collected at Well 5B. None of these tested positive for WNV. On September 20, three sites were 


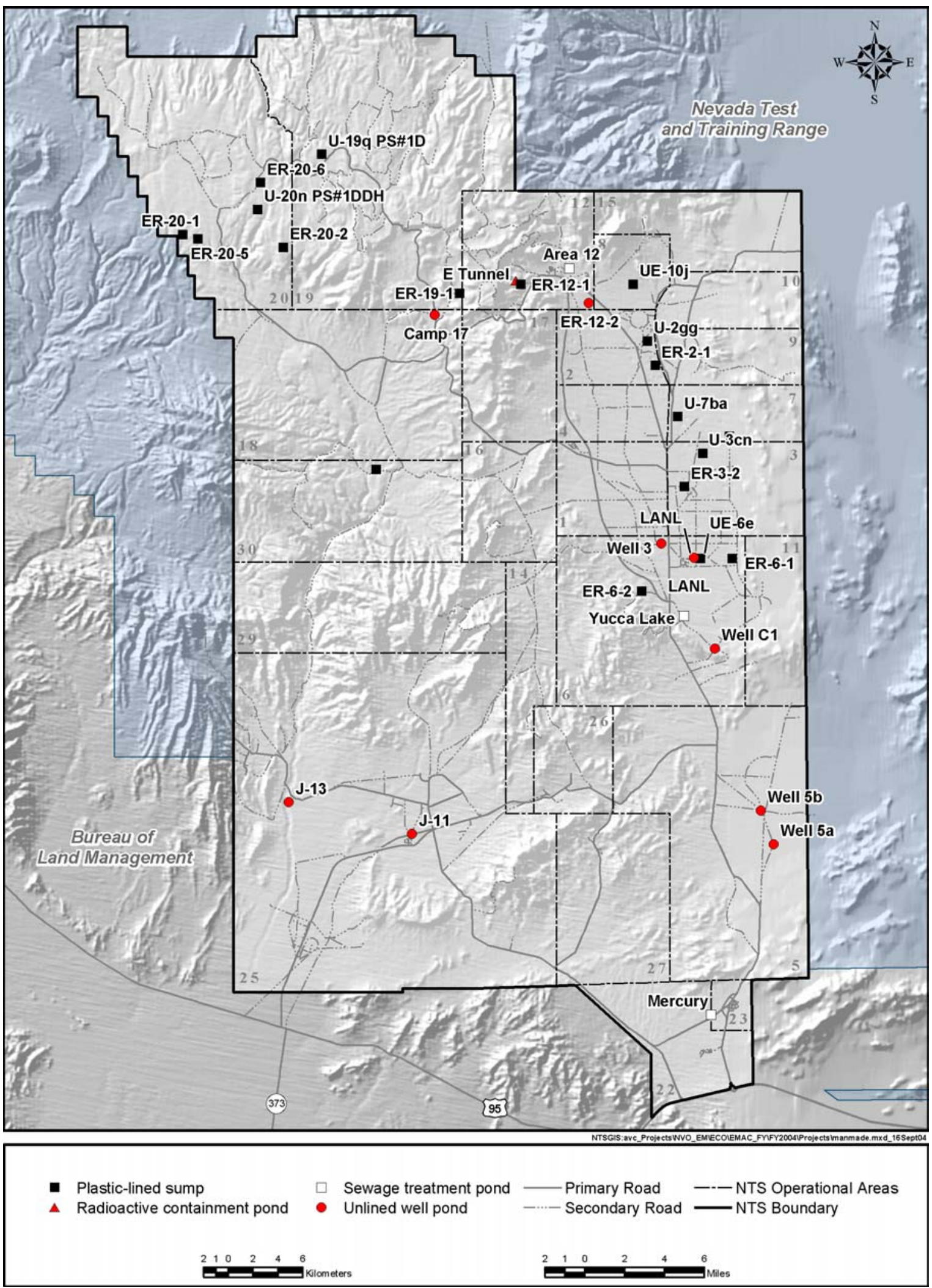

Figure 5-13. Constructed water sources monitored for wildlife use and mortality on the NTS during FY/CY 2004. 
sampled: Cane Spring (Area 5), J-11 Pond, and a wet area near Building 23 in Mercury. No mosquitoes were captured due to strong winds. Mosquito species identified will be entered into the EGIS faunal database to define mosquito distribution on the NTS. Sampling will continue next spring and summer to determine if mosquitoes on the NTS have WNV. 


\subsection{HABITAT RESTORATION MONITORING}

Over the past several decades, some efforts have been made to revegetate disturbed areas on the NTS with native plants (Hunter, et al., 1980; Hunter, et al., 1987; Romney et al., 1989; Wallace and Romney, 1977; 1980; Wallace et al., 1977; 1980). These efforts have been driven by the need to develop viable reclamation techniques in the Mojave Desert which could then be applied to NTS project sites where soil stabilization or habitat reclamation is needed. NNSA/NSO evaluates revegetation as a potential mitigation measure for disturbance to soils on a site-specific basis based on site size, future use, nature of soils, annual precipitation, slope, aspect, and site location (DOE, 1996). To date, the majority of projects for which revegetation has been pursued and funded are abandoned industrial or nuclear test support sites that have been characterized and remediated under the Environmental Restoration (ER) Program. Also, the ER Program has funded revegetation for some soil cover caps to protect against soil erosion and water percolation to buried waste. In the fall of 2002 a burned area resulting from a wildland fire in Area 12 was revegetated as a measure to reduce the potential for soil erosion following the fire.

A goal of EMAC is to monitor the long-term outcome of both natural vegetation succession and succession by revegetation at disturbed sites throughout the NTS. As opportunities arise, periodic monitoring is conducted to help develop a site-wide habitat restoration plan and better evaluate criteria which influence revegetation success. This year, EMAC supported monitoring a wildland fire burn site and historical revegetation test plots.

\subsection{Egg Point Fire Burn Site}

A wildfire of unknown origin burned approximately 121 ha $(300 \mathrm{ac})$ in Area 12 on August 16, 2002. The fire, named Egg Point, encompassed vegetation within the blackbrush-Nevada jointfir, singleleaf pinyonblack sagebrush, and rubber rabbitbrush-Nevada jointfir plant communities (Ostler et al., 2000). The majority of plant cover was lost but there did not appear to be any significant impacts to wildlife or to any sensitive plant or animal species. The Nevada Test Site Wildland Fire Management Plan (BN, 2002) prescribes the rehabilitation of land after a fire, mainly for the prevention of future wildland fires, and secondarily for erosion control. In the fall of 2002 and spring of 2003, BN Ecological Services completed the revegetation and soil stabilization of the fire site.

Vegetation monitoring of the burn site was conducted in June 2003 and August 2004 to determine if restoration actions were effective in promoting a plant community less prone to future wildland fires and effective in preventing soil erosion. Monitoring focused on seed germination and plant establishment on the steep upper slopes as well as the lower slopes and bottoms. Line-sample transects were randomly located in these areas and plant density of perennial plant species was recorded.

\subsubsection{Plant Density of Seeded Species}

Plant density on the burn site continues to be low. Drought conditions, although not as severe as they have been the past few years, have not favored good seed germination and plant growth. The density of perennial plant species on the upper slopes was only 1.1 plants $/ \mathrm{m}^{2}$ in 2003 (Table 6-1) and increased to 1.88 plants $/ \mathrm{m}^{2}$ this year. Although the density is still relatively low, the plants that germinated in 2003 appear to be surviving. 
Table 6-1. Perennial plant densities on the upper and lower slopes of the Egg Point Fire restoration site.

\begin{tabular}{|c|c|c|c|c|c|}
\hline \multirow[t]{2}{*}{ Seeded Species } & \multirow[t]{2}{*}{ Common Name } & \multicolumn{2}{|c|}{$\begin{array}{c}\text { Upper Slopes } \\
\text { Density (plants } / \mathrm{m}^{2} \text { ) }\end{array}$} & \multicolumn{2}{|c|}{$\begin{array}{c}\text { Lower Slopes } \\
\left.\text { Density (plants } / \mathrm{m}^{2}\right)\end{array}$} \\
\hline & & 2003 & 2004 & 2003 & 2004 \\
\hline \multicolumn{6}{|l|}{ Shrubs } \\
\hline Artemisia nova & Black sagebrush & 0 & 0.26 & \multicolumn{2}{|c|}{ Not In Seed Mix } \\
\hline Atriplex canescens & Fourwing saltbush & \multicolumn{2}{|c|}{ Not In Seed Mix } & 0.06 & 0.06 \\
\hline $\begin{array}{c}\text { Chrysothamnus } \\
\text { viscidiflorus }\end{array}$ & Rabbitbrush & 0 & 0.03 & 0 & 0.02 \\
\hline $\begin{array}{l}\text { Coleogyne } \\
\text { ramosissima }\end{array}$ & Blackbrush & 0.03 & 0.14 & 0.04 & 0.10 \\
\hline Ephedra viridis & Mormon tea & 0 & 0.01 & 0 & 0 \\
\hline Ericameria nauseosa & Rubber rabbitbrush & 0.07 & 0.10 & 0.29 & 0.09 \\
\hline \multicolumn{6}{|l|}{ Grasses } \\
\hline $\begin{array}{l}\text { Achnatherum } \\
\text { hymenoides }\end{array}$ & Indian ricegrass & 0.01 & 0.07 & 0.01 & 0.05 \\
\hline Elymus elymoides & Bottlebrush squirreltail & 0.04 & 0.03 & 0.03 & 0.05 \\
\hline Poa secunda & Sandberg's bluegrass & 0.72 & 0.67 & 0.04 & 0 \\
\hline Pleuraphis jamesii & Galleta grass & \multicolumn{2}{|c|}{ Not In Seed Mix } & 0.05 & 0.07 \\
\hline \multicolumn{6}{|l|}{ Forbs } \\
\hline Linum lewisii & Blue flax & 0.07 & 0.28 & 0.14 & 0.33 \\
\hline $\begin{array}{r}\text { Eschscholzia } \\
\text { californica }\end{array}$ & California poppy & 0.15 & 0 & 0.40 & 0 \\
\hline Penstemon eatonii & Eaton's penstemon & 0 & 0.17 & 0 & 0.01 \\
\hline Penstemon palmeri & Palmer's penstemon & \multicolumn{2}{|c|}{ Not In Seed Mix } & 0 & 0.02 \\
\hline $\begin{array}{l}\text { Sphaeralcea } \\
\text { grossulariifolia }^{a}\end{array}$ & $\begin{array}{c}\text { Gooseberry leaf } \\
\text { globemallow }\end{array}$ & 0 & 0.10 & 0.04 & 0.08 \\
\hline \multicolumn{2}{|c|}{ Total Perennial Species } & 1.10 & 1.88 & 1.12 & 0.87 \\
\hline
\end{tabular}

${ }^{a}$ Not included in upper or lower seed mix 
There was an increase in FY/CY 2004 in the number of shrubs that have established on the upper slopes (Figure 6-1). There were almost five times as many shrubs in 2004 as there were in 2003. Ericameria nauseosa was as abundant this year as last, but the number of Coleogyne ramosissima showed almost a five-fold increase over last year's density estimates. No seedlings of Artemisia nova were found last year on the upper slopes, although this year it is the most abundant species (Figure 6-2). The density of grass species on the upper slopes was about the same as it was last year. Forbs continue to make a significant contribution to the overall plant density, especially Linum lewisii. Seedlings of Penstemon eatonii were also commonly encountered, whereas none was seen last year. Because of the late sampling date this year, only the density of seeded and perennial species was recorded. Many annual species, some of the seeded forbs, such as Eschscholzia californica, and even some of the perennial grasses had already flowered and dried up and thus were not included in the density estimates. Overall, the density of seeded perennial plants on the burn site is good. It appears that plants are establishing, even under marginal growing conditions.

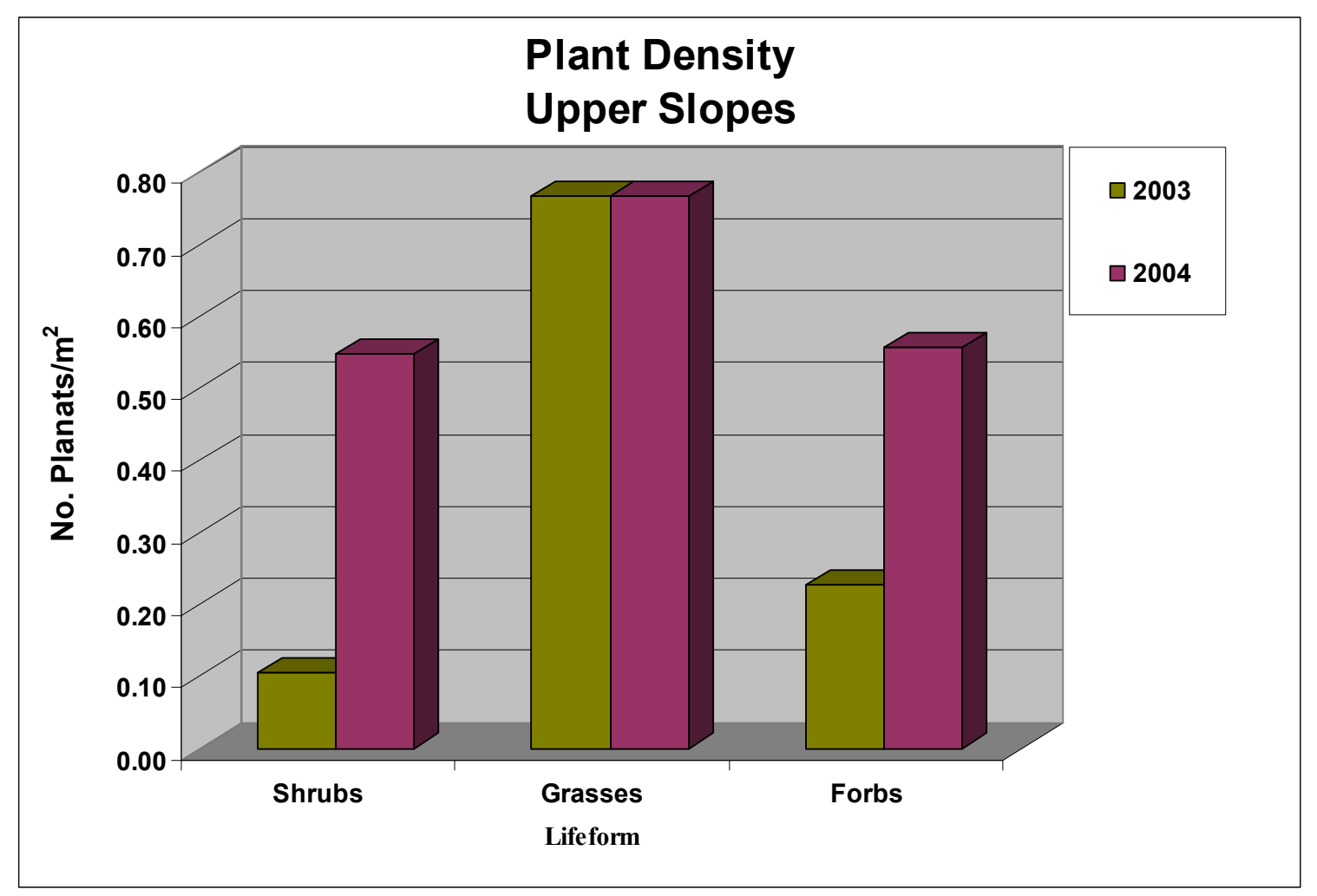

Figure 6-1. Plant density by lifeform and year on the upper slopes of the Egg Point Fire burn site. 


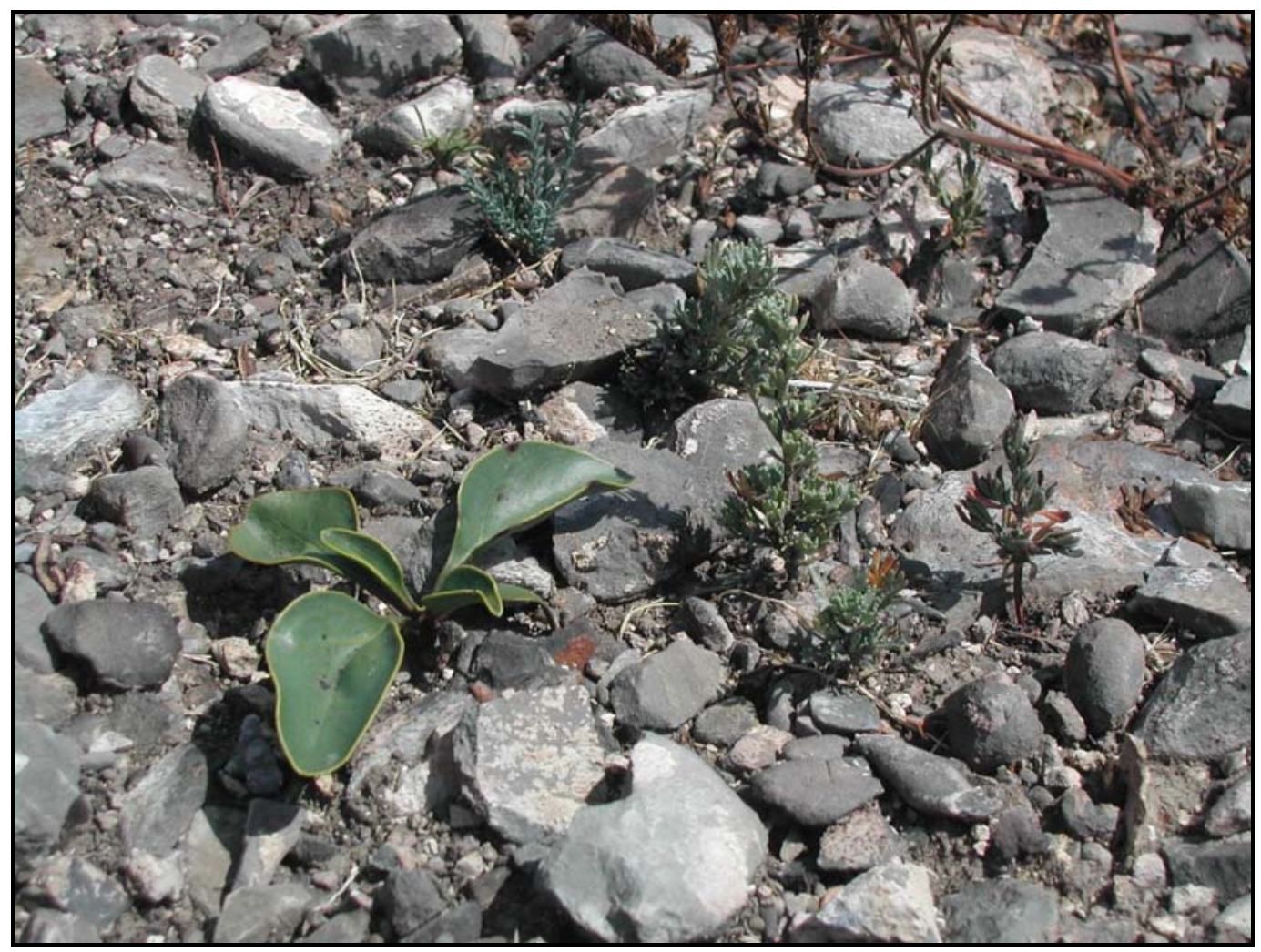

Figure 6-2. Young seedlings of Penstemon eatonii, Artemisia nova, and Coleogyne ramosissima were common on the upper slopes of the burn site. (Photo by D. Anderson, September 15, 2004).

On the lower slopes the density of perennial plant species declined slightly from the 2003 levels (Table 6-1). The most notable decline was that of Ericameria nauseosa, which dropped from 0.29 plants $/ \mathrm{m}^{2}$ in 2003 to only 0.09 plants $/ \mathrm{m}^{2}$ this year. There were about twice as many plants of C. ramosissima this year as there were in 2003. This species was the major component of the plant community prior to the fire and its establishment is encouraging.

The density of grasses was about the same for both years (Figure 6-3). Again, due to the time of monitoring some grasses may not have been noticeable. Acnatherum hymenoides and Elymus elymoides continue to be common on the lower slopes along with Pleuraphis jamesii. The later species, although included in the seed mix, is resprouting from existing plants that were not destroyed during the fire. The decrease in the density of forbs, as explained previously, may be the result of the timing of monitoring.

Several species of invasive annual plants were present on the site. The most obvious species were Salsola tragus, Bromus rubens, and Bromus tectorum. There were a few areas where Halogeton glomeratus was abundant but it was not as common as $S$. tragus or the two bromes. Several native annuals were abundant on the site earlier in the year. The most notable were Argemone munita and Mentzelia montana. No density data was collected for these species or the invasive annuals because of the late sampling date but density data for these species will be collected in future years. 


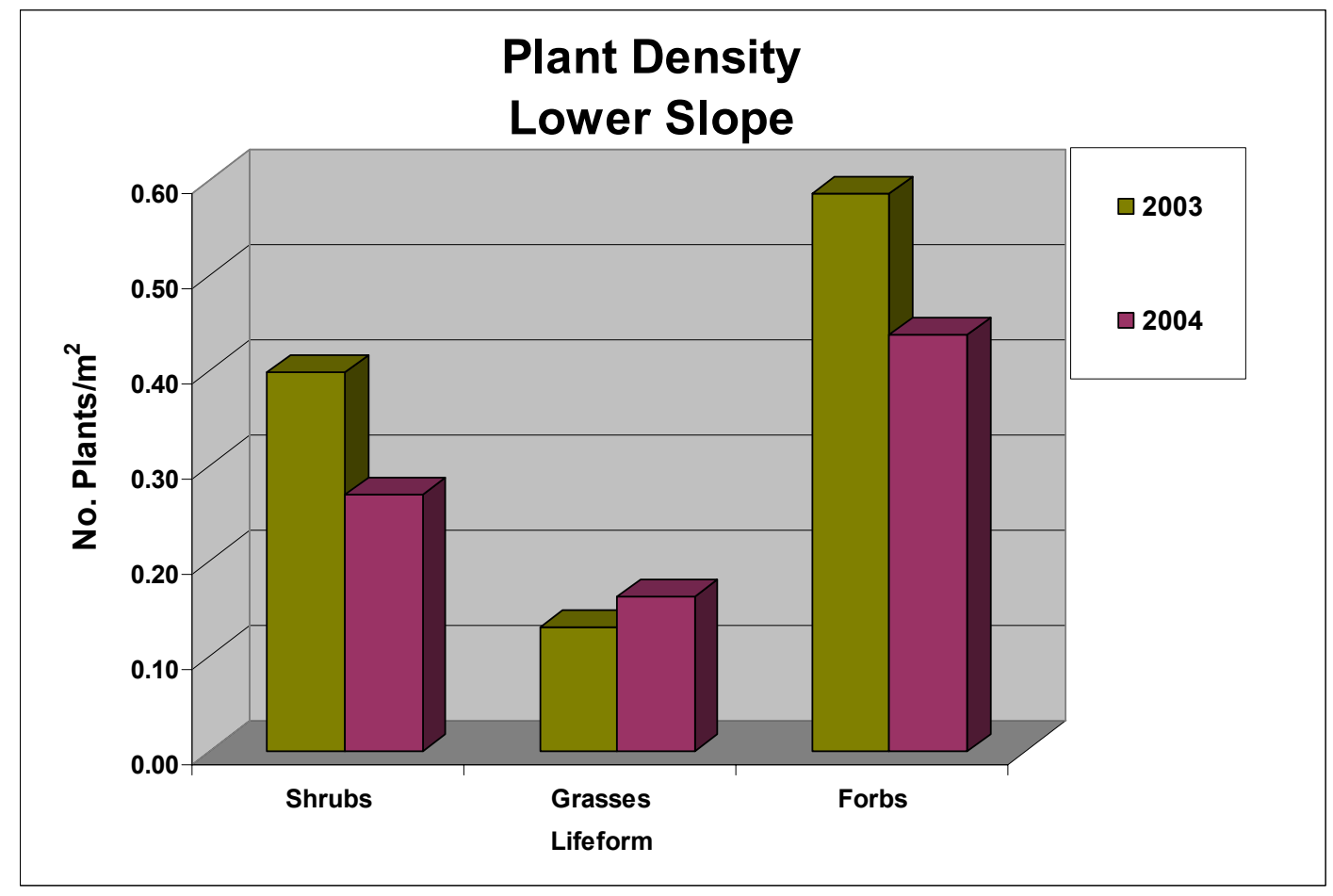

Figure 6-3. Plant density by lifeform and year on the lower slopes of the Egg Point Fire burn site.

\subsubsection{Revegetation Techniques}

Reseeding of Egg Point Fire burn site employed two seeding techniques. The inaccessible upper slopes of the burn site were hand seeded followed by raking (Figure 6-4). The lower slopes were seeded with a mechanical seeder mounted on an all-terrain vehicle that was also equipped with drag chains (Figure 6-5). The hand raking and drag chains were used to roughen the soil surface and at the same time cover the seed. To compare efficacy of the two techniques, an area seeded using the mechanical seeder was sampled, and an area seeded by hand was sampled. Both sites were seeded with the upper slope seed mix within a couple weeks of each other. After the first year density was equally low on both the hand-seeded and mechanically-seeded areas. In 2004 there was a marked difference in seedlings densities. 


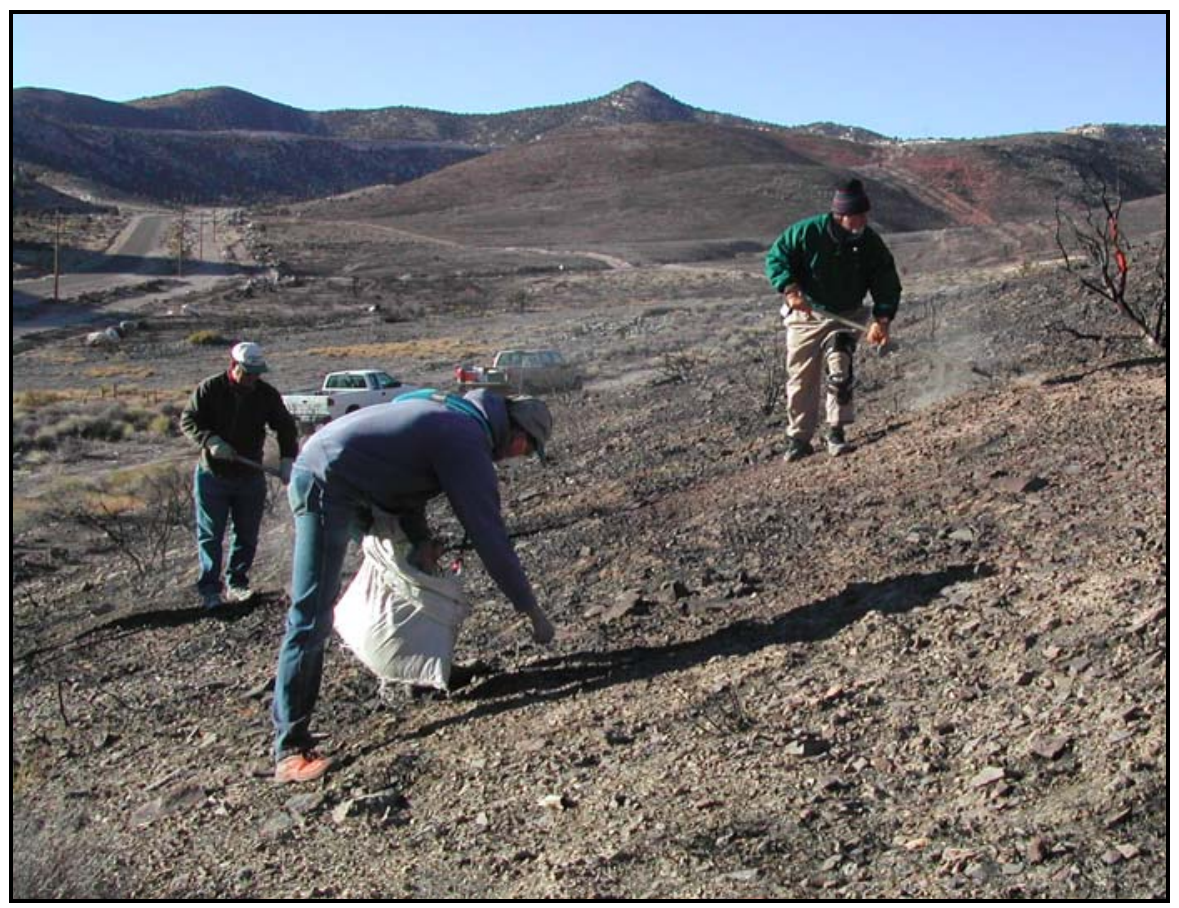

Figure 6-4. Hand seeding and raking in the seed on the upper slopes of the Egg Point Fire burn site.

(Photo by D. Anderson, January 28, 2003).

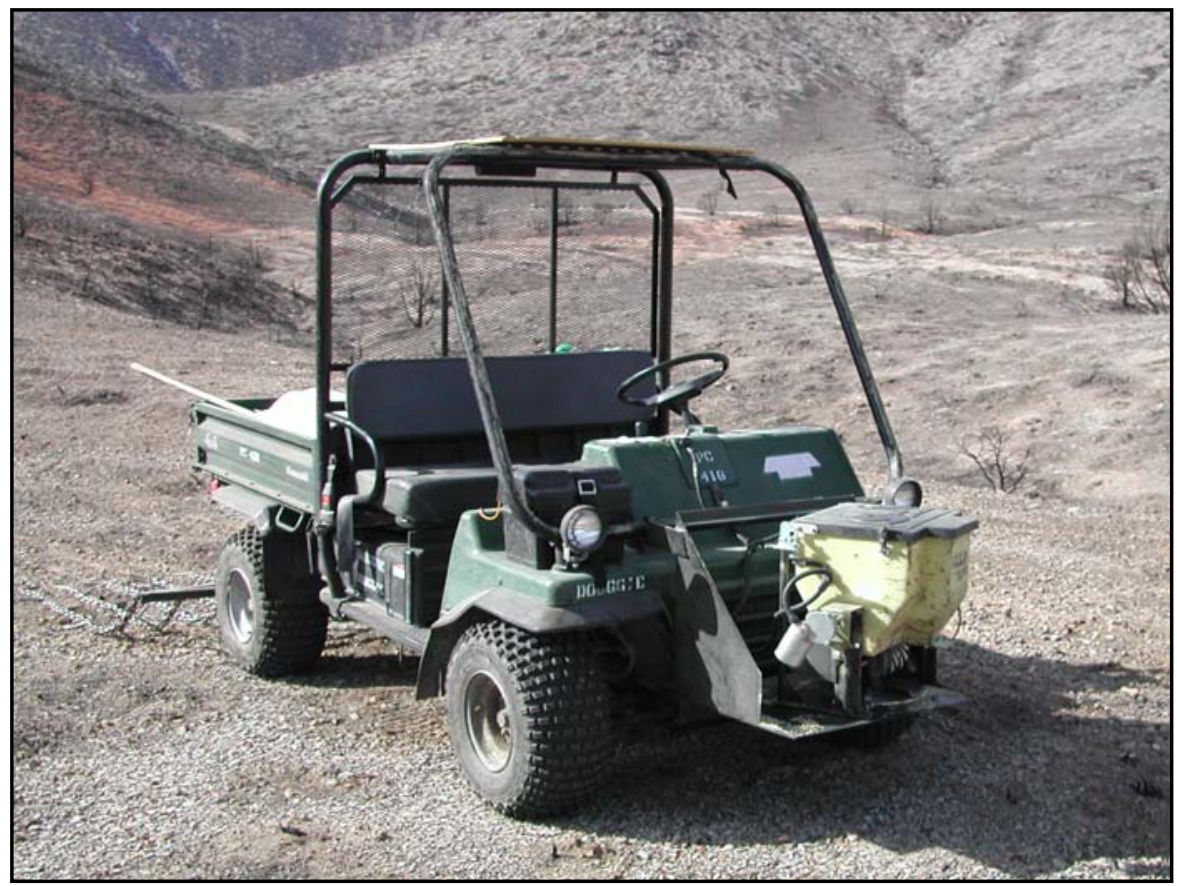

Figure 6-5. An all-terrain vehicle with a mechanical seeder attached to the front and drag chains on the back was used to seed the lower slopes and bottom areas of the Egg Point Fire burn site.

(Photo by D. Anderson, January 28, 2003). 
In 2004 seedling density had increased on both areas, but the increase on areas that were seeded with the mule and drag chains was much greater (Figure 6-6). There were twice as many shrubs on the mechanically seeded site as there were on the hand seeded site. The biggest difference was with Artemisia nova (Table 6-2). In 2003 there was no Artemisia nova in either of the areas. In 2004 there were almost three times as many seedlings on the mechanically-seeded site as there were on the hand-seeded site. No perennial grasses were found on the area that was hand seeded and just like shrubs there were more than twice as many forbs on the mechanically-seeded site as there were on the hand-seeded site. Two commonly occurring forbs, L. lewisii and P. eatonii, were twice as abundant on the mechanically seeded site as they were on the hand seeded site. Overall the density of all perennial plants on the mechanically-seeded site was more than double what it was on the hand-seeded site.

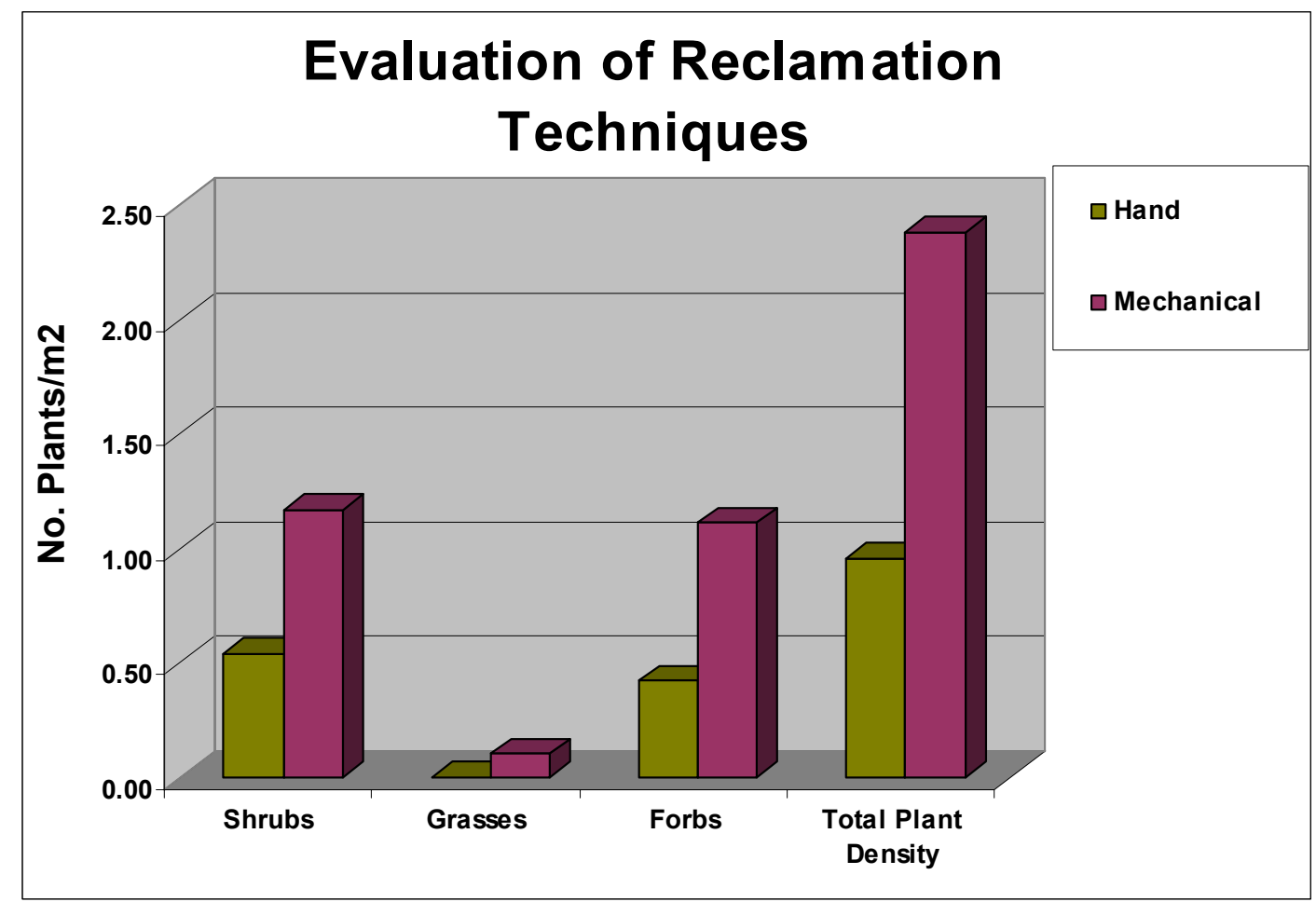

Figure 6-6. Plant densities on hand-seeded versus mechanically seeded sites.

\subsection{Historical Reclamation Research on the NTS}

Over the past several decades, various reclamation research trials have been conducted on the NTS to evaluate different reclamation techniques or to test the performance of certain plant species in this environment. A total of 28 such trial sites were identified from literature and files. The sites were visited and a determination was made as to whether sampling of the site would provide any information on the success of reclamation techniques or plant performance. 
Table 6-2. Perennial plant densities on areas hand-seeded and mechanically-seeded on the Egg Point Fire restoration site.

\begin{tabular}{|c|c|c|c|c|c|}
\hline \multirow[t]{2}{*}{ Seeded Species } & \multirow[t]{2}{*}{ Common Name } & \multicolumn{2}{|c|}{$\begin{array}{l}\text { Hand vs. Mechanical } \\
\text { Density (plants } / \mathrm{m}^{2} \text { ) }\end{array}$} & \multicolumn{2}{|c|}{$\begin{array}{l}\text { Hand vs. Mechanical } \\
\text { Density (plants } / \mathrm{m}^{2} \text { ) }\end{array}$} \\
\hline & & 2003 & 2003 & 2004 & 2004 \\
\hline \multicolumn{6}{|l|}{ Shrubs } \\
\hline Artemisia nova & Black sagebrush & 0 & 0 & 0.21 & 0.78 \\
\hline Atriplex canescens & Fourwing saltbush & 0 & 0 & 0 & 0.01 \\
\hline Chrysothamnus viscidiflorus & Rabbitbrush & 0 & 0 & 0.04 & 0.10 \\
\hline Coleogyne ramosissima & Blackbrush & 0.01 & 0.01 & 0.16 & 0.24 \\
\hline Ephedra viridis & Mormon tea & 0 & 0 & 0 & 0 \\
\hline Ericameria nauseosa & Rubber rabbitbrush & 0.13 & 0.02 & 0.13 & 0.04 \\
\hline \multicolumn{6}{|l|}{ Grasses } \\
\hline Achnatherum hymenoides & Indian ricegrass & 0.01 & 0.01 & 0 & 0.07 \\
\hline Elymus elymoides & Bottlebrush squirreltail & 0.03 & 0.05 & 0 & 0.04 \\
\hline Poa secunda & Sandberg's bluegrass & 0.01 & 0.02 & 0 & 0 \\
\hline Pleuraphis jamesii & Galleta grass & 0 & 0 & 0 & 0 \\
\hline \multicolumn{6}{|l|}{ Forbs } \\
\hline Linum lewisii & Blue flax & 0.04 & 0.09 & 0.24 & 0.68 \\
\hline Eschscholzia californica & California poppy & 0.04 & 0.09 & 0 & 0 \\
\hline Penstemon eatonii & Eaton's penstemon & 0 & 0 & 0.18 & 0.36 \\
\hline Penstemon palmeria & Palmer's penstemon & 0 & 0 & 0 & 0.07 \\
\hline \multirow[t]{2}{*}{ Sphaeralcea grossulariifolia ${ }^{a}$} & $\begin{array}{l}\text { Gooseberry leaf } \\
\text { Globemallow }\end{array}$ & 0 & 0 & 0 & 0.07 \\
\hline & tal Perennial Species & 0.27 & 0.29 & 0.96 & 2.38 \\
\hline
\end{tabular}

\footnotetext{
${ }^{a}$ Not included in seed mix
}

The objective of this year's effort was not to sample the sites, but to identify those sites that could be sampled in future years. The majority of the sites are located in the Yucca Lake basin of the NTS (Figure 6-7). Fifteen of the sites were found and it was determined that varying degrees of information could be obtained by sampling the sites (Table 6-3). Three of the 28 sites were not located. The other ten were located but did not provide any information related to reclamation practices on the NTS (Table 6-4). At nine of the ten sites, no plants were found nor was there any sign that anything had been done at the sites. The other sites had been covered during activities at the site. The fifteen sites will be monitored in future years as time and funding allows.

Information gleaned from the monitoring effort will further refine the reclamation techniques that have been used on the NTS. 


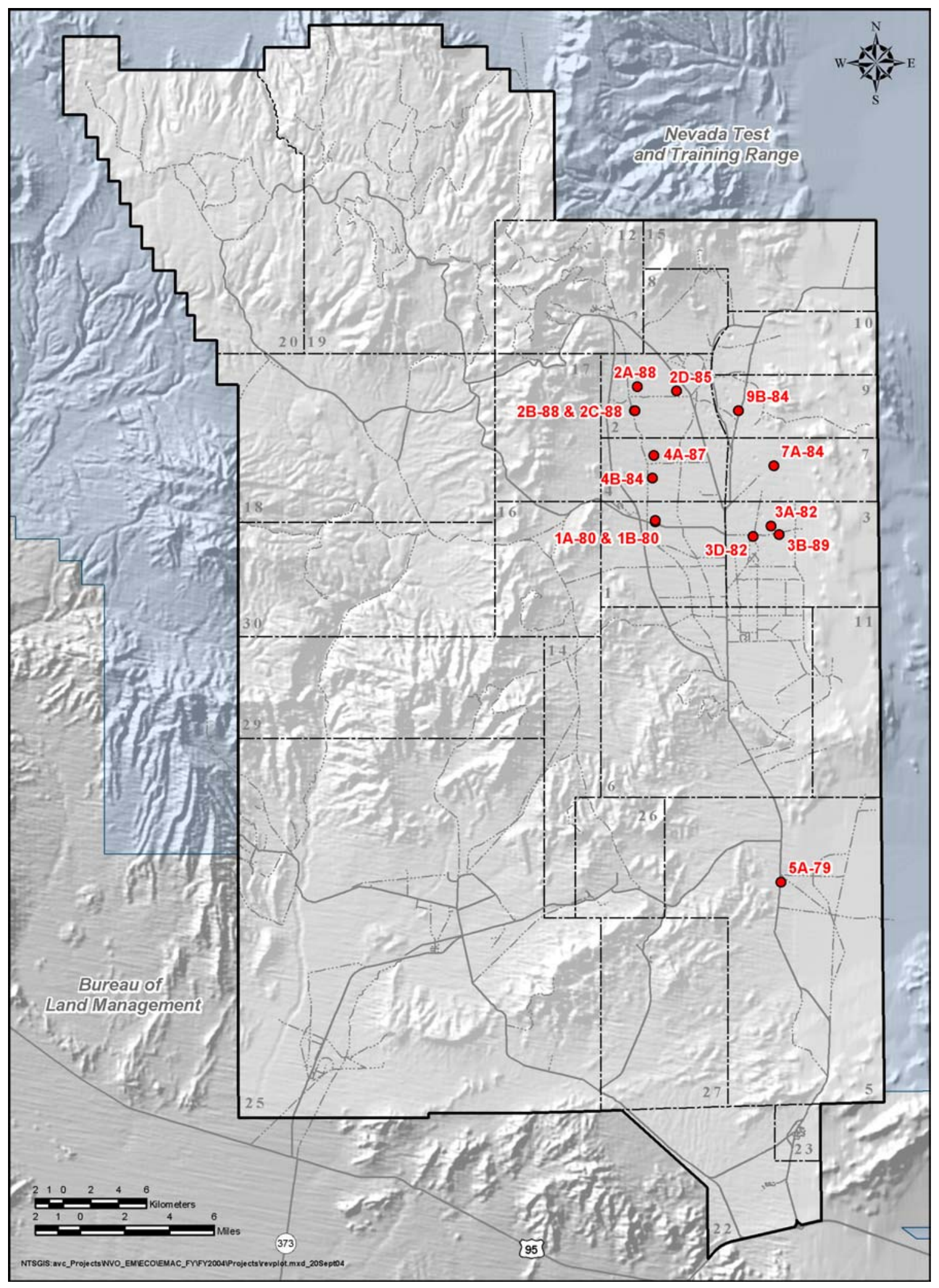

Figure 6-7. Location of historical revegetation sites on the NTS. 
Table 6-3. Historical revegetation sites located in 2004 to be sampled in future years.

\begin{tabular}{|c|c|c|c|c|c|}
\hline Site & Location & Species Planted & $\begin{array}{c}\text { Date } \\
\text { Revegetated }\end{array}$ & Comments & Status 2004 \\
\hline $1 \mathrm{~A}-80$ & $\begin{array}{l}\text { Area 1, Yucca } \\
\text { Flat piedmont }\end{array}$ & ATCA & $\begin{array}{c}\text { Aug/Sept } \\
1980\end{array}$ & & $\begin{array}{l}\text { Need RAD clearance to enter site, fence down in many places, Plants } \\
\text { present }\end{array}$ \\
\hline 1B-80 & $\begin{array}{l}\text { Area 1, Yucca } \\
\text { Flat piedmont }\end{array}$ & ATCA & $1980-81$ & & $\begin{array}{l}\text { Need RAD clearance to enter site, fence down in many places, Plants } \\
\text { present }\end{array}$ \\
\hline $2 \mathrm{~A}-88$ & $\begin{array}{l}\text { Area 2, Yucca } \\
\text { Flat piedmont }\end{array}$ & ATCA & 1988 & $\begin{array}{l}\text { Broadcast seed experiment, ATCA } \\
\text { germinated/survived }\end{array}$ & ATCA abundant, fencing still good, area was ripped, fenced \\
\hline 2B-88 & $\begin{array}{l}\text { Area 2, Yucca } \\
\text { Flat piedmont }\end{array}$ & ATCA & Nov. 28,1988 & $\begin{array}{l}\text { Broadcast seed experiment, ATCA } \\
\text { germinated/survived }\end{array}$ & $\begin{array}{l}\text { Not as many ATCA as at } 2 \mathrm{~A} \text {, more ERNA, appears to be a duplicate } \\
\text { of } 2 \mathrm{~A} \text {, area was ripped, fenced }\end{array}$ \\
\hline $2 \mathrm{C}-88$ & $\begin{array}{l}\text { Area 2, Yucca } \\
\text { Flat }\end{array}$ & $\begin{array}{l}\text { ATPO, ATCA, } \\
\text { LATR }\end{array}$ & Nov. 1988 & Located directly east of plot 2B & $\begin{array}{l}\text { Possible transplants, ripped, fenced, larger plot, maybe 2-3 times size } \\
\text { of } 2 B\end{array}$ \\
\hline 2D-85 & $\begin{array}{l}\text { Area 2, Yucca } \\
\text { Flat piedmont }\end{array}$ & ATCA & 1985 & SW corner, ATCA alive, ERNA & $\begin{array}{l}\text { On old pad directly west of crater, access- } 0.6 \text { miles west on } 02-04 \\
\text { off of Rainer Mesa Rd }\end{array}$ \\
\hline $3 \mathrm{~A}-82$ & $\begin{array}{l}\text { Area 3, Yucca } \\
\text { Flat }\end{array}$ & ATPO, LATR & $1982-84$ & $\begin{array}{l}\text { Density survival experiments in } \\
\text { clusters of } 5 \text { plants }\end{array}$ & $\begin{array}{l}\text { Fence semi-intact, } 16+\text { ATPO inside fence, } 11 \text { LATR inside fence, } 2 \\
\text { LATR outside, numerous ATPO outside of plot }\end{array}$ \\
\hline 3B-89 & $\begin{array}{l}\text { Area 3, Yucca } \\
\text { Flat }\end{array}$ & $\begin{array}{l}\text { ATCA, LATR, } \\
\text { HYSA }\end{array}$ & $1989-91$ & $\begin{array}{l}9 \text { acre site, moderate to good survival- } \\
\text { cover }\end{array}$ & $\begin{array}{l}\text { Looks very good, ATCA, KRLA, LYAN, some LATR \& ACHY, } \\
\text { ATCA becoming decadent, close to the YUFO } 12 \text { Site }\end{array}$ \\
\hline 3B-89 & $\begin{array}{l}\text { Area 3, Yucca } \\
\text { Flat }\end{array}$ & ATCA & $1989-91$ & Circular plot & ATCA shows some sign of life, green growth $<10 \%$ of plant \\
\hline $3 \mathrm{D}-82$ & $\begin{array}{l}\text { Area 3, Yucca } \\
\text { Flat }\end{array}$ & $\begin{array}{l}\text { ATCA, LATR, } \\
\text { ATPO }\end{array}$ & $1982-83$ & & $\begin{array}{l}\text { URA, west of road to area } 3 \text { from Uaxbl, first road to south off of } \\
3-03 \text { rd after Uaxbl facility }\end{array}$ \\
\hline $4 \mathrm{~A}-87$ & $\begin{array}{l}\text { Area 4, Yucca } \\
\text { Flat piedmont }\end{array}$ & ATCA, ARTR & 1987 & Sagebrush transplants & $\begin{array}{l}600 \mathrm{~m} \text { east of Orange Rd, } 600 \mathrm{~m} \mathrm{~N} \text { of } 404 \mathrm{Rd} \text {, lots of ATCA, fair to } \\
\text { poor condition, no ARTR located }\end{array}$ \\
\hline 4B-84 & $\begin{array}{l}\text { Area } 4 \text {, Yucca } \\
\text { Flat piedmont }\end{array}$ & $\begin{array}{l}\text { ATCA, LATR, } \\
\text { LYAN }\end{array}$ & 1984 & Lycium crown sprouts fenced & 6-10 ATCA dead, 6 LATR found, one old dead LYAN observed \\
\hline $7 \mathrm{~A}-84$ & $\begin{array}{l}\text { Area } 7 \text {, Yucca } \\
\text { Flat }\end{array}$ & LATR, ARTR & 1984 & $\begin{array}{l}\text { Sagebrush seedlings produced from } \\
\text { parent plants }\end{array}$ & LATR, ARTR alive, PRFA, YUBA, and ERNA \\
\hline 9B-84 & $\begin{array}{l}\text { Area 9, Yucca } \\
\text { Flat }\end{array}$ & LATR, ATCA & $1884-85$ & $\begin{array}{l}2 \text { cement pads with plants planted } \\
\text { nearby }\end{array}$ & In contamination area, only ATCA alive \\
\hline $5 \mathrm{~A}-79$ & $\begin{array}{l}\text { Area 5, } \\
\text { Frenchman Flat }\end{array}$ & LATR & $1979-80$ & $\begin{array}{l}\text { Seedling survival/rabbit exclosure } \\
\text { fencelets }\end{array}$ & LATR still looks good \\
\hline
\end{tabular}


Table 6-4. Historical revegetation sites not located in 2004, or found to have been disturbed and not to be sampled in future years.

\begin{tabular}{|c|c|c|c|c|c|}
\hline Site & Location & $\begin{array}{l}\text { Species } \\
\text { Planted }\end{array}$ & $\begin{array}{c}\text { Date } \\
\text { Revegetated }\end{array}$ & Comments & Status 2004 \\
\hline $1 \mathrm{C}$ & $\begin{array}{l}\text { Area 1, Yucca } \\
\text { Flat piedmont }\end{array}$ & ATCA & $1982-83$ & Poor survival, rodents dug up many plants & No sign of fencing or plants \\
\hline $3 \mathrm{C}$ & $\begin{array}{l}\text { Area 3, Yucca } \\
\text { Flat }\end{array}$ & $\begin{array}{l}\text { ATCA, } \\
\text { LATR, } \\
\text { ATPO }\end{array}$ & $1982-83$ & & No sign of fencing or plants \\
\hline 7DOD & $\begin{array}{l}\text { Area } 7, \text { Yucca } \\
\text { Flat }\end{array}$ & ATCA & 1983 & Poor establishment and survival because of Caliche & $\begin{array}{l}\text { No sign of disturbance in any direction for } \\
1000 \mathrm{~m} \text {, in middle of CORA/EPNE }\end{array}$ \\
\hline $3 \mathrm{E}$ & $\begin{array}{l}\text { Area 3, Yucca } \\
\text { Flat }\end{array}$ & & 1982 & On reveg map, cluster of sites around $\mathrm{U} 3 \mathrm{ax} / \mathrm{bl}$ & No sign of fencing or plants \\
\hline 9A & $\begin{array}{l}\text { Area 2, N- } \\
\text { Yucca flat }\end{array}$ & & Unknown & On reveg map, marked as suitable for reveg & No indication that anything was ever done \\
\hline $9 \mathrm{C}$ & $\begin{array}{l}\text { Area 2, N- } \\
\text { Yucca flat }\end{array}$ & & 1982 & On reveg map & No indication that anything was ever done \\
\hline BERM & $\begin{array}{l}\text { Area 5, } \\
\text { RWMS }\end{array}$ & & 1981 & On reveg map & No sign of fencing or plants \\
\hline $\mathrm{T} 2$ & $\begin{array}{l}\text { Area 5, } \\
\text { RWMS }\end{array}$ & & 1979 & On reveg map, seeded Jan/Feb. '89? & No sign of fencing or plants \\
\hline T4 & $\begin{array}{l}\text { Area 5, } \\
\text { RWMS }\end{array}$ & & 1980 & On reveg map & No sign of fencing or plants \\
\hline
\end{tabular}


THIS PAGE IS INTENTIONALLY LEFT BLANK 


\subsection{MONITORING OF THE HAZMAT SPILL CENTER}

\subsection{Task Description}

Biological monitoring at the Hazardous Materials Spill Center (HSC) on the playa of Frenchman Lake in Area 5 will be performed, if necessary, for certain types of chemical releases as per the center's programmatic Environmental Assessment. In addition, ESHD has requested that BN monitor any test which may impact plants or animals downwind which are off the playa. A document titled Biological Monitoring Plan for Hazardous Materials Testing at the Liquefied Gaseous Fuels Spill Test Facility on the Nevada Test Site was prepared in FY 1996 (BN, 1996). It describes how field surveys will be conducted to determine test impacts on plants and animals and to verify that the center's program complies with pertinent state and federal environmental protection legislation. The design of the monitoring plan calls for the establishment of three control transects and three treatment transects at three distances from the chemical release point. The control and treatment transects have similar environmental and vegetation characteristics.

BN biologists are tasked to review chemical release test plans to determine if field monitoring along the treatment transects is required for each test as per the monitoring plan criteria. All test-specific field monitoring is funded through the HAZMAT Spill Center. Since 1996, the majority of chemical releases being studied at the center use such small quantities that downwind test-specific monitoring has not been necessary.

\subsection{Task Progress Summary}

BN reviewed chemical spill test plans for the following three activities this year: Divine Invader 53-54, Rattler, and Roadrunner III. Chemicals were released at such low volumes or low toxicity that there was no need to monitor downwind transects for biological impacts. Baseline monitoring was conducted at established control-treatment transects near the HSC in May and September. This sampling noted the condition of plants and the presence of wildlife sign during the period of vegetative growth and summer drought, respectively. No differences in biota were noted along downwind (treatment) versus upwind (control) transects. Baseline monitoring data are collected to document any cumulative impacts over time of test center activities on biota downwind of the facility. These data are made available to neighboring land managers upon request. Noticeable cumulative impacts on biota are not expected. 
THIS PAGE IS INTENTIONALLY LEFT BLANK 


\subsection{LITERATURE CITED}

Altenbach, J.S., W. Amy, P.V. Bradley, P.E. Brown, K. Dewberry, D.B. Hall, J. Jeffers, B. Lund, J.E. Newmark, J.J. O'Farrell, M. Rahn, R.E. Sherwin, C.R. Tomlinson, J.A. Williams. 2002. Nevada Bat Conservation Plan. Nevada Bat Working Group. June 21, 2002. Austin, Nevada. 188 pp.

Bechtel Nevada, 1996. Biological Monitoring Plan for Hazardous Materials Testing at the Liquefied Gaseous Fuels Spill Test Facility on the Nevada Test Site. Submitted to U.S. Department of Energy, Nevada Operations Office, Letter from J. R. Kannard to R. C. Furlow, Correspondence No. E100-JRK-96-004, January 25, 1996.

— 2001. Adaptive Management Plan for Sensitive Plant Species on the Nevada Test Site. DOE/NV/11718-507, Bechtel Nevada, Las Vegas, NV, March 2001.

— 2002. Nevada Test Site Wildland Fire Management Plan, Revision 0, March 11, 2002. Submitted by letter to T. Wallace, NNSA/NSO from T. Habermas, BN, Correspondence No. A400-TH-02-0005, March 27, 2002.

Blomquist, K. W., C. A. Wills, W. K. Ostler, K. R. Rautenstrauch and T. P. O'Farrell, 1992. Distribution, Life History, Management, and Current Status of Astragalus beatleyae on the U.S. Department of Energy's Nevada Test Site. EGG10617-2187, EG\&G Energy Measurements, Santa Barbara Operations, Goleta, California, November 1992.

Blomquist, K. W., T. A. Lindemann, G. E. Lyon, D. C. Steen, C. A. Wills, S. A. Flick, and W. K. Ostler, 1995. Current Distribution, Habitat, and Status of Category 2 Candidate Plant Species on and Near the U.S. Department of Energy's Nevada Test Site. EGG11265-1149, EG\&G Energy Measurements, Las Vegas, Nevada, December 1995.

BN, see Bechtel Nevada.

DOE, see U.S. Department of Energy

DOE/NV, see U.S. Department of Energy Nevada Operations Office.

FWS, see U.S. Fish and Wildlife Service.

Greger, P. D. and E. M. Romney, 1994. Trends in Wildlife Utilization of Water Source and Adjacent Habitats at the Nevada Test Site 1989-91. In: Status of the Flora and Fauna on the Nevada Test Site 1989-91. Compiled by R. B. Hunter, DOE/NV/11432-57, Reynolds Electrical \& Engineering Co., Inc., Las Vegas, Nevada.

Greger, P. D. and E. M. Romney, 1999. High foal mortality limits growth of a desert feral horse population in Nevada. Great Basin Naturalist 59:374-379.

Hansen, D.J., P. D. Greger, C.A. Wills. 1997. Nevada Test Site Wetlands Assessment. DOE/NV/11718-124, Bechtel Nevada, Ecological Services, Las Vegas, Nevada. 
Hansen, Dennis J. and W. Kent Ostler. 2004. A survey of vegetation and wildland fire hazards on the Nevada Test Site. DOE/NV/11718-981. September 2004. Bechtel Nevada, Ecological Services, Las Vegas, Nevada.

Hunter, R. B., E. M. Romney, and A. Wallace, 1980. Fencing enhances shrub survival and growth for Mojave Desert revegetation. Great Basin Naturalist Memoirs No. 4:212-215.

Hunter, R. B., E. M. Romney, and A. Wallace, 1987. Revegetation on disturbed desert land at NUWAX and SEDAN. In: The Dynamics of Transuranics and Other Radionuclides in Natural Environments. Howard, W. A., and R. G. Fuller (Eds.). U.S. Department of Energy, Nevada Operations Office, Las Vegas, Nevada. NVO-272, pp. 79-97.

NNSA/NV, see U.S. Department of Energy, National Nuclear Security Administration Nevada Operations Office.

Ostler, W.K., D. J. Hansen, D.C. Anderson and D.B. Hall, 2000. Classification of Vegetation on the Nevada Test Site. DOE/NV/11718--477, Bechtel Nevada Ecological Services, Las Vegas, Nevada.

Peterson, F.F., 1981. Landforms of the Basin \& Range Province Defined for Soil Survey. Technical Bulletin 28, Nevada Agricultural Experiment Station, University of Nevada Reno, January 1981.

Romney, E. M., A. Wallace, and R. B. Hunter, 1989. Transplanting of native shrubs on disturbed land in the Mojave Desert, pp. 50-53. In: Proceedings of the Symposium on Shrub Ecophysiology and Biotechnology; 1987 June 30 - July 2: Logan, UT. Wallace, A., E. D. McArther, and M. R. Haferkamp (Compilers). General Technical Report INT-256, U.S. Department of Agriculture, Forest Service, Intermountain Research Station, Ogden, Utah.

U.S. Department of Energy. 2002a. A Graded Approach for Evaluating Radiation Doses to Aquatic and Terrestrial Biota, DOE-STD-1153-2002, U.S. Department of Energy, Washington, D.C.

U.S. Department of Energy. 2002b. Nevada Test Site Orthophoto Site Atlas. DOE/NV/11718-604. Geographic Information Systems Section, Remote Sensing Department, Bechtel Nevada, Las Vegas, Nevada.

U.S. Department of Energy Nevada Operations Office, 1996. Final Environmental Impact Statement for the Nevada Test Site and Off-Site Locations in the State of Nevada, Volume 1, Chapters 1-9. DOE/EIS 0243, Las Vegas, Nevada, August 1996. , 1998. Nevada Test Site Resource Management Plan, DOE/NV-518, Las Vegas, NV, December 1998.

, Undated (about 1995). Nevada Test Site Grid Map. ER\&NP Division, EG\&G Energy Measurements, Inc., Las Vegas, Nevada.

U.S. Fish and Wildlife Service, 1996. Final Programmatic Biological Opinion for Nevada Test Site Activities. File No. 1-5-96-F-33, August 22, 1996, Reno, Nevada. 
Wallace, A. and E. M. Romney, 1977. Initial land reclamation procedures related to possible Pu-cleanup activities at the Tonopah Test Range. In: Environmental Plutonium on the Nevada Test Site and Environs. White, M. G., P. B. Dunaway, and W. A. Howard (Eds.). NVO-171, Nevada Applied Ecology Group, U.S. Energy Research \& Development Administration, Las Vegas, Nevada, pp. $65-77$.

Wallace, A and E. M. Romney, 1980. The role of pioneer species in revegetation of disturbed desert areas. Great Basin Naturalist Memoirs 4:31-33.

Wallace, A., E. M. Romney, and R. B. Hunter, 1980. The challenge of a desert: revegetation of disturbed desert lands. Great Basin Naturalist Memoirs 4:216-225.

Western Bat Working Group. 1998. Western Bat Species: Regional Priority Matrix. Western Bat Working Group Workshop, February 9-13, 1998, Reno, Nevada, 4 pp. 
THIS PAGE IS INTENTIONALLY LEFT BLANK 


\section{DISTRIBUTION}

U.S. Department of Energy,

National Nuclear Security Administration

Nevada Site Office

Technical Library

P.O. Box $98518, \mathrm{M} / \mathrm{S} 505$

Las Vegas, NV 89193-8518

U.S. Department of Energy,

National Nuclear Security Administration

Nevada Site Office

Public Reading Facility

c/o Nuclear Testing Archive

P.O. Box 98521, M/S 400

Las Vegas, NV 89193-8521

U.S. Department of Energy,

Office of Scientific and Technical Information

P.O. Box 62

Oak Ridge, TN 37831-0062

Manager, Northern Nevada FFACO

Public Reading Facility

c/o Nevada State Library \& Archives
1 copy (uncontrolled)

1 copy (uncontrolled)

1 electronic copy (uncontrolled)

1 electronic copy (uncontrolled) 